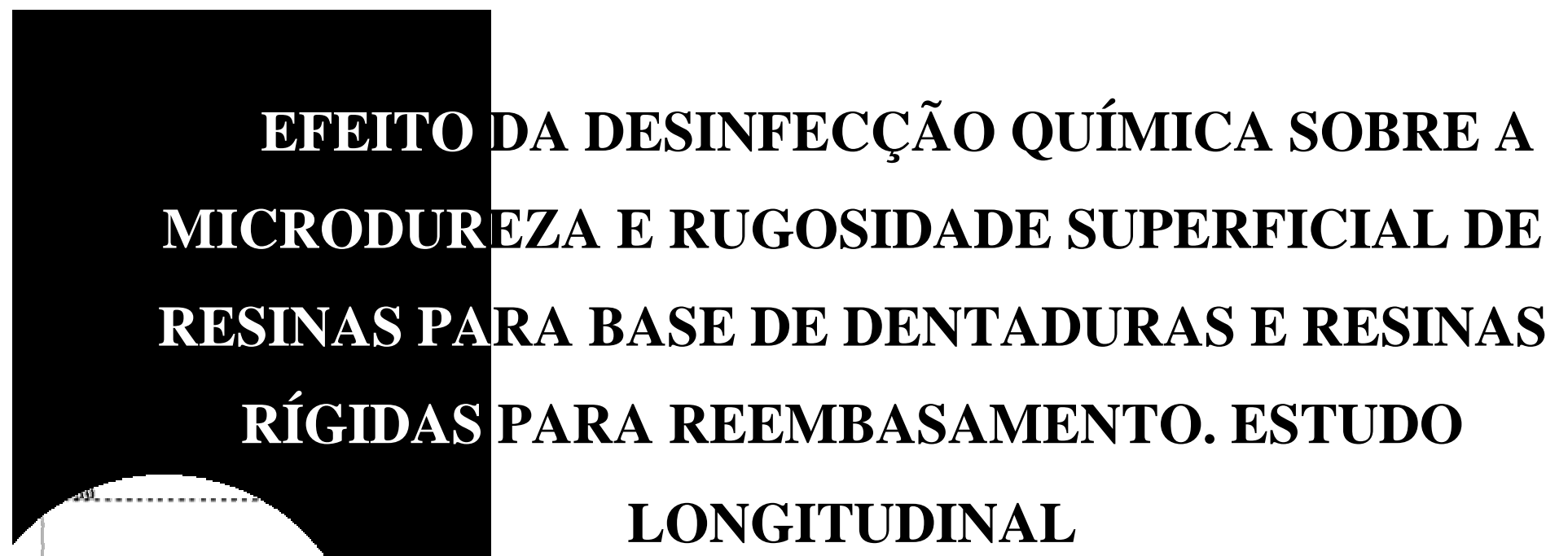

LUCIANA DE REZENDE PINTO

Dissertação apresentada à Faculdade de Odontologia de Bauru, Universidade de São Paulo, como parte dos requisitos para obtenção do título de Mestre em Odontologia, na área de Reabilitação Oral. 



\section{EFEITO DA DESINFECÇÃO QUÍMICA SOBRE A MICRODUREZA E RUGOSIDADE SUPERFICIAL DE RESINAS \\ PARA BASE DE DENTADURAS E RESINAS RÍGIDAS PARA \\ REEMBASAMENTO. ESTUDO LONGITUDINAL}

\section{LUCIANA DE REZENDE PINTO}

Dissertação apresentada à Faculdade de Odontologia de Bauru, da Universidade de São Paulo, como parte dos requisitos para obtenção do título de Mestre em Reabilitação Oral.

Orientador: Prof. Dr. Vinícius Carvalho Porto

BAURU 


\section{Pinto, Luciana de Rezende}

P658e Efeito da desinfecção química sobre a microdureza e rugosidade superficial de resinas para base de dentaduras e resinas rígidas para reembasamento. Estudo longitudinal. / Luciana de Rezende Pinto. - Bauru, 2007.

129p. ; il. ; 30 com.

Tese (Mestrado) - Faculdade de Odontologia de Bauru. Universidade de São Paulo.

Orientador - Prof. Dr. Vinícius Carvalho Porto

Autorizo, exclusivamente para fins acadêmicos e científicos, a reprodução total ou parcial desta dissertação/tese, por processos fotocopiadores e/ou meios eletrônicos.

Assinatura do Autor:

Data: 


\section{DADOS CURRICULARES}

\section{LUCIANA DE REZENDE PINTO}

20 de Abril de 1980

Nascimento na cidade de São José do Rio Preto - SP.

1998-2001

Graduação em Odontologia pela Faculdade de Odontologia de Araraquara - UNESP.

Especialização em Prótese Dentária 2002-2004 pelo Hospital de Reabilitação de Anomalias Craniofaciais - USP.

2005-2007

Pós Graduação em Reabilitação Oral em nível de Mestrado pela Faculdade de Odontologia de Bauru da Universidade de São Paulo (FOB-USP). 

"Esse é o destino do pensamento científico: estar em permanente mudança e reformulação. $\dot{E}$ um tanto desagradável ter de desdizer o que um dia já foi dito com grande ênfase. De outro lado, é fascinante sabermos que o conhecimento é inesgotável, que ainda há muito para aprender."

Flávio Gikovate 



\section{DEDICATÓRIA}

\section{$\mathcal{A} \mathcal{D} e u s$,}

Que, por estar iluminando meu caminho, me dá saúde, perseverança e coragem, para enfrentar todas as dificuldades e aprender com elas. É pela fé e amor em ti, que encontro forças para, a cada dia, me tornar uma pessoa melhor.

$\mathcal{A}$ ti dedico este trabalho! 



\section{AGRADECIMENTOS}

Aos meus pais, Vicente e Sílvia, por serem meus maiores incentivadores. Vocês são meus maiores exemplos de amor, respeito, caráter, dedicação e união. Obrigada por todo o apoio, carinho, zelo e confiança, fundamentais para que eu pudesse finalizar mais esta etapa de minha vida. Obrigada por estarem ao meu lado, sempre. Amo vocês.

Às minhas irmãs Fernanda e Daniela, por serem muito mais que irmãs, por serem verdadeiras amigas e companheiras. Obrigada pelas inúmeras conversas e telefonemas, algumas vezes cheios de lágrimas e gargalhadas. Obrigada pelo apoio técnico para a realização deste trabalho, pela confiança e principalmente pela amizade. Certamente, seria incompleta sem vocês.

À minha querida avó Neida, pelo carinho, respeito e compreensão. Obrigada por estar presente em todas as minhas conquistas e obrigada por ajudar-me a realizá-las sempre. A senhora é fundamental em minha vida.

Aos meus amigos, e já considerados irmãos, Thomas e Claudinei, por todo apoio durante esta etapa. Obrigada pela torcida e pensamentos positivos.

Ao Prof. Dr. Vinícius, Carvalho Porto, meu orientador, que com sua ousadia e determinação, tornou possível a realização deste trabalho. Muitas vezes suas idéias pareciam audaciosas demais, mas sua empolgação e inquietação sempre me motivaram a seguí-las, com entusiasmo e dedicação. Todas as dúvidas, conversas, discussões e dificuldades foram fundamentais para meu crescimento e desenvolvimento como cirurgiã-dentista e como aluna de pós-graduação. Obrigada por me ouvir, por confiar em mim e por tudo o que me ensinou e fez para o desenvolvimento deste trabalho. Você é mais do que um exemplo de professor que é completamente apaixonado pelo o que faz, você é uma pessoa admirável e um grande amigo. 
A todos os amigos da minha turma de Mestrado (Ana Paula, Dudu, Flora, Gabi, Rafael, Adriana, Daniel Bayardo, Valéria, Fernando, Paola, Daniel Castro, Buda, Romão e Thiago), por terem contribuído para um convívio divertido e prazeroso. Vocês serão sempre especiais em meu coração.

Agradeço especialmente à Flora, pelo apoio para o desenvolvimento deste trabalho.

Às amigas do curso de Doutorado (Paty, Katita, Lívia e Andréa), pelo companheirismo, alegria, entusiasmo e coragem. À vocês toda a minha admiração.

Às amigas de pós-graduação, Dafna, Angel, Paty, Kátia, Janine, Cecília, que são muito especiais. Obrigada por fazerem parte da minha vida aqui em Bauru. Com vocês compartilhei meus momentos de alegria, de tristeza, de dúvidas, de saudade. Muito obrigada pelas conversas, pela companhia, pela compreensão. Vocês são minha família aqui.

Aos amigos de pós-graduação, Ronan, Wagner, Renata Louro, Renata Cordeiro, Clarice, Vivi, Aline, Léo, Ismar, Fernando Orosco e Marcela Claudino, pela amizade e companheirismo durante todo o curso.

Á minha grande amiga peruana, Leslie, pela amizade, apoio, confiança e companheirismo, que a distância não conseguiu alterar. Obrigada por me permitir compartilhar com você minha vida e minha família. Você é muito querida por todos nós.

Ao nosso mais novo companheiro de pesquisa, Emílio, por toda ajuda, determinação, confiança, e compreensão. Sem sua ajuda e boa vontade, seria impossível concluir este trabalho com êxito. Você é mais um pilar que irá sustentar nosso grupo e ampliar nossa parceria em torno de algo maior: a pesquisa científica.

Aos meus amigos de graduação, que, mesmo à distância, me acompanham em todas as minhas conquistas, Jonas, Emi, Paty Aleixo, Roberta. Com vocês aprendi o verdadeiro sentido da amizade. Mesmo tomando caminhos diferentes, nosso carinho e 
preocupação um com os outros, não foram abalados. Agradeço todo o apoio, companheirismo, e solidariedade. Vocês foram importantíssimos para a minha formação, como profissional e como pessoa. Os admiro muito e os guardo em meu coração.

À Profa. Dra. Patrícia Petromilli Nordi Sasso Garcia, da Faculdade de Odontologia de Araraquara - UNESP, minha orientadora de Iniciação Científica, por ter despertado em mim o interesse pela pesquisa científica. Seu carinho e dedicação fizeram com que eu seguisse em frente para alcançar a pós-graduação. Foi sob sua orientação que vivenciei o verdadeiro sentido do que é ser professora. Você teve uma contribuição enorme para minha formação profissional e pessoal. Serei eterna admiradora de seu trabalho.

Ao Prof. José Fernando Scarelli Lopes e ao Prof. Dr. João Henrique Nogueira Pinto, do Hospital de Reabilitação de Anomalias Craniofaciais - USP, por me ensinarem muito sobre prótese dentária.

Ao Prof. Dr. Ricardo Marins de Carvalho, pela disposição em ajudar e pelos ensinamentos transmitidos.

Ao Prof. Dr. Claudinei da Cruz, pela ajuda na realização da análise estatística deste trabalho.

À Prof. Dra. Ana Paula Campanelli, do Departamento de Microbiologia da FOB-USP, por toda atenção e colaboração para a realização deste trabalho.

Aos professores do Departamento de Prótese Dentária da FOB-USP, Prof. Dr. Accácio Lins do Vale, Prof. Dr. Gerson Bonfante, Prof. Dr. Luiz Fernando Pegoraro, Prof. Dr. José Henrique Rubo, Prof. Dr. Milton Carlos Salvador, Prof. Dr. Carlos dos Reis Pereira de Araújo, Prof. Dr. Paulo Martins Ferreira e Prof. Dr. Wellington Cardoso Bonachela, por todos os ensinamentos transmitidos e pela contribuição no meu processo de aprendizado. 
À Faculdade de Odontologia de Bauru da Universidade de São Paulo, na pessoa do seu Diretor, Prof. Dr. Luiz Fernando Pegoraro, pela formação de uma comunidade cujo objetivo comum é a excelência.

Ao Departamento de Bioquímica da FOB-USP, representado pela Profa. Dra. Marília Rabelo Buzalaf, e ao Centro Integrado de Pesquisa da FOB-USP, representado pelo Prof. Dr. Vinícius Carvalho Porto, pelo empréstimo dos equipamentos para a realização deste trabalho.

Aos funcionários Ovídio e Telma (Departamento de Bioquímica), Neusa (Centro Integrado de Pesquisa), André e Cláudia (Departamento de Microbiologia), que zelaram de forma atenciosa para a realização deste trabalho e contribuíram com todo suporte técnico.

Aos alunos da graduação, Guilherme e Larissa, por terem colaborado para a execução deste trabalho.

À CNPq e à FAPESP, pelo auxílio financeiro concedido para a realização deste trabalho.

À todos que, ao longo deste período fizeram parte da minha vida. 


\section{SUMÁRIO}

LISTA DE FIGURAS

LISTA DE TABELAS

LISTA DE ABREVIATURAS E SÍMBOLOS

RESUMO

ABSTRACT

1. INTRODUÇÃ̃ E SÍNTESE BIBLIOGRÁFICA ......................................................33

1.1. Resinas acrílicas para confecção de bases para próteses totais .......................33

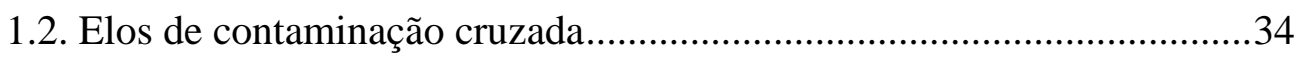

1.3. Controle da formação de biofilme microbiano na base da

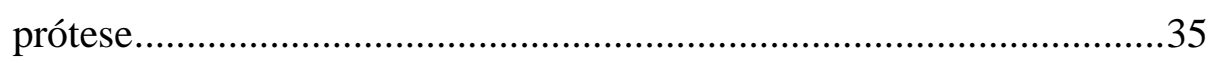

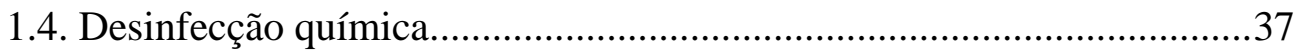

1.4.1. Tipos de desinfetantes .............................................................38

1.4.1.1. Compostos de amônia quaternária..........................38

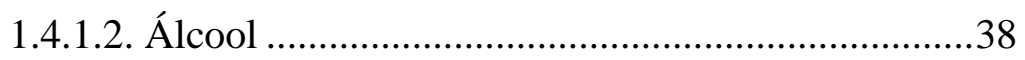

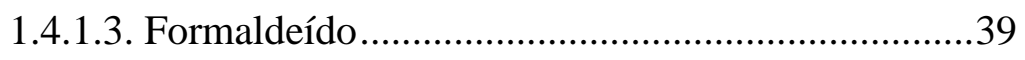

1.4.2. Desinfetantes químicos para uso em odontologia

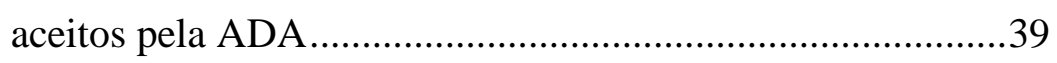

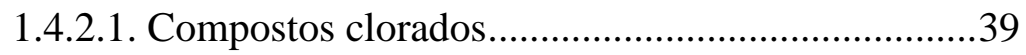

1.4.2.1.1. Ácido cloroso e dióxido de cloro................40

1.4.2.1.2. Hipoclorito de sódio ....................................40

1.4.2.2. Fenóis sintéticos ..........................................41

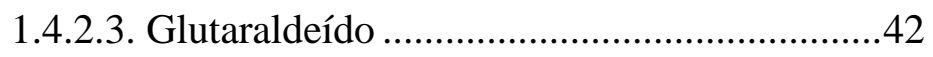

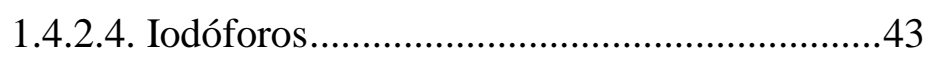

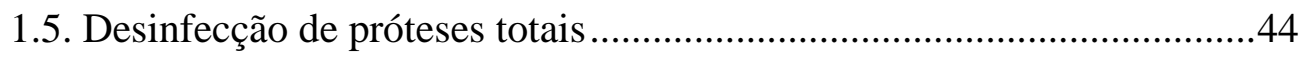

1.6. Efeitos adversos das soluções desinfetantes sobre as bases de prótese total . .46 
3. MATERIAL E MÉTODOS _............................................................................55

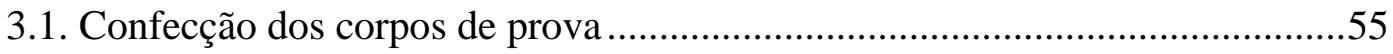

3.1.1. Confecção dos corpos de prova da resina

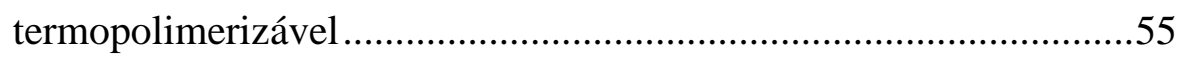

3.1.1.2. Confecção dos padrões de silicone para inclusão..................55

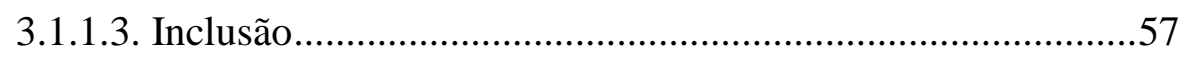

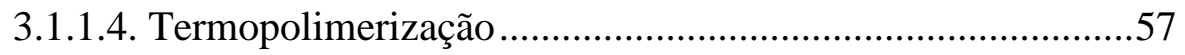

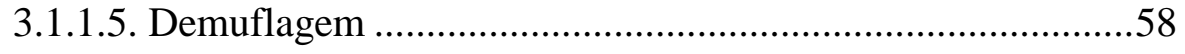

3.1.2. Confecção dos corpos de prova de resina autopolimerizável......................59

3.1.2.1. Confecção do molde em silicone laboratorial Zetalabor para inclusão.

3.1.2.2. Confecção dos corpos de prova das resinas autopolimerizáveis para reembasamento ..........................60

3.2. Planificação e polimento dos corpos de prova ...............................................61

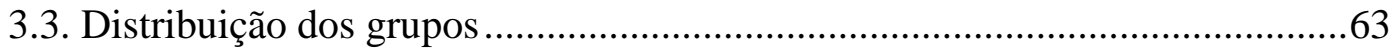

3.4. Identificação dos corpos de prova dentro de cada grupo................................64

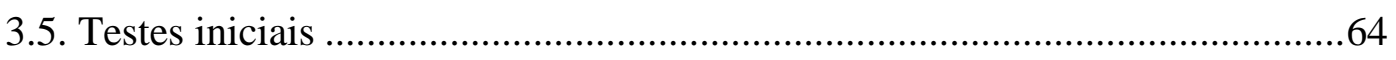

3.5.1. Análise da microdureza dos corpos de prova ...................................64

3.5.2. Análise da rugosidade superficial dos corpos de prova.......................66

3.6. Protocolo de desinfecção .......................................................................67

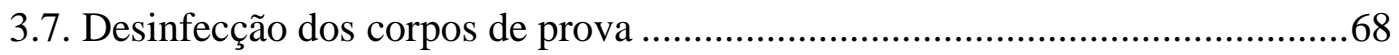

3.8. Armazenamento dos corpos de prova do grupo controle ...............................69

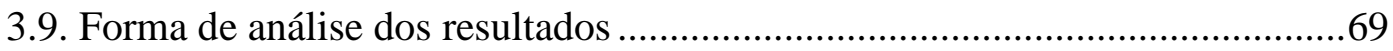

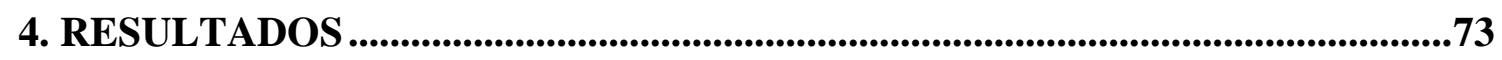

4.1. Análise da resina termopolimerizável …....................................................73

4.1.1. Análise do teste de microdureza .......................................................73

4.1.2. Análise do teste de rugosidade superficial ......................................76

4.2. Análise das resinas autopolimerizáveis ........................................................78

4.2.1. Análise do teste de microdureza da resina Jet ...................................78

4.2.2. Análise do teste de rugosidade superficial da resina Jet.....................82

4.2.3. Análise do teste de microdureza da resina Kooliner ..........................85 
4.2.4. Análise do teste de rugosidade superficial da resina

Kooliner.

4.2.5. Análise do teste de microdureza da resina Tokuyama

Rebase II fast .88

4.2.6. Análise do teste de rugosidade superficial da resina

Tokuyama Rebase II fast . .91

5. DISCUSSÃ

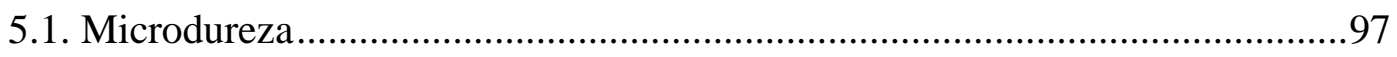

5.1.1. Resina Termopolimerizável..........................................................98

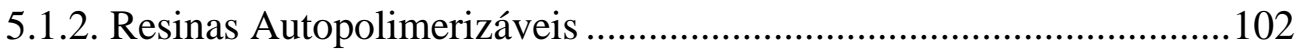

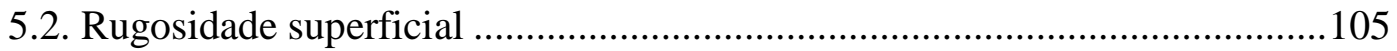

5.2.1. Resina Termopolimerizável...........................................................106

5.2.2. Resinas Autopolimerizáveis ............................................................ 108

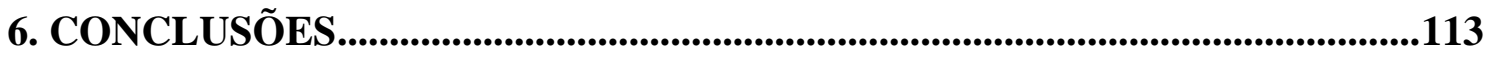

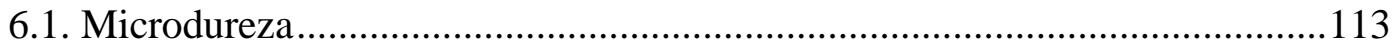

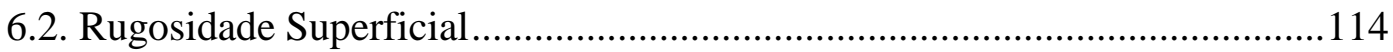

REFERÊNCIAS BIBLIOGRÁFICAS ....................................................................119 


\section{LISTA DE FIGURAS}

FIGURA 1 - Matriz plástica para confecção dos padrões em silicone.

FIGURA 2 - Prensagem do padrão de silicone

FIGURA 3 - Padrão de silicone pronto para ser incluído em mufla 56

FIGURA 4 - Polimerizadora microprocessada digital .58

FIGURA 5 - Demuflagem dos corpos de prova em resina 59

FIGURA 6 - Corpo de prova após remoção das rebarbas dos excessos de resina acrílica

FIGURA 7 - Politriz metalográfica manual 59

FIGURA 8 - Politriz metalográfica mecânica

FIGURA 9 - Conjunto de lixas e feltro para polimento

FIGURA 10 - Microdurômetro .64

FIGURA 11 - Imagem de uma compressão realizada para avaliação de microdureza em aumento de $10 \mathrm{X}$

FIGURA 12 - Rugosímetro .66

FIGURA 13 - Média aritmética e desvio padrão dos valores de microdureza (KHN) da resina Lucitone 550 para cada solução estudada, nos diferentes intervalos de avaliação 
FIGURA 14 - Média aritmética e desvio padrão dos valores de rugosidade superficial $(\mu \mathrm{m})$ da resina Lucitone 550, para cada solução estudada, nos diferentes intervalos de avaliação

FIGURA 15 - Média aritmética e desvio padrão dos valores de microdureza (KHN) da resina Jet, para cada solução estudada, nos diferentes intervalos de avaliação

FIGURA 16 - Média aritmética e desvio padrão dos valores de rugosidade superficial $(\mu \mathrm{m})$ da resina Jet, para cada solução estudada, nos diferentes intervalos de avaliação

FIGURA 17 - Média aritmética e desvio padrão dos valores de microdureza (KHN) da resina Kooliner, para cada solução estudada, nos diferentes intervalos de avaliação

FIGURA 18 - Média e desvio padrão dos valores de rugosidade superficial $(\mu \mathrm{m})$ da resina Kooliner, para cada solução estudada, nos diferentes intervalos de avaliação

FIGURA 19 - Média e desvio padrão dos valores de microdureza (KHN) da resina Tokuyama Rebase II fast, para cada solução estudada, nos diferentes intervalos de avaliação 88

FIGURA 20 - Média e desvio padrão dos valores de rugosidade superficial $(\mu \mathrm{m})$ da resina Tokuyama Rebase II fast, para cada solução estudada, nos diferentes intervalos de avaliação. 


\section{LISTA DE TABELAS}

TABELA 1 - Teste de Tukey dos valores médios e desvio padrão da microdureza $(\mathrm{KHN})$ da resina termopolimerizável Lucitone 550, nas diferentes soluções, em cada intervalo de avaliação

TABELA 2 - Teste de Tukey dos valores médios e desvio padrão da rugosidade superficial $(\mu \mathrm{m})$ da resina termopolimerizável Lucitone 550, nas diferentes soluções, em cada intervalo de avaliação

TABELA 3 - Teste de Tukey dos valores médios e desvio padrão da microdureza $(\mathrm{KHN})$ da resina autopolimerizável Jet, nas diferentes soluções, em cada intervalo de avaliação 80

TABELA 4 - Teste de Tukey dos valores médios e desvio padrão da rugosidade superficial $(\mu \mathrm{m})$ da resina termopolimerizável Jet, nas diferentes soluções, em cada intervalo de avaliação

TABELA 5 - Teste de Tukey dos valores médios e desvio padrão da microdureza $(\mathrm{KHN})$ da resina autopolimerizável Kooliner, nas diferentes soluções, em cada intervalo de avaliação

TABELA 6 - Média e desvio padrão dos valores de rugosidade superficial $(\mu \mathrm{m})$ da resina autopolimerizável Kooliner, nas diferentes soluções, em cada intervalo de avaliação . .88

TABELA 7 - Teste de Tukey dos valores médios e desvio padrão da microdureza $(\mathrm{KHN})$ da resina autopolimerizável Tokuyama Rebase II fast, de acordo com as diferentes soluções, em cada intervalo de avaliação 
TABELA 8 - Teste de Tukey dos valores médios e desvio padrão da rugosidade superficial $(\mu \mathrm{m})$ da resina autopolimerizável Tokuyama Rebase II fast, nas diferentes soluções, em cada intervalo de avaliação .92 


\section{LISTA DE ABREVIATURAS E SÍMBOLOS}

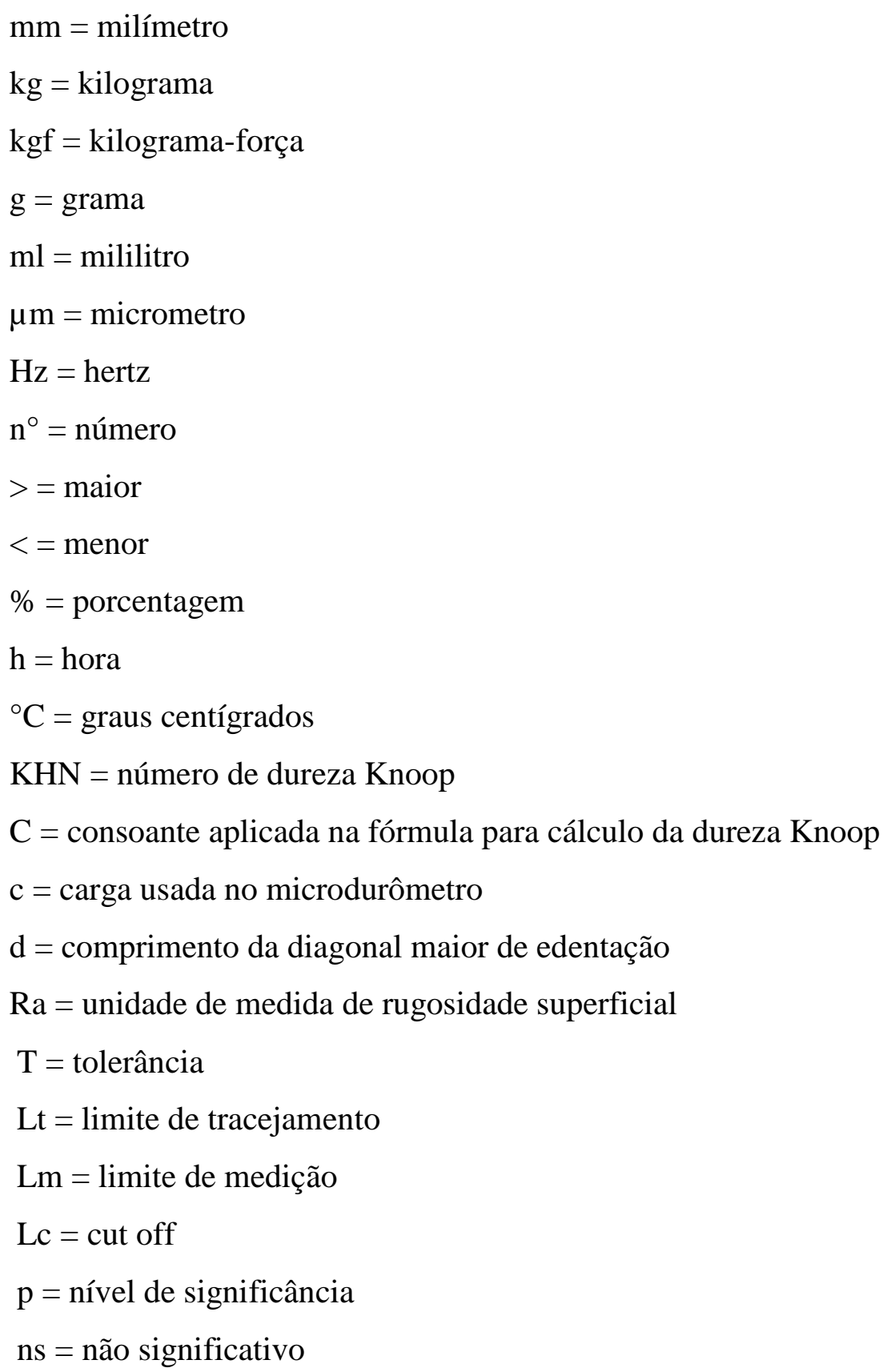


Resumo 



\section{RESUMO}

O objetivo deste estudo foi investigar, longitudinalmente, o efeito de cinco soluções desinfetantes sobre a microdureza e rugosidade superficial de uma resina acrílica termopolimerizável e três materiais reembasadores rígidos. Um total de 240 corpos de prova circulares $(30 \mathrm{X} 6 \mathrm{~mm})$ foram fabricados, utilizando um material para base de dentaduras (Lucitone 550; $\mathrm{n}=60$ ), e três materiais rígidos, para reembasamento (Jet; $n=60$, Kooliner; $n=60$, Tokuyama rebase II fast; $n=60$ ), os quais foram imersos em água (controle), e em cinco soluções desinfetantes (hipoclorito de sódio a 1\%, hipoclorito de sódio a $2 \%$, hipoclorito de sódio a 5,25\%, glutaraldeído a $2 \%$ e gluconato de clorexidina a 4\%), e testados para avaliação de microdureza Knoop (KHN) e rugosidade superficial $(\mathrm{Ra}-\mu \mathrm{m})$ em diferentes intervalos (antes das imersões, após 30, 90 e 180 ciclos de desinfecção. Em cada condição experimental foram utilizados 10 corpos de prova de cada material estudado. Os dados foram analisados através de esquema fatorial (6X4) e as médias foram analisadas por meio de análise de variância, seguida por teste de Tukey a 5\%. Para as resinas Lucitone $550(20,61 \pm 1,36$ a 15,44 \pm $1,26 \mathrm{KHN})$, Jet $(18,74 \pm 0,47$ a $13,75 \pm 0,95 \mathrm{KNH})$, Kooliner $(14,09 \pm 1,63$ a 7,52 \pm $0,88 \mathrm{KHN})$ e Tokuyama rebase II fast (12,57 $\pm 0,94$ a 8,28 \pm 0,39 KHN), foi observada uma diminuição significativa dos valores de microdureza, independente da solução utilizada, após 180 ciclos de imersão. Não foi observada interação significativa para a rugosidade da resina Kooliner. Para a resina Lucitone $550(0,06 \pm 0,01$ a 0,20 \pm $0,02 \mu \mathrm{m})$ e Jet $(0,07 \pm 0,01$ a $0,23 \pm 0,04 \mu \mathrm{m})$, foi observado aumento significativo dos valores de rugosidade superficial, independente da solução desinfetante utilizada, e a após 180 ciclos de imersão em água, estes materiais mantiveram valores semelhantes ao da avaliação inicial. A resina Tokuyama rebase II fast não mostrou diferenças significativas nos valores de rugosidade superficial quando imersa em água, hipoclorito de sódio a $2 \%, 5,25 \%$ e glutaraldeído a $2 \%$, durante o período do estudo. Ao final da avaliação (180 ciclos), conclui-se que, embora todas as soluções tenham causado redução da microdureza da resina Lucitone 550, os espécimes submetidos às imersões em $\mathrm{H} 5,25 \%$ e $\mathrm{H} 2 \%$ apresentaram menores valores, no entanto, não ocorreu diferença significante entre os desinfetantes para as resinas autopolimerizáveis. As soluções $\mathrm{H} 1 \%$, H2\% e GC4\% causaram maior alteração na rugosidade superficial da resina Lucitone 550. Estas mesmas soluções, além de $\mathrm{H} 5,25 \%$, promoveram maior rugosidade na resina 
Jet, enquanto que, para a resina Tokuyama Rebase II fast, não houve diferença entre os desinfetantes

Palavras-chave: Resinas acrílicas. Desinfecção 
Abstract 



\section{ABSTRACT \\ Effect of chemical disinfection on the hardness and roughness of denture base resins and hard chairside resins. A longitudinal study}

The aim of this study was to investigate the longitudinal effect of five disinfection solutions on the hardness and roughness of one heat-polymerizing denture base acrylic resin and three hard chairside resins. A total of 240 circular specimens (30 X $6 \mathrm{~mm}$ ) were fabricated using one denture base material (Lucitone 550; $\mathrm{n}=60$ ) and three hard chairside reliners (Jet; $n=60$, Kooliner; $n=60$, Tokuyama rebase II fast; $n=60$ ), which were immersed in water (control), and five disinfecting solutions (1\% sodium hypochlorite; $2 \%$ sodium hypochlorite; $5,25 \%$ sodium hypochlorite, $2 \%$ glutaraldehyde; $4 \%$ chlorhexidine gluconate) that were tested for knoop hardness (KHN) and roughness (Ra- $\mu \mathrm{m})$ for different times (before immersions, after 30, 90 and 180 immersion cycles). For each experimental condition, 10 specimens were used from each material. Data was analyzed by factorial scheme $(6 \times 4)$ and the means were analyzed by The Variance Analysis which was followed by Tukey's test 5\%. For Lucitone 550 (from 20,61 $\pm 1,36$ to $15,44 \pm 1,26 \mathrm{KHN}$ ), Jet (from $18,74 \pm 0,47$ to $13,75 \pm 0,95 \mathrm{KHN}$ ), Kooliner (from $14,09 \pm 1,63$ to $7,52 \pm 0,88 \mathrm{KHN}$ ), Tokuyama rebase II fast (from $12,57 \pm 0,94$ to 8,28 $\pm 0,39 \mathrm{KHN}$ ) significant decrease in hardness was observed regardless of the solution used, after 180 immersion cycles. No significant interactions were observed for Kooliner roughness. Between Lucitone (from 0,06 $\pm 0,01$ to $0,20 \pm 0,02 \mu \mathrm{m}$ ) and Jet, (from $0,07 \pm 0,01$ to $0,23 \pm 0,04 \mu \mathrm{m}$ ) there was a significant increase in roughness regardless of the disinfectant solution used; Jet showed significant increase in roughness after immersion in water for 180 cycles. Tokuyama rebase II fast showed no significant differences in roughness when immersed in water, $2 \%$ sodium hypochlorite, $5.25 \%$ sodium hypochlorite, and $2 \%$ glutaraldehyde after 180 cycles. In conclusion, this study showed that Lucitone 550 specimens exhibited significant decrease in hardness regardless of the disinfection solution used, and the specimens immersed in $\mathrm{H} 5,25 \%$ and H2\% showed lower hardness values; However, no significant differences were noted 
between all disinfectants solution, for hard chairside resins. The solutions $\mathrm{H} 1 \%, \mathrm{H} 2 \%$ and GC4\% caused more alteration in roughness of Lucitone 550. These solutions along with $\mathrm{H} 5,25 \%$ caused an increase in the roughness of Jet, while with the Tokuyama rebase II fast there was no difference between the disinfection solutions.

Keywords: Acrylic resins. Disinfection 


\section{Introdução}

e Síntese Bibliográfica 



\section{Introdução e Síntese Bibliográfica}

\subsection{Resinas acrílicas para confecção de bases para próteses totais}

Uma prótese total é constituída de uma base onde são montados os dentes artificiais. Essa base, além de suporte, é também responsável pela estabilidade, retenção e distribuição das forças mastigatórias ao rebordo subjacente. Por cerca de 80 anos, a borracha vulcanizada (vulcanite), patenteada por Nelson Goodyear em 1851, foi o material tecnicamente mais prático utilizado para a confecção desta base $\left(\operatorname{SEARS}^{96}, 1958\right)$. No entanto, apesar desse produto ser barato, durável, leve, de fácil confecção e com propriedades físicas adequadas, deixava a desejar em relação à estética por apresentar cor vermelho escura $\left(\operatorname{SEARS}^{96}, 1958\right)$.

Em 1936, a Vernon Benshoff Company lançou, experimentalmente, uma resina acrílica em forma de gel que viria, posteriormente, com o nome de Veronite. Em 1937, surgiu a resina acrílica nas formas de pó e líquido, com o nome de Crystolex (Kerr Dental Manufaturing Company) e, mais tarde, surgiu a resina Lucitone (L. D. Caulk Company) também nas formas de pó e líquido (SEARS ${ }^{96}$,1958). Um ano depois, a American Dental Association (ADA) testou e aprovou as propriedades físicas e mecânicas do polimetil metacrilato (PMMA), composição básica das resinas acrílicas. Juntamente com a aprovação do National Bureau of Standarts, o PMMA passou a fazer parte do contex to da odontologia (SEARS $\left.{ }^{96}, 1958\right)$.

As resinas acrílicas à base de PMMA apresentam uma combinação de características favoráveis, como facilidade da manipulação, estética satisfatória e bom desempenho clínico, as quais, associadas ao seu custo acessível, têm resultado em ampla utilização (JAGGER et al. ${ }^{48}$, 2001). Além disso, um outro aspecto favorável desse material é a possibilidade de realizar reembasamento das bases das próteses. Este procedimento visa restabelecer as condições de retenção, suporte e estabilidade, alteradas em função do processo contínuo de reabsorção do rebordo residual.

Algumas resinas acrílicas autopolimerizáveis têm sido desenvolvidas para a realização do reembasamento do tipo imediato, método mais rápido e de fácil execução que o reembasamento mediato, sendo freqüentemente utilizado para a readaptação das bases das próteses, sobretudo nos tratamentos de pacientes idosos, cujo número tem aumentado significativamente. Além disso, os materiais de reembasamento garantem procedimentos clínicos de baixo custo e promovem uma menor reação exotérmica, ou 
seja, liberam menor quantidade de calor durante sua manipulação (AZEVEDO et al. ${ }^{10}$, 2006).

Após a confecção de uma base para prótese total, ou mesmo após a realização de reembasamentos desta base, é necessário realizar ajustes e polimento a fim de promover uma melhor adaptação da prótese ao rebordo alveolar. Entretanto, tais procedimentos laboratoriais contribuem para a contaminação da prótese $\left(\mathrm{KATBERG}^{50}\right.$, 1974, KAHN; LANCASTER; KATE ${ }^{49}$, 1982).

\subsection{Elos de contaminação cruzada}

Grande atenção tem sido dada, desde a descoberta da AIDS, na década de 80, aos procedimentos de controle de infecção cruzada, tanto na área médica como na odontológica.

Durante a realização de uma reabilitação oral protética, várias etapas clínicas oferecem dificuldades para prevenção da contaminação cruzada (MERCHANT; MOLINARI $^{67}$, 1989). Segundo BRACE; PLUMER ${ }^{16}$, 1993, as próteses trazidas das clínicas para os laboratórios para ajustes e reparos contêm bactérias, vírus e fungos, colocando em risco a saúde dos técnicos em prótese dental se não forem corretamente desinfetadas. Em outro estudo, POWELL et al. ${ }^{86}, 1990$, constataram que $67 \%$ de todos os materiais enviados ao laboratório de prótese estavam infectados com vários graus de bactérias patógeno-oportunistas. Além disso, a presença de altos números de bactérias foi encontrada em pedra pomes de uso laboratorial, para polimento de próteses, quando não eram mantidas práticas de controle de higiene, esterilização e desinfecção nos laboratórios de prótese dentária (WILLIAMS et al. ${ }^{113}, 1985$ ). Desse modo, muitos microorganismos orais e não orais associados a doenças locais e sistêmicas têm sido cultivados a partir de próteses contaminadas, materiais e instrumentais de laboratório, tais como escovas de polimento, discos de feltro, brocas e pedras montadas (WAKEFIELD $^{108}$, 1980; WILLIANS et al. ${ }^{113}$, 1985; DEPAOLA et al. ${ }^{33}$, 1990), evidenciando a importância da desinfecção não apenas dos materiais enviados aos laboratórios, mas também das próteses vindas dos laboratórios para a clínica odontológica, principalmente as próteses totais imediatas que têm contato direto com o sangue do paciente (KING; MATTIS $\left.{ }^{52}, 1991\right)$. 


\subsection{Controle da formação de biofilme microbiano na base da prótese}

Se por um lado é imprescindível a realização de desinfecções de próteses para controle da infecção cruzada entre consultório e laboratório, por outro, é de extrema importância a realização de desinfecções, controladas pelo paciente, como método de higiene da prótese, visando ao controle do biofilme microbiano e conseqüentemente, à prevenção de doenças.

Muitos autores pesquisaram a composição e a formação do biofilme microbiano em bases de próteses de pacientes sadios e portadores de estomatite por uso de dentadura (THEILADE; BUDTZ - JORGENSEN ${ }^{104}, 1980$, BUDTZ - JORGENSEN et al. $^{21}$, 1981, THEILADE; BUDTZ - JORGENSEN; THEILADE ${ }^{103}, 1983$, BUDTZ JORGENSEN; THEILADE ${ }^{20}$, 1983, FRANK; STEUER ${ }^{38}$, 1985, CATALÁN; HERRERA; MARTINEZ ${ }^{22}$, 1987) e constataram que alguns microorganismos desse biofilme poderiam estar presentes tanto na superfície externa da base da prótese, quanto na interna, e também invadindo o tecido conjuntivo adjacente (CATALÁN; HERRERA; MARTINEZ ${ }^{22}$, 1987).

A colonização de microorganismos na base da prótese é facilitada, principalmente, pela degradação química do acrílico e por sua rugosidade superficial (YAMAUCHI et al. ${ }^{115}$, 1990, VERRAN; MARYAN ${ }^{107}$, 1997, RADFORD et al. ${ }^{89}$, 1998, RADFORD; CHALLACOMBE; WALTER ${ }^{88}$, 1999, NIKAWA et al. ${ }^{75}$, 2001, LAMFON et al. $\left.{ }^{55}, 2003\right)$.

Os processos de degradação química das resinas ocorrem pela ação de microorganismos orais que utilizam o carbono presente na estrutura química do metil metacrilato como fonte de nutrientes, contribuindo para o aumento da porosidade desse material (ENGELHARDT $\left.{ }^{37}, 1974\right)$. Já a rugosidade superficial é inerente às técnicas de acabamento e polimento, e seu valor $(\mathrm{Ra})$ varia de acordo com a técnica utilizada, tanto para resinas acrílicas termopolimerizáveis, quanto para as autopolimerizáveis. O polimento sempre promove uma redução dos valores de rugosidade superficial, (ULUSOY; ULUSOY; AYDIN ${ }^{105}$, 1986, LONEY; MOULDING ${ }^{60}$, 1993, LONEY et al., $1994^{61}$, SOFOU et al. $\left.{ }^{98}, 2001\right)$ e, embora esses valores não sejam tão claros na literatura, preconiza-se ser inferior a $0,2 \mu \mathrm{m}$ para dificultar a adesão microbiana (QUIRYNEN et al. ${ }^{87}, 1990$, BOLLEN; LAMBRECHTS; QUIRYNEN ${ }^{15}, 1997$ ).

Todavia, as técnicas convencionais de acabamento e polimento de bases de próteses totais dificilmente atingem níveis de rugosidade superficial inferiores a $0,2 \mu \mathrm{m}$ 
e mesmo em superfícies lisas, qualquer irregularidade no polimento já é suficiente para facilitar o acúmulo de microorganismos (VERRAN; MARYAN ${ }^{107}$, 1997). Dessa forma, as bases de próteses totais são potentes reservatórios de microorganismos, podendo atuar como foco de infecções orais (SARAMANAYAKE; McCOURTIE; Mac FARLANE $^{94}$, 1980, IACOPINO; WATHEN ${ }^{47}$, 1992, VERRAN; MARYAN ${ }^{107}, 1997$, NIKAWA; HAMADA; YAMAMOTO ${ }^{76}, 1998$, PIRES et al. $\left.{ }^{84}, 2002\right)$.

Sabe-se que o biofilme da prótese está intimamente relacionado com o desenvolvimento de patologias inflamatórias, como a estomatite por uso de dentadura, principalmente por conter em sua composição leveduras de Candida albicans. Para alguns autores, o biofilme da prótese, associado à presença de Candida albicans, é o principal fator etiológico desta doença (PIRES et al. ${ }^{84}$, 2002, BARBEAU et al. ${ }^{11}$, 2003).

Estudos de NIKAWA; HAMADA; YAMAMOTO ${ }^{76}$, 1998, e ARKEL; SHINNICK $^{7}, 2003$, verificaram outras patologias associadas ao biofilme da prótese. Segundo os autores, sua presença pode estar relacionada a infecções orais, gastrointestinais e pulmonares, principalmente em pacientes imunossuprimidos ou idosos, que fazem deglutição e aspiração contínua de microorganismos do biofilme da prótese.

Portanto, controlar a formação do biofilme microbiano na base da prótese é imprescindível para a manutenção da saúde. Isto deve ser promovido por meio de técnicas diárias de higienização e desinfecção das mesmas, realizadas pelo próprio paciente, orientado sempre pelo cirurgião - dentista. Essa rotina do regime de limpeza deve ter como objetivo remover e prevenir o acúmulo de biofilme microbiano, mucina, restos de alimentos, cálculo e coloração exógena (BUDTZ - JORGENSEN ${ }^{19}$, 1979).

Várias técnicas e produtos para higienização de próteses foram desenvolvidos no final dos anos 60 e na década de 70 (MACCALLUM et al. ${ }^{63}$, 1968) e grande parte dos trabalhos preconiza a combinação da remoção mecânica do biofilme, por meio de escovação da prótese com sabão neutro ou dentifrícios, com o uso de soluções químicas (BUDTZ - JORGENSEN ${ }^{19}$, 1979; ABELSON $^{3}, 1985$; DILLS et al. $^{35}, 1988$; CHAN et al. ${ }^{23}, 1991$; ODMAN ${ }^{78}, 1992$; LOMBARDI $^{59}$, 1993). Embora tais estudos comprovem a preferência do paciente pelo uso da escovação da prótese somente, os resultados afirmam que a limpeza mecânica sozinha não é suficiente para garantir a higienização adequada, e são contundentes na associação da técnica mecânica com produtos químicos para limpeza eficiente das próteses. 
A literatura aponta uma variedade de produtos químicos que podem ser utilizados para o controle da formação de biofilme microbiano sobre a base das próteses. Enquanto alguns autores destacam o uso de soluções higienizantes para diminuição da quantidade de microorganismos (GHALICHEBAF; GRASER; ZANDER $^{41}$, 1982; MOORE; SMITH; KENNY ${ }^{73}$, 1984; MINAGI; TSUNODA; YOSHIDA $^{68}$, 1987; CHAN et al. ${ }^{23}$, 1991; BASSON; QUICK; THOMAS ${ }^{12}$, 1992; GORNITSKY et al. ${ }^{43}, 2002$; GLASS et al. $\left.{ }^{42}, 2004\right)$, outros consideram que somente o uso de soluções químicas desinfetantes é capaz de eliminar microorganismos que invadem o interior do acrílico (CHAU et al. ${ }^{25}, 1995$, LIN et al. $\left.{ }^{58}, 1999\right)$.

\subsection{Desinfecção química}

A desinfecção provoca a destruição da maioria dos microorganismos patogênicos, sendo que a redução dos níveis de contaminação microbiana depende do desinfetante usado, concentração do mesmo, tempo de contato, espectro de atividade antimicrobiana, temperatura e reutilização. (AMERICAN DENTAL ASSOCIATION ${ }^{4}$, 1992, COUNCIL ON SCIENTIFIC AFFAIRS; COUNCIL ON DENTAL PRACTICE, $1996^{28}$, MERCHANT $\left.^{66}, 1997\right)$.

Os procedimentos de desinfecção podem ser realizados por meio de imersão do instrumento ou por spray de desinfetante aplicado sobre as superfícies. No entanto, sempre que possível, a imersão deve ser utilizada, pois esse método assegura a exposição de todas as superfícies do objeto pela substância química durante o período recomendado (MERCHANT ${ }^{66}, 1997$, MERCHANT; MOLINARI ${ }^{67}, 1989$ ).

Idealmente os desinfetantes químicos devem ter espectro antimicrobiano o mais amplo possível; ação rápida sobre formas vegetativas e esporos de bactérias e fungos, protozoários e vírus; não ser afetado por fatores físicos, tais como matéria orgânica (sangue, saliva), outros sabões, detergentes ou substâncias químicas; ser atóxicos aos tecidos; inodoros; econômicos; de fácil utilização; e ao mesmo tempo não promover alterações superficiais que causem danos ao objeto desinfetado (COTTONE; MOLINARI $^{27}$, 1987; MOLINARI et al. ${ }^{69}$, 1988, MOLINARI; MERCHANT; GLEASON $^{70}$, 1990; MOLINARI; RUNNELLS ${ }^{71}$, 1991, MOLINARI; SCHAEFER; RUNNELLS $^{72}$, 1996).

Obviamente, nenhum desinfetante disponível preenche todos os critérios de um desinfetante ideal (MOLINARI; RUNNELLS ${ }^{71}$, 1991, WHITACRE ${ }^{111}$, 1991). 
Deve-se considerar que a eficácia dos desinfetantes de superfície e de imersão depende de vários fatores: concentração e tipo de microorganismos, concentração da substância química, tempo de exposição, quantidade de resíduos orgânicos acumulados (MOLINARI; RUNNELLS ${ }^{71}$, 1991, RUTALA; WEBER ${ }^{92}$, 1997), natureza do objeto (se possui poros), e o pH da solução (RUTALA; WEBER $\left.{ }^{92}, 1997\right)$.

\subsubsection{Tipos de desinfetantes}

\subsubsection{Compostos de amônia quaternária}

Esses agentes atuam em nível de membrana plasmática das bactérias e fungos. A membrana citoplasmática é desorganizada à medida que o agente químico é absorvido, promovendo a perda do material intracelular. Em seguida, ocorre a degradação das proteínas e ácidos nucléicos, além da lise da parede por enzimas autolíticas (McDONNELL; RUSSELL $\left.{ }^{64}, 1999\right)$ ).

Embora possuam atividade sobre as células dos microorganismos, tais compostos não são esporocidas, virucidas, tuberculocidas e tampouco destroem bactérias gram-negativas. Além disso, são inativados por sabão e resíduos orgânicos (COTTONE; MOLINARI ${ }^{27}, 1987$, MOLINARI et al. ${ }^{69}, 1988$, RUTALA $^{91}, 1996$ ).

Substâncias químicas como os compostos de amônia quaternária não são aceitos pelo Conselho em Terapêutica Dental da ADA para uso em odontologia (COUNCIL ON DENTAL MATERIALS AND DEVICES; COUNCIL ON DENTAL THERAPEUTICS $^{28}, 1988$, CRAWFORD $^{31}, 1985$ MOLINARI; RUNNELLS $^{71}, 1991$, WOOD $\left.^{114}, 1992\right)$.

\subsubsection{2. Álcool}

A exposição ao álcool provoca desnaturação de proteínas e interferências no metabolismo da célula microbiana, provocando sua ruptura. Entretanto, na presença de proteínas teciduais, como aquelas encontradas na saliva e no sangue, seu efeito desinfetante é atenuado, pois estas, quando desnaturadas, protegem os microorganismos contaminantes da lise celular. Seus efeitos sobre bactérias cobertas com proteínas e vírus comumente encontrados nas partículas geradas durante procedimentos 
odontológicos também são limitados por sua rápida evaporação (MOLINARI; RUNNELLS $^{71}$, 1991; MOLINARI et al. ${ }^{69}$, 1988).

O álcool é bactericida contra a maioria das bactérias gram-positivas e gramnegativas, tuberculicida, econômico e pouco irritante. Todavia, é ineficaz contra esporos bacterianos; tem atividade virucida irregular e diminuída na presença de matéria orgânica; faltam evidências sobre sua capacidade de inativar alguns vírus lipofílicos, como o $\mathrm{HBV}$; tem efeito deteriorante em certos materiais e evaporação rápida (COTTONE; MOLINARI $\left.{ }^{27}, 1987\right)$.

Segundo a ADA, o álcool não é recomendado para uso como desinfetante de superfície e de instrumentos, pois apresenta problemas inerentes às suas ações químicas $\left(\right.$ CRAWFORD $^{31}, 1985$, COTTONE; MOLINARI ${ }^{27}, 1987$, MOLINARI et al. $\left.{ }^{69}, 1988\right)$.

\subsubsection{Formaldeído}

O formaldeído apresenta-se na forma de gás incolor, inflamável, de odor forte e sufocante. É capaz de destruir microorganismos por meio da alteração química de suas proteínas e ácidos nucléicos (McDONNELL; RUSSELL ${ }^{64}, 1999$ ).

Por emitir vapores voláteis irritantes a pele, olhos, tecidos orais e respiratórios, tendo também potencial carcinogênico, sua utilidade em odontologia está contra indicada (COUNCIL ON DENTAL THERAPEUTICS; COUNCIL ON PROSTHETIC SERVICES AND DENTAL LABORATORY RELATIONS ${ }^{29}$, 1985).

\subsubsection{Desinfetantes químicos para uso em odontologia aceitos pela ADA}

A ADA aceita quatro categorias de desinfetantes para uso em odontologia: compostos clorados, iodóforos, fenóis sintéticos e glutaraldeídos (MERCHANT; MOLINARI $^{67}, 1989$, MOLINARI; RUNNELLS $\left.{ }^{71}, 1991\right)$.

\subsubsection{Compostos clorados}

Os compostos clorados comumente usados são preparações de dióxido de cloro e soluções de hipoclorito de sódio (MOLINARI; RUNNELLS ${ }^{71}$, 1991, MOLINARI et al. $\left.{ }^{69}, 1988\right)$. 
O cloro age primariamente no microorganismo pela oxidação, na forma de ácido hipocloroso (MOLINARI et al. ${ }^{69}$, 1988), impedindo a atividade celular das proteínas e inativando os ácidos nucléicos (RUTALA $\left.{ }^{91}, 1996\right)$.

$\mathrm{O}$ aumento da atividade biocida ocorre em $\mathrm{pH}$ baixo, onde a capacidade de oxidação é máxima (McDONNELL; RUSSELL ${ }^{64}$, 1999).

\subsubsection{1. Ácido cloroso e dióxido de cloro}

O ácido cloroso e o dióxido de cloro são produzidos pela combinação do cloreto de sódio com um ácido orgânico. Os produtos disponíveis nessa categoria produzem desinfecção de alto nível em três minutos (WOOD ${ }^{114}$, 1992) e esterilização em 6 horas de exposição; podendo ser utilizados como desinfetantes de superfície e para desinfecções por imersão (MOLINARI; RUNNELLS ${ }^{71}, 1991$ ).

A atividade biocida do dióxido de cloro foi verificada em estudo de BELL et al. ${ }^{13}$, 1989, no qual esta solução eliminou grande parte dos microorganismos em desinfecção por 2 minutos. Outro estudo também comprovou sua ação desinfetante após imersão por 3 minutos, confirmado sua eficácia como desinfetante para as superfícies externas e internas de resinas acrílicas (LIN et al. $\left.{ }^{58}, 1999\right)$.

Como desvantagens, o ácido cloroso e o dióxido de cloro causam corrosão, irritação da pele e mucosas (MOLINARI; MERCHANT; GLEASON, ${ }^{70}$ 1990), além de não poderem ser reutilizados e terem ação desinfetante prejudicada, na presença de matéria orgânica (MOLINARI; RUNNELLS ${ }^{71}$, 1991).

\subsection{Hipoclorito de sódio}

Os hipocloritos são os compostos de cloro mais antigos e mais amplamente utilizados no campo da desinfecção química, pois são germicidas poderosos, de amplo espectro antimicrobiano, não prejudiciais ao homem nas concentrações comercializadas, sem resíduos nocivos nem alteração da cor da solução, e por serem de fácil manuseio e baixo custo (BLOCK $\left.{ }^{14}, 1991\right)$.

As soluções de hipoclorito de sódio podem apresentar concentrações variando de 1 a $15 \%$, dependendo da finalidade de uso, uma vez que são utilizadas tanto para uso doméstico, quanto para uso industrial, além de serem empregadas como 
desinfetantes hospitalares, para consultório odontológico e outros locais $\left(\mathrm{BLOCK}^{14}\right.$, 1991).

Em odontologia, essas soluções foram introduzidas como anti-sépticos em 1835, podendo ser empregados na concentração de 5,25\%, que é uma combinação de cloro ativado com bases fortes; ou em concentrações menores, de 2\%, $1 \%$ ou até mesmo diluída $0,5 \%$. O tempo de imersão é variável, de acordo com a concentração utilizada, podendo oscilar entre 5 e 30 minutos, não sendo recomendado exceder mais de 30 minutos. (COUNCIL ON DENTAL THERAPEUTICS; COUNCIL ON PROSTHETIC SERVICES AND DENTAL LABORATORY RELATIONS ${ }^{29}, 1985$, WOOD ${ }^{114}, 1992$ ).

Como o hipoclorito de sódio tende a ser instável, alguns autores consideram que as soluções devem ser preparadas diariamente e descartadas após o uso (COUNCIL ON DENTAL THERAPEUTICS; COUNCIL ON PROSTHETIC SERVICES AND DENTAL LABORATORY RELATIONS ${ }^{29}$, 1985, MOLINARI; RUNNELLS ${ }^{71}, 1991$ ). Entretanto, GERHARDT; WILLIAMS ${ }^{40}$, 1991, em seu estudo sobre os efeitos do tempo, armazenamento e uso na estabilidade de soluções cloradas, preparadas para desinfecção de materiais de moldagem odontológicos, concluíram que uma mesma solução de cloro, para fins de desinfecção, se mantém efetiva num período de 1 semana.

Desinfetantes a base de hipoclorito de sódio são apropriados para desinfecção por imersão da maioria dos itens transportados para e do laboratório odontológico, contudo, podem distorcer e danificar certos materiais (MERCHANT ${ }^{66}$, 1997), provocar corrosão de metais, irritação da pele e mucosas, manchar tecidos (COUNCIL ON DENTAL THERAPEUTICS; COUNCIL ON PROSTHETIC SERVICES AND DENTAL LABORATORY RELATIONS ${ }^{29}$, 1985, MOLINARI; RUNNELLS $^{71}$, 1991, RUTALA; WEBER ${ }^{92}$, 1997), degradar instrumentos de plástico e de borracha, além de apresentarem odor forte e desagradável (COTTONE; MOLINARI $\left.^{27}, 1987\right)$.

Os efeitos esporocidas são conseguidos somente com altas concentrações de cloro e sua atividade biocida é diminuída na presença de matéria orgânica (COTTONE; MOLINARI $^{27}, 1987$, RUTALA; WEBER $\left.{ }^{92}, 1997\right)$

\subsubsection{Fenóis sintéticos}

Os fenóis sintéticos são utilizados como desinfetantes de superfície. Apresentam atividade bactericida, fungicida, viruscida, tuberculicida, mas podem 
provocar irritação da pele e dos olhos, e degradar materiais plásticos após exposição prolongada (MOLINARI et al. $\left.{ }^{69}, 1988\right)$.

São compostos constituídos por mais de um agente fenólico, que após serem diluídos em água, atuam sinergicamente para garantir um largo espectro antimicrobiano, incluindo atividade tuberculicida (MOLINARI; RUNNELLS ${ }^{71}$, 1991, MOLINARI et al. $\left.{ }^{69}, 1988\right)$.

Essas soluções agem como toxinas citoplasmáticas; penetram e rompem as paredes celulares dos microorganismos e provocam a precipitação das proteínas (RUTALA ${ }^{91}$, 1996), além da perda de seus constituintes intracelulares (McDONNELL; RUSSELL $^{64}$, 1999). Sua alta capacidade de penetração é provavelmente o grande fator associado com sua atividade antimicrobiana (MOLINARI; RUNNELLS ${ }^{71}$, 1991).

\subsubsection{Glutaraldeído}

O glutaraldeído é um poderoso agente biocida, o qual tem a vantagem de não ser inativado na presença de matéria orgânica ou degradado por sabões e detergentes. Seu uso iniciou-se em 1962, como substância substituta do formaldeído, capaz de esterilizar equipamentos que não poderiam ser esterilizados através dos métodos físicos. Mas foi a partir do final de 1963 que a formulação de glutaraldeído foi consagrada como esterilizante químico (BLOCK $\left.{ }^{14}, 1991\right)$.

Seu uso em odontologia é recente, tendo sido desenvolvido nas últimas décadas, e é universalmente reconhecido como o desinfetante/esterilizante mais eficaz (COTTONE; MOLINARI $\left.{ }^{27}, 1987\right)$.

As preparações comerciais estão disponíveis em soluções ácidas ( $\mathrm{pH}$ 4,0 a 6,5), alcalina ( $\mathrm{pH} 7,0$ a 8,5) ou neutras ( $\mathrm{pH} \mathrm{7,0} \mathrm{a} \mathrm{7,5),} \mathrm{sendo} \mathrm{que} \mathrm{os} \mathrm{dois} \mathrm{últimos}$ necessitam de um ativador que estabiliza a solução final no $\mathrm{pH}$ desejado (WOOD ${ }^{114}$, 1992).

Em concentrações de $2,0 \%$ e $3,2 \%$ pode ser eficaz contra bactérias vegetativas, incluindo Mycobacterium tuberculosis, fungos e vírus. Nestas mesmas concentrações, em um período de imersão de 10 horas, tem atividade esporocida (MOLINARI; RUNNELLS ${ }^{71}, 1991$, MOLINARI et al. ${ }^{69}, 1988$ ).

Apresenta largo espectro antibacteriano em 20-30 minutos, duração prolongada e não degrada artigos de borracha e plástico (COTTONE; MOLINARI, ${ }^{27}$ 1987). 
Seu mecanismo de ação envolve uma forte associação com as camadas externas das células bacterianas (McDONNELL; RUSSELL ${ }^{64}$, 1999), alterando seus ácidos nucléicos (RUTALA ${ }^{91}$, 1996) e evitando a passagem de nutrientes para o interior da célula (CIANCIO $\left.{ }^{26}, 1986\right)$.

Como desvantagem, causa irritações na pele e mucosas, podendo inclusive manchar e desencadear alergias cutâneas quando a exposição é repetida; também provoca injúrias oculares e danifica objetos metálicos se usado incorretamente (CIANCIO $^{26}$, 1986, MERCHANT; MOLINARI ${ }^{67}, 1989$, MOLINARI; MERCHANT; GLEASON $^{70}, 1990$, MOLINARI; RUNNELLS ${ }^{71}, 1991$, MOLINARI et al. ${ }^{69}, 1988$ ).

\subsubsection{Iodóforos}

Tradicionalmente, o iodo tem sido usado como anti-séptico para aplicação sobre a pele, membranas mucosas e ferimentos. Sua ação antimicrobiana é bastante rápida, mesmo em baixas concentrações; altera ácidos nucléicos $\left(\operatorname{RUTALA}^{91}, 1996\right)$ e evita a passagem de nutrientes para o interior das células $\left(\right.$ CIANCIO $\left.^{26}, 1986\right)$.

A partir das tentativas de usar o efeito germicida potente do iodo e reduzir o efeito caústico e de manchamento, sintetizaram outro composto, chamado de iodóforo. Os iodóforos são preparados pela combinação do iodo com um agente solubilizante e carregador. Um dos carreadores mais comuns é a polivinilpirrolidona (PVP), que minimiza sua toxicidade e o libera lentamente (MOLINARI; RUNNELLS ${ }^{71}$, 1991, MOLINARI et al. ${ }^{69}$, 1988). São usados como desinfetantes de imersão ou de superfície e são eficazes contra uma grande variedade de microorganismos, incluindo Mycobacterium tuberculosis, mas não são aprovados como esterilizantes.

Apresentam largo espectro antimicrobiano; são mais eficientes em soluções diluídas que em concentradas; econômicos; produzem poucas reações físicas colaterais; a desinfecção da superfície ocorre entre 3 a 30 minutos, dependendo da quantidade de resíduos presentes; têm atividade prolongada após aplicação e o carreador surfactante ajuda manter a superfície úmida e protege o iodóforo durante sua ação (COTTONE; MOLINARI $^{27}$, 1987). São anti-sépticos eficazes para as mãos, não mancham a pele, menos irritantes aos tecidos e menos alergênicos que as tinturas de iodo.

Em contrapartida, são instáveis, perdem sua atividade com o tempo, não são classificados como esterilizantes, corrosivos para alguns metais, podem descolorir 
algumas superfícies com o uso repetido e são inativados por álcool (COTTONE; MOLINARI $\left.^{27}, 1987\right)$.

\subsection{Desinfecção de próteses totais}

Em vista do acúmulo de biofilme microbiano na superfície do acrílico das próteses totais (VERRAN; MARYAN ${ }^{107}$, 1997) e considerando que os microorganismos os quais o compõe são causadores de patologias locais e sistêmicas (NIKAWA; HAMADA; YAMAMOTO ${ }^{76}, 1998$, PIRES et al ${ }^{84}, 2002$ ), é de extrema importância a realização de procedimentos de desinfecção para assegurar a saúde do paciente.

O uso de soluções químicas é uma alternativa eficaz para desinfecção, porém, existem muitas controvérsias quanto ao tipo de desinfetante, ao período de desinfecção das próteses e à concentração da solução (MA; JOHNSON; GORDON ${ }^{62}$, 1997, SAUNDERS et al. ${ }^{95}$, 1998, WEBB et al. ${ }^{110}$, 1998, FURUKAWA et al. ${ }^{39}, 1998$, LIN et al. ${ }^{58}, 1999$, PAVARINA et al. $\left.{ }^{81}, 2003\right)$. Apesar da incongruência de resultados de alguns trabalhos, o objetivo sempre será o de oferecer ao paciente a possibilidade de desinfetar as próteses totais em um menor tempo possível.

Embora alguns trabalhos tenham testado desinfetantes como o dióxido de cloro (BELL et al. ${ }^{13}$, 1989, BRACE; PLUMMER ${ }^{16}$, 1993, CHAU et al. ${ }^{25}$, 1995, FURUKAWA et al. ${ }^{39}$, 1998, LIN et al. $\left.{ }^{58}, 1999\right)$ e iodóforos (CHAU et al. ${ }^{25}$, 1995, MA; JOHNSON; GORDON ${ }^{62}$, 1997, PAVARINA et al. ${ }^{81}$, 2003), a maioria dos estudos encontrados na literatura testou as soluções desinfetantes de hipoclorito de sódio (GHALICHEBAF; GRASER; ZANDER ${ }^{41}$, 1982, RUDD et al. ${ }^{90}, 1984$, COTTONE; MOLINARI $^{27}$, 1987, HENDERSON et al. ${ }^{46}$, 1987, MC GOWAN; SHIMODA; WOOLSEY ${ }^{65}$, 1988, BELL et al. ${ }^{13}$, 1989, CHAU et al. ${ }^{25}$, 1995, MA; JOHNSON; GORDON $^{62}$, 1997, SAUNDERS et al. ${ }^{95}$, 1988, WEBB et al. ${ }^{110}$, 1998, PAVARINA et al. ${ }^{81}, 2003$, NEPPELENBROEK et al. ${ }^{74}, 2005$, YILMAZ et al. ${ }^{116}, 2005$, AZEVEDO et al. $^{10}$, 2006), glutaraldeído (POLYZOIS; ZISSIS; YANNIKAKIS ${ }^{85}, 1995$, HENDERSON et al. $^{46}$, 1987, ASAD; WATKINSON; HUGGET ${ }^{8}$, 1992, MA; JOHNSON; GORDON ${ }^{62}$, 1997) e gluconato de clorexidina (ASAD; WATKINSON; HUGGET $^{8}$, 1992, PAVARINA et al. ${ }^{81}$, 2003, PAVARINA et al. ${ }^{82}$, 2003, NEPPELENBROEK et al. ${ }^{74}, 2005$, AZEVEDO et al. $\left.{ }^{10}, 2006\right)$. 
Alguns trabalhos, os quais apresentaram culturas negativas, recomendam a imersão de próteses totais em hipoclorito de sódio a 5,25\% diluído a 1:10 por 10 minutos (SAUNDERS et al. ${ }^{95}$, 1998), enquanto outros aconselham a mesma concentração diluída 1:5 a 1:100 em intervalos de 10 a 30 minutos (COTTONE; MOLINARI $\left.^{27}, 1987\right)$.

O tempo de imersão em hipoclorito de sódio na concentração de 5,25\%, não diluído, capaz de promover a desinfecção de uma prótese total foi descrito por RUDD et al. ${ }^{90}$, em 1984. Para os autores, o tempo ideal de imersão seria de 5 minutos. No entanto, outros estudos, comparando diferentes soluções, utilizaram tempos diferentes para a desinfecção com hipoclorito de sódio a 5,25\% (BELL et al. ${ }^{13}$, 1989, CHAU et al. ${ }^{25}$, 1995, SAUNDERS et al. ${ }^{95}$, 1998).

A concentração de 5,25\% não diluída de hipoclorito de sódio atingiu níveis significativamente melhores de desinfecção, em imersão de 4 minutos, quando comparado a imersões em dióxido de cloro durante 2 e 3 minutos (BELL et al. ${ }^{13}, 1989$ ). CHAU et al. ${ }^{25}$, em 1995, também compararam as duas soluções, mas com tempo de imersão de 10 minutos, e constataram que somente o hipoclorito de sódio foi capaz de desinfetar a porção interna das resinas acrílicas.

Esta concentração de hipoclorito de sódio também se revelou mais eficaz no estudo de SAUNDERS et al. ${ }^{95}, 1998$, quando comparada aos compostos iodóforos, em um experimento onde amostras de resina acrílica eram desinfetadas, durante 10 minutos, por essas substâncias.

Preocupado com a possibilidade de desinfetar materiais diferentes em uma prótese (resina e metal), MC GOWAN; SHIMODA; WOOLSEY ${ }^{65}, 1988$, avaliaram o efeito desinfetante do hipoclorito de sódio nas concentrações de 2\%, 3\%, 4\% e 5,25\%, durante 3,5 e 30 minutos para desinfecção de próteses parciais removíveis sem causar danos à estrutura metálica. As imersões por 5 minutos em hipoclorito de sódio a $2 \%$ e a $5,25 \%$ por 3 minutos foram efetivas para desinfecção das bases de resina sem causar corrosão ao metal da prótese.

Comparação entre as soluções de hipoclorito de sódio a $5,25 \%$ e a $2 \%$ foi realizada também em um estudo de YILMAZ et al. ${ }^{116}$, 2005. Concluiu-se que em 5 minutos de imersão, a solução de concentração 5,25\% foi mais efetiva que a de $2 \%$, no entanto, ambas reduziram significativamente o número de microorganismos testados. A concentração de $1 \%$, testada por PAVARINA et al. ${ }^{81}$, 2003, também apresentou culturas negativas em imersões de 10 minutos, quando eram mantidas em agitação ou não. 
Ainda em estudos comparativos avaliando a eficácia de soluções desinfetantes sobre próteses totais, HENDERSON et al. ${ }^{46}$, 1987 utilizaram, além do hipoclorito de sódio a $5,25 \%$, a solução de glutaraldeído em duas concentrações $(2 \%$ concentrado e $2 \%$ diluído 1:16), com imersão de 10 minutos. Verificou-se redução significativa de bactérias na superfície de próteses totais para ambas as soluções testadas.

Além das soluções de hipoclorito de sódio e glutaraldeído, o gluconato de clorexidina também foi utilizado para desinfecção de próteses totais, através de imersão. A concentração de $4 \%$, em imersões de 10 minutos, garantiu eficácia na desinfecção, independente da agitação em ultra-som. (PAVARINA et al. ${ }^{81}$, 2003).

\subsection{Efeitos adversos das soluções desinfetantes sobre as bases de prótese total}

Diante de inúmeras evidências na literatura salientando a importância do uso de soluções químicas para desinfecção de bases de próteses totais e controle de infecção cruzada, esta prática tem se tornado rotineira, porém, tão importante quanto saber qual o tipo de solução utilizar é conhecer se a solução química, a concentração e o tempo de imersão escolhidos são compatíveis com a base que compõe uma prótese total, para evitar efeitos adversos nas resinas acrílicas.

Grande parte dos estudos encontrados na literatura apresenta apenas avaliações em curto prazo sobre os efeitos das soluções desinfetantes sobre as resinas acrílicas (SHEN; JAVID; COLAIZZI ${ }^{97}$, 1989, ASAD; WATKINSON; HUGGET ${ }^{8}$, 1992, MA; JOHNSON; GORDON ${ }^{62}$, 1997, POLYZOIS; ZISSIS; YANNIKAKIS ${ }^{85}$, 1995, ZISSIS et al. ${ }^{118}, 2000$, PAVARINA et al. ${ }^{80}, 2003$, NEPPELENBROEK et al. ${ }^{74}$, 2005, AZEVEDO et al. ${ }^{10}$, 2006).

De acordo com ZISSIS et al. ${ }^{118}$, 2000, dentre as propriedades requeridas dos materiais usados na confecção de dentaduras, aquelas relacionadas com a superfície, rugosidade, tensão superficial, interações eletrostáticas e microdureza são de importância clínica, desde que possam causar acúmulo de biofilme e manchamento. Em particular, a rugosidade de superfície provoca adesão e retenção de Candida albicans, a qual é de importância específica na indução de estomatites.

$\mathrm{O}$ efeito de soluções químicas desinfetantes na rugosidade superficial e na cor de resinas para base de dentaduras foi avaliado por MA; JOHNSON; GORDON ${ }^{62}$, 
1997. Concluiu-se que apenas um desinfetante à base de fenol (Multicide) não pode ser usado para as cinco resinas testadas; e que todas as resinas podem ser imersas nas demais soluções desinfetantes utilizadas num período de até 30 minutos sem apresentar alterações de rugosidade superficial e cor.

POLYZOIS; ZISSIS; YANNIKAKIS ${ }^{85}$, 1995, avaliaram o efeito de métodos de desinfecção na estabilidade dimensional, propriedades flexurais e microdureza de resinas acrílicas termopolimerizáveis, utilizando imersão em glutaraldeído alcalino $2 \%$ por 1 e 2 horas e exposição à energia de microondas (500W) por 3 e 15 minutos. Todos os espécimes sofreram alterações lineares após os tratamentos de desinfecção, mas não eram clinicamente significantes.

O efeito da desinfecção por glutaraldeído durante 12 horas nas propriedades flexurais e microdureza de resinas acrílicas foi estudado por SHEN; JAVID; $\operatorname{COLAIZZI}^{97}$, 1989, que afirmaram não haver alterações dessas propriedades. Resultado semelhante foi obtido por ASAD; WATKINSON; HUGGET ${ }^{8}, 1992$.

PAVARINA et al. ${ }^{82}, 2003$, estudaram o efeito de soluções desinfetantes na microdureza de dentes de resina acrílica, utilizando três soluções (gluconato de clorexidina a $4 \%$, hipoclorito de sódio a $1 \%$ e perborato de sódio a 3,78\%) com tempo de imersão de 10 minutos. Não houve diferenças significantes na microdureza após imersão nas soluções. Os mesmos autores avaliaram os efeitos destas substâncias na resistência flexural de duas resinas acrílicas termopolimerizáveis, utilizadas para confecção de bases de próteses totais, após duas imersões de 10 minutos cada. Os resultados demonstraram que a resistência flexural de ambas as resinas não foram afetadas pelos diferentes tratamentos desinfetantes (PAVARINA et al. ${ }^{80}, 2003$ ).

A dureza de duas resinas acrílicas termopolimerizavéis foi avaliada por NEPPELENBROEK et al. ${ }^{74}, 2005$, após 4 procedimentos de desinfecção, simulando as desinfecções que devem ocorrer entre os procedimentos clínicos e laboratoriais, em soluções de gluconato de clorexidina a $4 \%$, hipoclorito de sódio a $1 \%$ e perborato de sódio a 3,78\%, em imersões de 10 minutos e após serem armazenadas em água durante 15, 30, 60, 90 e 120 dias. Observou-se uma diminuição dos valores de dureza, após a desinfecção, de ambos os materiais testados, independente da solução desinfetante utilizada. No entanto, após o armazenamento em água, os valores aumentaram, até a análise de 60 dias. Os períodos seguintes não apresentaram aumento nos valores de dureza. 
AZEVEDO et al. ${ }^{10}, 2006$, analisou as alterações de rugosidade e dureza de três resinas acrílicas termopolimerizáveis após desinfecção com soluções de hipoclorito de sódio $1 \%$ e gluconato de clorexidina $4 \%$ e perborato de sódio a $3,78 \%$. Os testes foram realizados 1 hora após a polimerização, após $48 \mathrm{~h}$ de armazenamento em água destilada, após 2 ciclos de desinfecção, sendo cada um de 10 minutos, e finalmente, após 7 dias de imersão nos desinfetantes. Apenas um dos materiais testados apresentou alteração discreta, embora significante, nos valores de dureza, após imersão nas soluções durante 7 dias. Não houve alterações nos valores de rugosidade dos materiais testados após 7 dias de imersão nas soluções desinfetantes testadas.

Embora conste na literatura estudos com períodos curtos de avaliação, envolvendo o efeito de soluções químicas desinfetantes sobre as resinas acrílicas, nenhuma informação foi encontrada a cerca do efeito dessas soluções em longo prazo. 
2. Proposição 



\section{Proposição}

A partir da revisão da literatura e questionamentos referentes ao tema, este trabalho se propôs à:

1) Avaliar, longitudinalmente, as alterações de microdureza e rugosidade superficial de resinas acrílicas para base de dentaduras e resinas rígidas para reembasamento, em duas situações distintas: armazenamento em água, durante o período noturno; e higienização com soluções desinfetantes.

1.1.Verificar o efeito da água e dos desinfetantes sobre as alterações de microdureza e rugosidade superficial das resinas acrílicas estudadas, ao longo dos intervalos de avaliação.

1.2.Analisar o comportamento de cada solução utilizada sobre as alterações de microdureza e rugosidade superficial das resinas acrílicas estudadas, em cada intervalo de avaliação.

2) Determinar, ao final do experimento, qual a solução desinfetante que causou maiores danos a cada uma das resinas acrílicas estudadas. 

3. Material

e Métodos 



\section{Material e Métodos}

Este experimento foi realizado em duas etapas. A primeira etapa compreende a confecção e polimento dos 240 corpos de prova utilizados na pesquisa, bem como sua distribuição randomizada entre os grupos estudados. Na segunda etapa, os corpos de prova de cada grupo avaliado foram, inicialmente, submetidos aos testes de microdureza e rugosidade superficial e em seguida, 5 grupos foram desinfetados, de acordo com o protocolo de desinfecção, utilizando soluções químicas, e 1 grupo foi armazenado em água. Os testes de microdureza e rugosidade superficial foram repetidos após a simulação de armazenamento em água e desinfecções diárias durante 1 mês, 3 e 6 meses, que correspondem ao intervalo de 1-30, 31-90 e 91-180 ciclos de imersão.

\subsection{Confecção dos corpos de prova}

\subsubsection{Confecção dos corpos de prova da resina termopolimerizável}

\subsubsection{Confecção dos padrões de silicone para inclusão}

Para a confecção dos corpos de prova utilizados neste experimento, inicialmente foram obtidos padrões de silicone por condensação de uso laboratorial Zetalabor (Hard 85 shore-A, Zhermack, Italy). Esses padrões foram confeccionados a partir de uma matriz plástica, de forma circular, medindo $30 \mathrm{~mm}$ de diâmetro e $6 \mathrm{~mm}$ de altura. No interior da matriz foram confeccionadas 4 endentações positivas, envolvendo toda a porção lateral da matriz, de forma equiidistante, as quais foram transferidas de forma negativa ao silicone, dividindo a circunferência em 4 quadrantes iguais, que auxiliaram na divisão do corpo de prova para a leitura dos testes (FIGURA 1). 


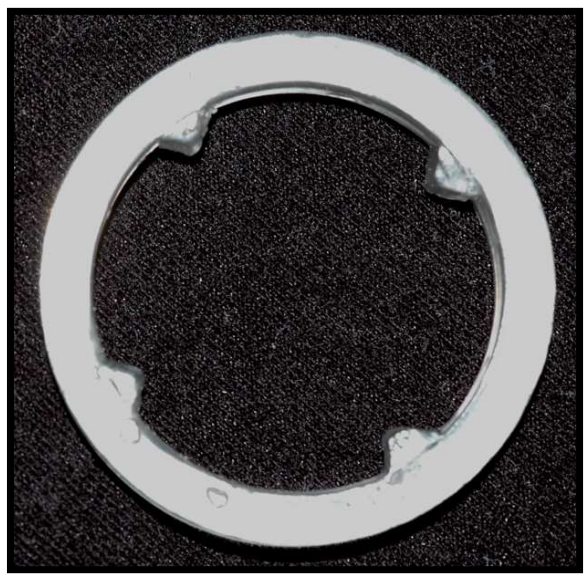

FIGURA 1 - Matriz plástica para confecção dos padrões em silicone

A matriz foi preenchida por silicone por condensação de uso laboratorial Zetalabor e prensada entre duas placas de vidro (JON Com de produtos odontológicos LTDA, São Paulo, SP) previamente isoladas com vaselina sólida (Hemafarma Com. E Ind farmacêutica LTDA, São Gonçalo, RJ), sob peso de 5kg, por aproximadamente 10 minutos (FIGURA 2). Em seguida, o padrão de silicone foi removido da matriz e os excessos foram cortados com auxílio de uma lâmina de estilete (FIGURA 3).

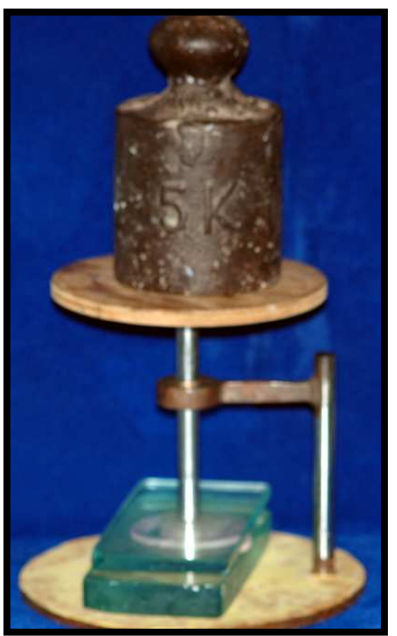

FIGURA 2- Prensagem do padrão de silicone

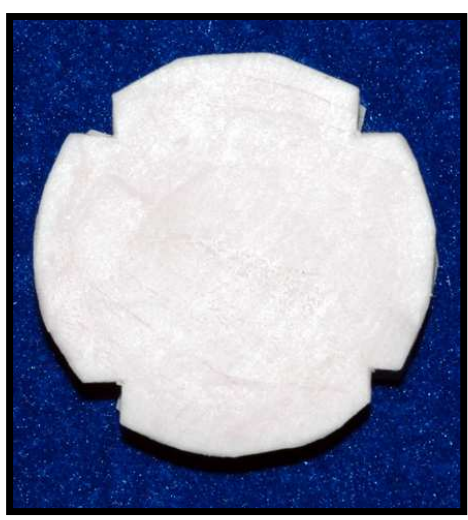

FIGURA 3- Padrão de silicone pronto para ser incluído em mufla 


\subsubsection{Inclusão}

Os padrões de silicone foram retirados da matriz plástica e incluídos em muflas de latão polido com pino n ${ }^{\circ} 6$ (Mac Artigos odontológicos e prótese Ind. e Com. LTDA, São Paulo, SP), anteriormente isoladas com vaselina sólida. Posteriormente, as muflas metálicas foram preenchidas com gesso pedra tipo III (Gesso Pedra Herodent Vigodent S/A Ind. e Com., Rio de Janeiro, RJ), manipulado e espatulado conforme orientações do fabricante, em cuba de borracha (Dentalbrand Comercial, São Paulo, SP) com espátula para gesso (Indusbello Ind. de Instr. Odontológicos, Londrina, PR), sob vibração.

Após a presa, os padrões de silicone foram colocados sobre o gesso e uma nova camada deste foi colocada entre eles, a fim de fixá-los na mufla. Esperou-se o tempo de presa da segunda camada e em seguida, foi aplicada vaselina sólida em toda superfície. A contra mufla também recebeu uma camada de vaselina sólida nas suas superfícies internas e posteriormente, foi posicionada e devidamente preenchida com gesso pedra tipo III, conforme condições técnicas descritas anteriormente.

As muflas permaneceram na prensa hidráulica (VH Equipamentos médicos Odont. Acess. LTDA., Araraquara, SP) com 0,5 Kgf de pressão, por uma hora, e em seguida, foram abertas para a remoção das matrizes de silicone e realização do exame do molde no gesso, a fim de verificar a presença de bolhas.

\subsubsection{Termopolimerização}

Para prensagem, foi utilizada a resina acrílica termopolimerizável de cor rosa Lucitone 550 (Dentsply International INC., Chicago, IL, USA), homogeneizada com auxílio de uma espátula $\mathrm{n}^{\circ} 31$ (SS White Art. Dentários LTDA, Rio de Janeiro, RJ) em recipiente de vidro (Paladon, Pr. Ind. e Comércio de produtos odontológicos, Florianópolis, SC), utilizando-se a proporção de $21 \mathrm{~g}$ de pó para $10 \mathrm{ml}$ de líquido, conforme orientações do fabricante. $\mathrm{O}$ interior dos moldes de gesso foi isolado com isolante para resina acrílica (Cel-Lac, S.S. White Artigos Dentários, Rio de Janeiro, RJ), com auxílio de um pincel de pêlo de marta (Condor, $n^{\circ} 456$, Condor S.A., São Bento do Sul, SC) e preenchido com a resina acrílica na fase plástica. A base da mufla foi coberta com uma folha de papel celofane e fechada com a sua respectiva porção superior para 
ser prensada em prensa hidráulica sob pressão inicial de $0,5 \mathrm{kgf}$. No momento em que o ponteiro da prensa hidráulica apresentou-se estável, a pressão foi aumentada para $1 \mathrm{kgf}$ e por fim, até atingir 1,5 kgf. Após a estabilização do ponteiro em 1,5 kgf e escoamento completo do excesso da resina acrílica, a mufla foi novamente aberta, o papel celofane removido, e a película de resina acrílica excedente eliminada com o auxílio de uma espátula Lecron (S.S. White Art. Dentários LTDA, Rio de Janeiro, RJ). A mufla foi novamente fechada e levada para prensa hidráulica sob pressão de 1,5 kgf durante 30 minutos.

Decorrido esse período, a mufla foi colocada em uma prensa de aço inoxidável (Metal Vander Aparelhos para Ortodontia, Piracicaba, SP), passível de ser utilizada em polimerizadoras digitais, e levada, em água, à polimerizadora microprocessada digital, modelo Banho Maria (Solab, Piracicaba, SP), para que se procedesse a termopolimerização com a seguinte programação: a temperatura da água elevou-se até $73^{\circ} \mathrm{C}$ e manteve-se estável durante 90 minutos, em seguida, tornou a subir até atingir $100^{\circ} \mathrm{C}$, que foram mantidos por mais 30 minutos (FIGURA 4).

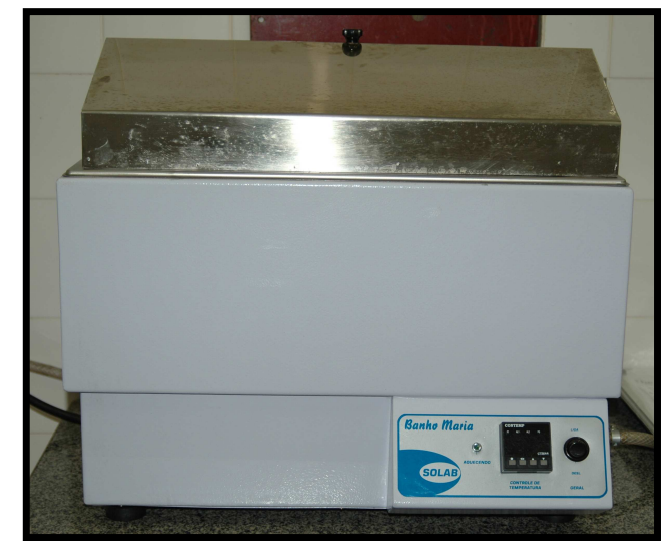

FIGURA 4 - polimerizadora microprocessada digital

\subsubsection{Demuflagem}

Após o período de polimerização das amostras, as muflas foram removidas da polimerizadora microprocessada digital e deixadas sobre a bancada para resfriar, por um período de aproximadamente 5 horas. Dado o resfriamento completo, procedeu-se a demuflagem dos espécimes (FIGURA 5). Posteriormente a demuflagem, os excessos (rebarbas) de resina acrílica foram desgastados com o auxílio de uma broca de 
tungstênio Maxicut n ${ }^{\circ} 79$ (Edenta AG, Switzerland) (FIGURA 6), e com lixa de silicone carbide de granulação 180 (Extec Corp., Enfield, USA), com refrigeração à água em politriz metalográfica manual (APL 4, Arotec, Cotia, SP), buscando-se deixar as superfícies superior e inferior dos espécimes paralelas entre si (FIGURA 7)

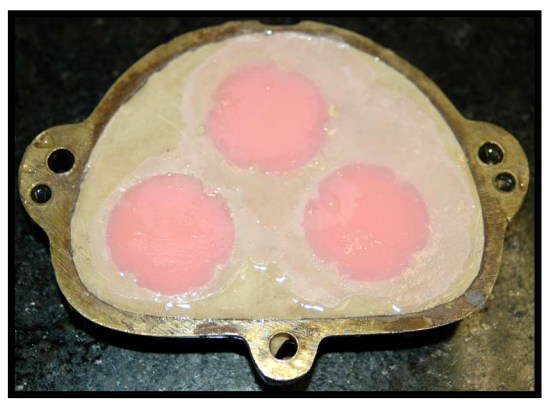

FIGURA 5- Demuflagem dos corpos de prova em resina

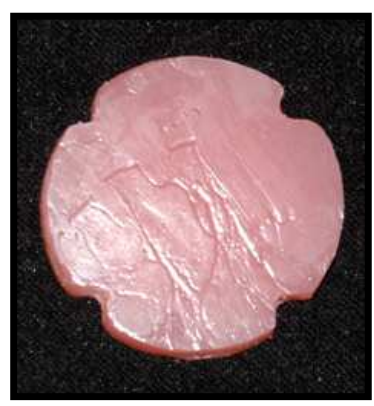

FIGURA 6- Corpo de prova após remoção das rebarbas dos excessos de resina acrílica

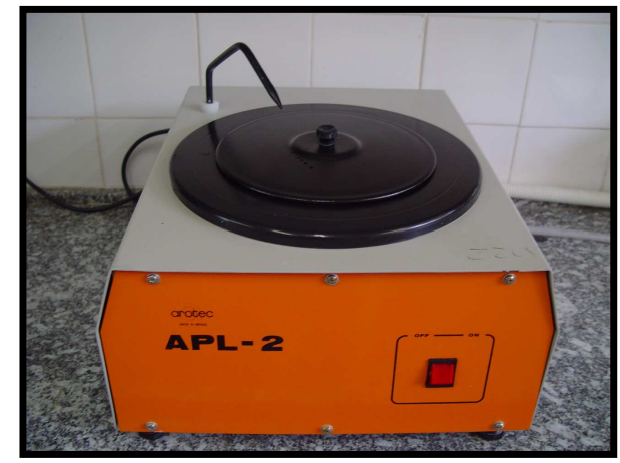

FIGURA 7 - Politriz Metalográfica Manual

\subsubsection{Confecção dos corpos de prova de resina autopolimerizável}

\subsubsection{Confecção do molde em silicone laboratorial Zetalabor para inclusão}

Para a confecção dos corpos de prova em resina autopolimerizável foi necessário criar um molde em silicone o qual permitisse que a resina fosse devidamente prensada. Para tanto, foi preciso utilizar uma mufla $n^{\circ} 6$, previamente isolada com vaselina sólida e preenchida até a metade com gesso tipo pedra tipo III, manipulado e 
espatulado conforme orientações do fabricante, em cuba de borracha, com espátula para gesso, sob vibração.

Após a presa do gesso, três corpos de prova de resina acrílica termopolimerizável foram colocados sobre o mesmo; ao redor deles, foi construída uma base de silicone laboratorial (Zetalabor). Toda superfície foi isolada com Cel-Lac, utilizando um pincel de pêlo de marta, e em seguida, foi colocada a contra-mufla, também previamente isolada com vaselina sólida e preenchida com gesso pedra tipo III. Na seqüência, a mufla foi levada à prensa hidráulica sob $0,5 \mathrm{kgf}$ de pressão, durante 1 hora, para que ocorresse a presa do gesso.

Decorrido este período, a mufla foi retirada da prensa e aberta, para que fosse possível remover os corpos de prova de resina acrílica termopolimerizável e, assim, obter um molde para a confecção dos corpos de prova de resina acrílica autopolimerizável.

\subsubsection{Confecção dos corpos de prova das resinas autopolimerizáveis para reembasamento}

Todos os corpos de prova das resinas autopolimerizáveis para reembasamento foram confeccionados a partir do molde em silicone (Zetalabor) explicado anteriormente. Para tanto, inicialmente, as superfícies do gesso da mufla e do molde de silicone, bem como a superfície do gesso da contra-mufla, foram isoladas com isolante para resinas acrílicas Cel-Lac com auxílio de pincel de pêlo de marta.

Cada resina para reembasamento, utilizada no presente estudo, foi proporcionada e manipulada de acordo com as recomendações dos fabricantes.

A resina autopolimerizável JET (Artigos Odontológicos Clássico Ltda, São Paulo, SP) foi homogeneizada com auxílio de uma espátula $\mathrm{n}^{\circ} 31$ em recipiente de vidro, utilizando-se a proporção de uma porção de pó para uma de líquido, mensuradas por um pote dosador fornecido pelo fabricante.

A resina para reembasamento Tokuyama Rebase II fast (Tokuyama Dental Corporation, Tokyo, Japan) foi proporcionada seguindo as instruções do fabricante: uma parte do frasco dosador de pó para duas partes do conta-gotas dosador de líquido, sendo ambos dosadores fornecidos pelo fabricante. Para o preenchimento completo do molde de silicone, foi necessário proporcionar o material da seguinte forma: seis partes do frasco dosador de pó para 12 partes do conta-gotas dosador de líquido. O material foi 
homogeneizado vagarosamente, incorporando o pó ao líquido, numa cuba plástica, com auxílio de uma espátula plástica, ambas fornecidas junto ao kit do material.

Para a confecção dos corpos de prova da resina para reembasamento Kooliner (GC América Inc. ALSIP, IL, USA) seguiu-se a proporção do material de acordo com as instruções estabelecidas pelo fabricante: $15 \mathrm{ml}$ de pó para $6 \mathrm{ml}$ de líquido. Esta proporção foi seguida para completar todo o molde em silicone, sendo que para tanto se utilizou $30 \mathrm{ml}$ de pó para $12 \mathrm{ml}$ de líquido. O material foi proporcionado com o uso de potes dosadores para pó e líquido fornecidos pelo fabricante. A homogeneização do produto foi realizada em recipiente de vidro, com auxílio de uma espátula $n^{\circ} 31$.

As resinas para reembasamento foram inseridas no molde de silicone em sua fase plástica e, posteriormente, a mufla foi fechada e levada à prensa hidráulica sob 0,5 kgf, durante 10 minutos, até a polimerização completa. Em seguida, a mufla foi aberta e os corpos de prova foram retirados do molde de silicone. Removeram-se os excessos de resina com fresas de tungstênio e com lixa de silicone carbide de granulação 180, com refrigeração à água, em politriz metalográfica manual, para que as superfícies dos corpos de prova ficassem paralelas entre si.

\subsection{Planificação e polimento dos corpos de prova}

Os corpos de prova foram polidos com auxílio de uma politriz metalográfica mecânica (APL 4, Arotec, Cotia, SP) com dispositivo para polimentos múltiplos, capaz de realizar um polimento simultâneo em seis corpos de prova com refrigeração de água deionizada, proporcionando o paralelismo entre as superfícies polidas. O tamanho do corpo de prova ( $6 \mathrm{~mm}$ de altura e $30 \mathrm{~mm}$ de diâmetro) permitiu a completa adaptação dos mesmos aos orifícios onde se encaixam os elementos a serem polidos na politriz metalográfica (FIGURA 8). 


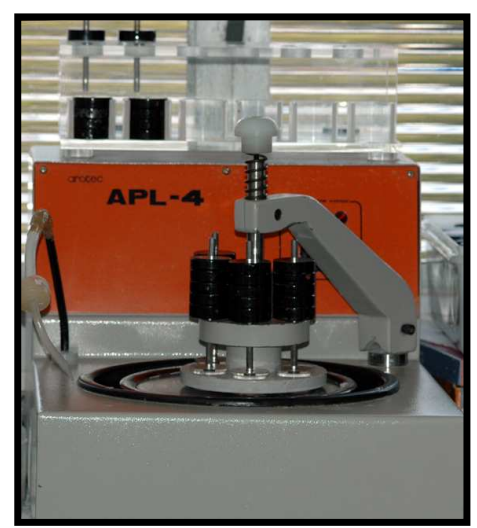

FIGURA 8 - Politriz metalográfica mecânica

A planificação das faces se iniciou com lixa de silicone carbide de granulação 320, acionando-se a politriz em alta velocidade, com carga máxima de $215 \mathrm{~g}$, durante 4 minutos. Seguiu-se o polimento com as lixas de granulação 600 e 1200, também com a carga máxima de $215 \mathrm{~g}$, durante 4 minutos, sempre com a politriz em alta velocidade.

Para o polimento final, utilizou-se um feltro (Extec Corp., Enfield, USA)

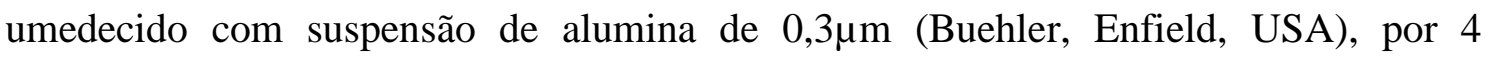
minutos em alta velocidade, com carga de $215 \mathrm{~g}$, sem refrigeração (FIGURA 9).

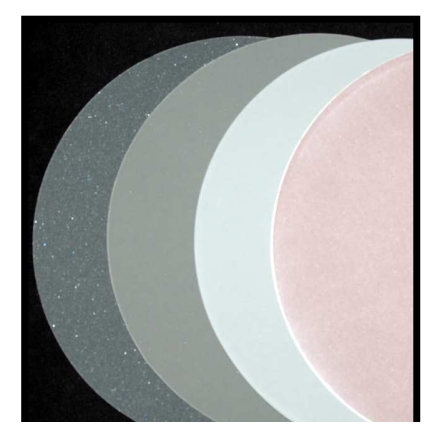

FIGURA 9 - Conjunto de lixas e feltro para polimento

Com o objetivo de impedir que os grãos das primeiras lixas interferissem na qualidade do polimento das seguintes, a cada troca de granulometria, os corpos de prova eram levados em uma lavadora ultra-sônica T7 Thornton (Unique Ind. e Com. de Produtos Eletrônicos LTDA, São Paulo, SP), com freqüência de $40 \mathrm{~Hz}$, durante 2 minutos, com água deionizada e posteriormente eram secos com papel toalha. 


\subsection{Distribuição dos grupos}

Para a realização do experimento, foram confeccionados 240 corpos de prova, sendo 60 de cada resina acrílica estudada (Lucitone 550, Jet, Kooliner e Tokuyama Rebase II fast ).

Após a confecção e polimento dos espécimes, os mesmos foram agrupados de acordo com o material utilizado para a sua confecção. Em seguida, realizou-se a distribuição randomizada dos 60 corpos de prova, em seis grupos de 10 unidades, a fim de serem submetidos a cada uma das soluções empregadas neste estudo.

SOLUÇÃO ÁGUA (CONTROLE): armazenamento em água deionizada, pelo período correspondente a 8 horas por dia, a fim de simular o tempo em que a prótese permanece imersa em água, fora da boca.

SOLUÇÃO HIPOCLORITO DE SÓDIO 1\% - NaOCl - (H1\%): desinfecção com solução de hipoclorito de sódio com concentração igual a $1 \%$ (Pharmácia Specífica Manipulação de Fórmulas, Bauru, SP), durante 10 minutos.

SOLUÇÃO HIPOCLORITO DE SÓDIO 2\% - NaOCl - (H2\%): desinfecção com solução de hipoclorito de sódio com concentração igual a $2 \%$ (Pharmácia Specífica Manipulação de Fórmulas, Bauru, SP), durante 5 minutos.

SOLUÇÃO HIPOCLORITO DE SÓDIO 5,25\% - NaOCl - (H5,25\%): desinfecção com solução de hipoclorito de sódio com concentração igual a 5,25\% (Pharmácia Specífica Manipulação de Fórmulas, Bauru, SP), durante 5 minutos.

SOLUÇÃO GLUTARALDEÍDO $2 \%$ - $\mathbf{C}_{5} \mathbf{H}_{8} \mathbf{O}_{2}$ - (G2\%): desinfecção com solução de glutaraldeído com concentração igual a 2\% (Pharmácia Specífica Manipulação de Fórmulas, Bauru, SP), durante 10 minutos.

\section{SOLUÇÃO GLUCONATO DE CLOREXIDINA 4\% -} $\mathbf{C}_{22} \mathrm{H}_{30} \mathrm{Cl}_{2} \mathbf{N}_{10}\left(\mathbf{C}_{6} \mathrm{H}_{12} \mathrm{O}_{7}\right)_{2}$ - $(\mathbf{G C 4 \%})$ : desinfecção com solução de gluconato de clorexidina com concentração igual a 4\% (Pharmácia Specífica Manipulação de Fórmulas, Bauru, SP), durante 10 minutos.

Cada grupo foi armazenado em recipientes plásticos tampados (Plasútil Ind. Com. de Plásticos LTDA, Bauru, SP) e devidamente etiquetado para identificação dos espécimes. 


\subsection{Identificação dos corpos de prova dentro de cada grupo}

Com a intenção de efetuar comparações entre os diferentes intervalos de avaliação, os corpos de prova de cada grupo foram numerados. Para tanto, utilizou-se uma fresa diamantada esférica, de número 1014 (KG Sorensen Ind. e Com. LTDA, São Paulo, SP) em alta rotação buscando numerar as laterais dos corpos de prova de 1 até 10, para cada grupo de resina estudada.

\subsection{Testes iniciais}

Previamente à realização dos testes iniciais de microdureza, os corpos de prova foram armazenados em recipientes plásticos tampados, no interior de uma estufa de cultura microbiológica, por um período de $48 \mathrm{~h}$ em água deionizada a $37^{\circ} \mathrm{C}$, conforme as normas da ADA (American Dental Association, 1975) e ISO (International Organization for Standartization Specification 1567, 1988) para o teste supracitado.

\subsubsection{Análise da microdureza dos corpos de prova}

Após o período de armazenamento em água, as mensurações de microdureza iniciais foram obtidas com o microdurômetro (HMV-2000/ Shimadzu Corporation, Japan) acoplado a um microcomputador, e um software específico para a análise das imagens (Cams-Win-New Age Industries / USA). O microdurômetro acionou uma ponta penetradora de diamante com forma piramidal com base losangular sob carga vertical estática de $25 \mathrm{~g}$ aplicada por 10 segundos, e a leitura foi realizada com a objetiva de 10 X (FIGURA 10).

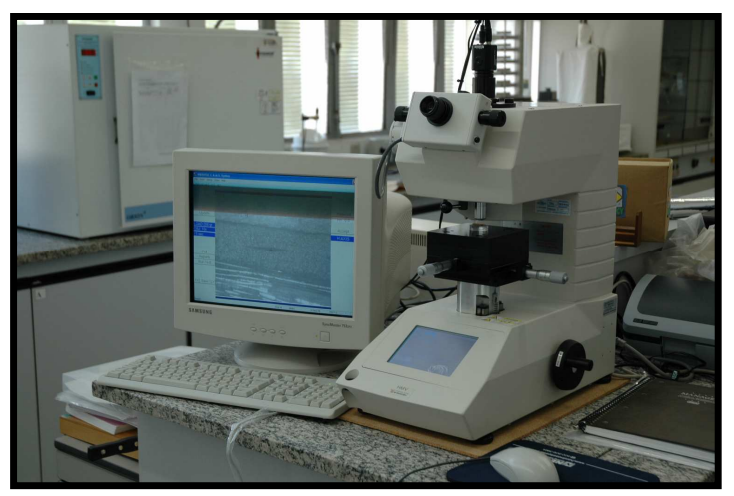

FIGURA 10 - Microdurômetro 
Quando acionado, o penetrador realizou uma compressão na superfície do espécime, gerando uma figura geométrica em forma de losango, visualizada pelo contraste entre a impressão e a superfície (FIGURA 11).

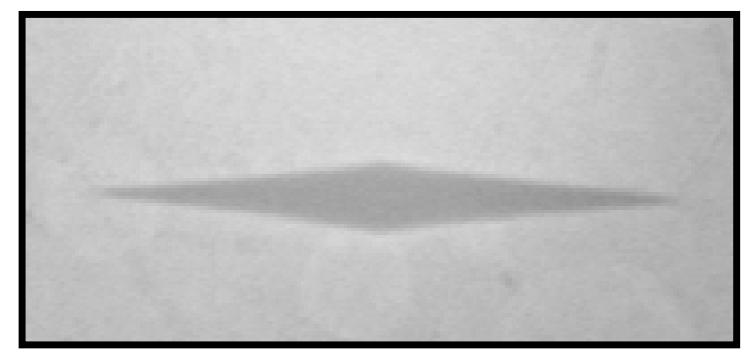

FIGURA 11 - Imagem de uma compressão realizada para avaliação de microdureza em aumento de $10 \mathrm{X}$

O losango possibilita a determinação da microdureza superficial do material a partir da mensuração de sua maior diagonal, cujo valor é aplicado em uma fórmula matemática para obtenção dos resultados. O microdurômetro usado no experimento realiza os cálculos automaticamente, a partir de duas marcas pontilhadas que surgem na tela do computador, sobrepostas aos vértices agudos do losango. Assim, o resultado da dureza KNOOP aparece no monitor do microcomputador através do cálculo feito pelo software da seguinte equação: KHN= C.c/ $\mathrm{d}^{2}$

Sendo: $\mathrm{KHN}=$ valor de dureza Knoop

$\mathrm{C}($ constante $)=14,230$

$\mathrm{c}=25$ gramas

$\mathrm{d}=$ comprimento da maior diagonal da edentação

Foram realizadas quatro compressões por corpo de prova avaliado, sendo uma para cada quadrante. $\mathrm{O}$ valor da microdureza de cada espécime foi dado pela média dos valores das compressões medidas entre os quatro quadrantes.

As mensurações foram feitas numa etapa inicial, previamente ao protocolo de desinfecção, e em outras três ocasiões, referentes a 30, 90 e 180 ciclos de imersão dos corpos de prova. 


\subsubsection{Análise da rugosidade superficial dos corpos de prova}

Para as leituras de rugosidade superficial foi usado o aparelho rugosímetro Hommel Tester T 1000 basic (Hommelwerke GmbH, ref. \# 240851, Schwenningen, Germany), que constitui um aparelho de alta sensibilidade, com ponta apalpadora esférica de diamante, utilizado para medir rugosidade superficial quantitativamente (FIGURA 12). Essa ponta percorre a superfície e é acoplada a uma unidade que processa e interage a informação. O resultado é registrado de imediato por meio de um software (Turbo Datawin-NT Version 1.34, Copwright @ (2001).

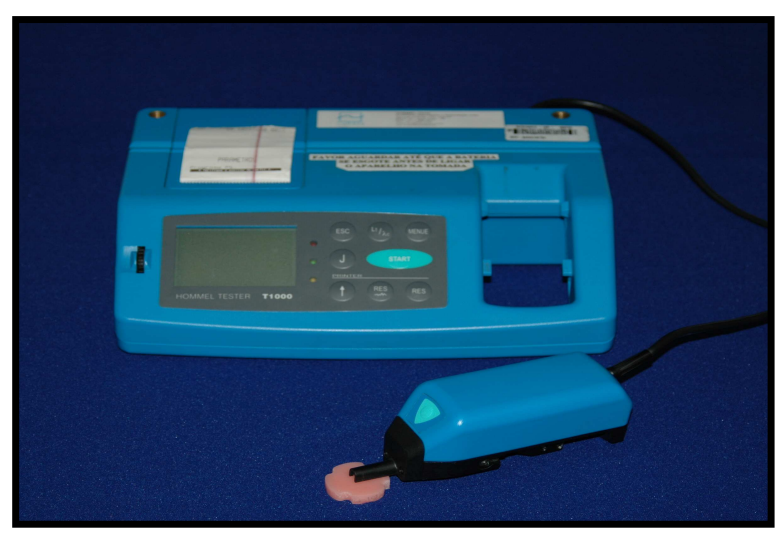

FIGURA 12 - Rugosímetro

As mensurações foram feitas aleatoriamente sobre a superfície da cada quadrante dos corpos de prova, totalizando, 4 leituras para cada espécime. O valor de rugosidade superficial de cada corpo de prova foi determinado pela média aritmética das leituras de cada um dos 4 quadrantes.

O parâmetro $\mathrm{Ra}(\mu \mathrm{m})$ foi escolhido a fim de propiciar condições de comparação com resultados de outros estudos realizados, onde esta escala foi empregada, traduzindo o valor da média aritmética de todas as distâncias absolutas do perfil de rugosidade, dentro de extensão de medida Lm.

Os parâmetros escolhidos foram:

T mínima $=2,5 \mathrm{~mm}$

T máxima $=2,5 \mathrm{~mm}$

$\mathrm{Lt}=4,80 \mathrm{~mm}$

$\mathrm{Lc}=0,800 \mathrm{~mm}$ (cut off)

$\mathrm{Lm}=4,55 \mathrm{~mm}$ 
Sendo:

$\mathrm{T}=$ tolerância (valores extremos a serem considerados nas leituras)

$\mathrm{Lt}=$ limite de tracejamento (extensão real percorrida pela ponta apalpadora)

Lm = limite de medição (extensão considerada na leitura)

Lc $=$ cut off (minimizando a interferência de ondulação da superfície)

\subsection{Protocolo de desinfecção}

O protocolo de desinfecção adotado para a realização deste trabalho seguiu os resultados obtidos em um experimento realizado na Faculdade de Odontologia de Bauru-USP, cujo objetivo foi analisar a efetividade de soluções químicas desinfetantes e o tempo para recolonização de Candida albicans, "in vitro", sobre bases de dentadura, após desinfecção por meio de soluções químicas.

Inicialmente, os desinfetantes, nas concentrações e tempos de imersão utilizados neste estudo, foram selecionados mediante revisão de literatura, a qual demonstrou que estes seriam eficazes quanto à desinfecção dos espécimes testados.

Constatou-se, por meio deste estudo, sinais evidentes de descontaminação dos espécimes de resina acrílica quando os mesmos foram submetidos a desinfecções com soluções de hipoclorito de sódio a $1 \%$ durante 10 minutos; hipoclorito de sódio a $2 \%$ durante 5 minutos; hipoclorito de sódio a 5,25\% durante 5 minutos; glutaraldeído a $2 \%$ durante 10 minutos e gluconato de clorexidina a $4 \%$ durante 10 minutos.

Após a desinfecção, os espécimes foram novamente contaminados com um inóculo de $10^{7}$ células/ml de Candida albicans, pois, segundo CHANDRA et al. ${ }^{24}$, 2001, esta é a quantidade ideal para proporcionar crescimento de biofilme em experimentos “in vitro". Esses espécimes foram avaliados após 24 horas, 3 dias, 7 dias, 15 dias e 30 dias, por meio de lavagem em água estéril, para remoção do biofilme não aderido e posterior raspagem da superfície do espécime de resina acrílica com lâmina de bisturi, a fim de obter, através da raspagem, células de Candida albicans aderidas à resina.

Os resultados deste estudo comprovaram a existência de células vivas de Candida albicans, já aderidas à superfície da resina acrílica, num período de 24 horas após a recontaminação dos espécimes, os quais haviam sido desinfetados, previamente, com as soluções acima citadas. 
Baseado nos resultados deste estudo paralelo, foi determinado que o intervalo de tempo ideal entre um procedimento de desinfecção e outro, visando reproduzir condições clínicas, deveria ser de 24 horas.

\subsection{Desinfecção dos corpos de prova}

A partir da constatação de que as desinfecções, utilizando as soluções químicas analisadas no presente estudo, devem ser realizadas diariamente, desenvolveuse um protocolo de desinfecções seqüenciais, visando simular os procedimentos de desinfecção realizados pelo paciente, todos os dias.

A simulação de 1 mês de desinfecções, referente ao intervalo de 1-30 ciclos de imersão nos desinfetantes, foi dada da seguinte forma: os corpos de prova de cada grupo experimental foram colocados em um frasco plástico contendo $200 \mathrm{ml}$ da solução desinfetante, referente ao grupo experimental em questão, e deixados em imersão durante o tempo estabelecido para cada uma das 5 soluções utilizadas neste estudo.

Decorrido o tempo de imersão no desinfetante, os corpos de prova foram retirados do recipiente contendo a solução e imersos, durante 1 minuto, para lavagem, em outro recipiente contendo $200 \mathrm{ml}$ de água deionizada. O procedimento de lavagem foi repetido 3 vezes, sempre realizando a troca da água. Após a última lavagem, os espécimes foram secos com uma toalha e então, novamente colocados na solução desinfetante, a fim de repetir o procedimento de desinfecção.

Dessa mesma forma, seguiram-se as simulações de 3 e 6 meses de desinfecção diárias, correspondendo ao intervalo de 31-90 e 91-180 ciclos de imersão nos desinfetantes, respectivamente.

Ao final da simulação de 1 mês de desinfecções $\left(30^{\circ}\right.$ ciclo), os corpos de prova foram submetidos aos testes de microdureza e rugosidade superficial. A repetição dos testes também aconteceu ao final das simulações de desinfecção correspondentes a 3 e 6 meses $\left(90^{\circ}\right.$ e $180^{\circ}$ ciclo), a fim de obter parâmetros de comparação entre os diferentes intervalos de avaliação.

Durante todo o período em que os espécimes não estavam sendo submetidos aos processos de desinfecção e aos testes, os mesmos foram armazenados a seco, em recipiente plástico, devidamente tampados, em temperatura ambiente. 


\subsection{Armazenamento dos corpos de prova do grupo controle}

Os corpos de prova correspondentes ao grupo controle mantiveram-se armazenados em recipientes plásticos tampados, imersos em água deionizada. Considerando que um paciente portador de próteses totais as retire da boca durante o sono, e as deixe imersa em água aproximadamente 8 horas por noite, calculou-se que, cada 8 horas de armazenamento em água deionizada, corresponderia a 1 dia do mês (1 ciclo de imersão). Dessa forma, a simulação de armazenamento durante 30 dias (1-30 ciclos de imersão) correspondeu a 240 horas, ou seja, 10 dias de imersão em água deionizada.

No $10^{\circ}$ dia foram realizados os testes de microdureza superficial e rugosidade superficial, para a avaliação de 1 mês (1-30 ciclos de imersão).

Seguindo o mesmo raciocínio, no $30^{\circ}$ dia de armazenamento em água deionizada, foram realizados os testes correspondentes a 3 meses (31-90 ciclos), e no $60^{\circ}$ dia, os testes relacionados a avaliação de 6 meses (91-180 ciclos de imersão).

\subsection{Forma de análise dos resultados}

Os experimentos para a avaliação da microdureza e rugosidade superficial, de cada resina acrílica, foram realizados em delineamento inteiramente casualisado (DIC) em um esquema fatorial $6 \mathrm{X}$ 4, sendo seis soluções utilizadas (água, H1\%, H2\% e H5,25\%, G2\% e GC4\%) e quatro intervalos de avaliação (inicial, 1-30, 31-90 e 91-180 ciclos de imersão). As médias dos dados obtidos foram submetidas à análise de variância (Anova) e suas médias foram comparadas pelo teste de Tukey a 5\% utilizando-se o software OriginPro ${ }^{\circledR}$ 7,5 (ORIGINLAB $^{\circledR}$, 2006. Origin Pro ${ }^{\circledR} 7,5$ Scientific Graphing Analysis Software. Massachusetts, USA, 2006). 

4. Resultados 



\section{Resultados}

Os ensaios de microdureza e rugosidade superficial foram fundamentais para a análise comparativa dessas propriedades, em cada um dos materiais testados, de acordo com as soluções empregadas, bem como para comparar suas alterações ao longo dos intervalos de avaliação.

\subsection{Análise da resina termopolimerizável}

\subsubsection{Análise do teste de microdureza}

Os valores médios de microdureza da resina termopolimerizável, para cada solução estudada, em cada intervalo de avaliação, estão representados no gráfico abaixo (FIGURA 13).

\section{LUCITONE 550 - Microdureza}

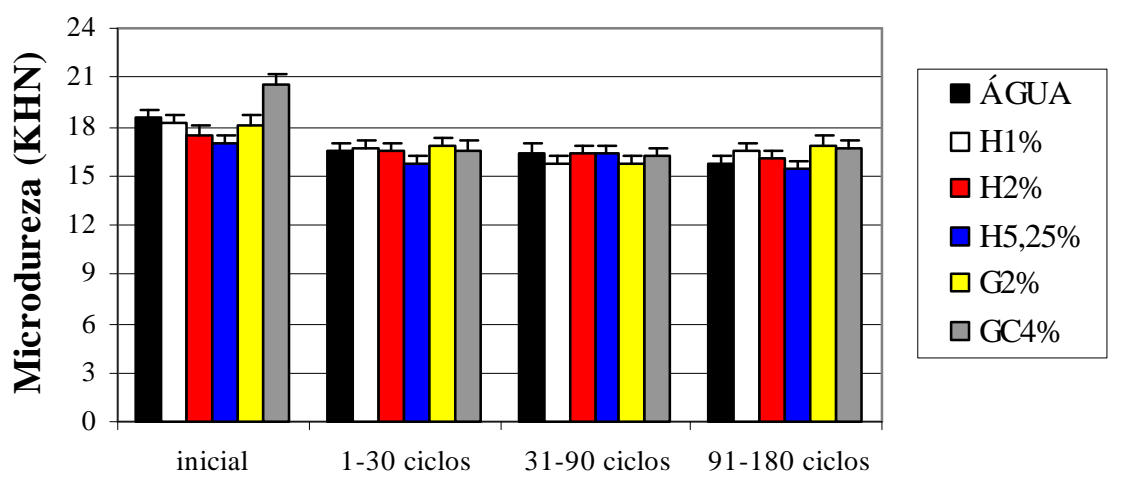

Inte rvalos de avaliação

FIGURA 13 - Média aritmética e desvio padrão dos valores de microdureza (KHN) da resina Lucitone 550 para cada solução estudada, nos diferentes intervalos de avaliação.

Para a análise de microdureza da resina Lucitone 550, a análise de variância indicou a ocorrência de interação significativa entre os fatores soluções e intervalos de avaliação. 
Na TABELA 1 estão apresentadas as comparações, pelo teste de Tukey a $5 \%$, das médias de microdureza (KHN), nas diferentes soluções utilizadas e intervalos de avaliação.

TABELA 1 - Teste de Tukey dos valores médios e desvio padrão da microdureza (KHN) da resina termopolimerizável Lucitone 550, nas diferentes soluções, em cada intervalo de avaliação.

\begin{tabular}{|c|c|c|c|c|c|}
\hline MATERIAL & SOLUÇÃO & INICIAL & 1-30 CICLOS & 31-90 CICLOS & 91-180 CICLOS \\
\hline $\begin{array}{c}\text { LUCITONE } \\
550\end{array}$ & $\begin{array}{c}\text { Água } \\
\text { H 1\% } \\
\text { H 2\% } \\
\text { H 5,25\% } \\
\text { G 2\% } \\
\text { GC 4\% }\end{array}$ & $\begin{array}{c}18,49 \mathrm{aB} \\
\pm \\
0,69 \\
18,23 \mathrm{aB} \\
\pm \\
0,76 \\
17,53 \mathrm{aBC} \\
\pm \\
0,73 \\
17,02 \mathrm{aC} \\
\pm \\
0,83 \\
18,11 \mathrm{aB} \\
\pm \\
1,27 \\
20,61 \mathrm{aA} \\
\pm \\
1,36\end{array}$ & $\begin{array}{c}16,53 \mathrm{~b} \mathrm{AB} \\
\pm \\
0,51 \\
16,62 \mathrm{bAB} \\
\pm \\
0,55 \\
16,45 \mathrm{bAB} \\
\pm \\
0,69 \\
15,68 \mathrm{bB} \\
\pm \\
1,34 \\
16,86 \mathrm{bA} \\
\pm \\
0,71 \\
16,58 \mathrm{bAB} \\
\pm \\
0,30\end{array}$ & $\begin{array}{c}16,44 \mathrm{bA} \\
\pm \\
0,69 \\
15,74 \mathrm{bA} \\
\pm \\
0,28 \\
16,34 \mathrm{bA} \\
\pm \\
0,65 \\
16,40 \mathrm{abA} \\
\pm \\
1,07 \\
15,70 \mathrm{cA} \\
\pm \\
0,96 \\
16,25 \mathrm{bA} \\
\pm \\
0,55\end{array}$ & $\begin{array}{c}15,76 \mathrm{bBC} \\
\pm \\
0,61 \\
16,52 \mathrm{bAB} \\
\pm \\
0,49 \\
16,03 \mathrm{bABC} \\
\pm \\
0,60 \\
15,44 \mathrm{bC} \\
\pm \\
1,26 \\
16,88 \mathrm{bA} \\
\pm \\
0,43 \\
16,71 \mathrm{bAB} \\
\pm \\
0,90\end{array}$ \\
\hline
\end{tabular}

Médias seguidas por letras minúsculas iguais nas colunas não diferem estatisticamente entre si pelo teste de Tukey. Médias seguidas de letras maiúsculas iguais nas linhas não diferem estatisticamente entre si pelo teste de Tukey.

Verifica-se que a água (controle) e as soluções $\mathrm{H} 1 \%, \mathrm{H} 2 \%, \mathrm{H} 5,25 \%, \mathrm{GC} 4 \%$ apresentaram maiores valores médios de microdureza na avaliação inicial, diferindo estatisticamente dos demais intervalos de avaliação. Nestas soluções, ocorreu uma diminuição significativa dos valores médios de microdureza no intervalo entre a avaliação inicial e o $30^{\circ}$ ciclo, sendo que, a partir deste período, não ocorreram diferenças estatisticamente significativas.

Para a solução G2\%, ocorreu uma diminuição significativa dos valores médios de microdureza no intervalo entre a avaliação inicial e o $30^{\circ}$ ciclo, e entre o $31^{\circ}$ $90^{\circ}$ ciclo. A avaliação entre o $91^{\circ}-180^{\circ}$ ciclo apresentou um aumento significativo da microdureza em relação ao $31^{\circ}-90^{\circ}$ ciclo, com valores médios semelhantes ao intervalo entre o $1^{\circ}-30^{\circ}$ ciclo de avaliação. 
$\mathrm{Na}$ comparação entre as soluções estudadas, em cada um dos intervalos de avaliação, observou-se que na avaliação inicial, o maior valor médio de microdureza foi encontrado na solução GC4\% $(20,61 \pm 1,36 \mathrm{KHN})$, diferindo estatisticamente das demais soluções. Os valores médios de microdureza das soluções água, H1\%, H2\% e G2\% foram semelhantes entre si. O menor valor médio foi encontrado na solução H5,25\% (17,02 $\pm 0,83 \mathrm{KHN})$, não ocorrendo diferenças significativas apenas entre este a solução $\mathrm{H} 2 \%$.

No intervalo entre o $1^{\circ}-30^{\circ}$ ciclo de avaliação, somente as soluções $\mathrm{H} 5,25 \%$ e G2\% diferiram estatisticamente entre si, sendo que cada uma delas apresentou valores médios de microdureza semelhantes as demais soluções estudadas.

Os valores médios de microdureza da resina termopolimerizável, em cada solução estudada, foram semelhantes entre si no intervalo entre o $31^{\circ}-90^{\circ}$ ciclo de avaliação. Já entre o $91^{\circ}-180^{\circ}$ ciclo, o maior valor médio de microdureza foi encontrado na solução G2\% (16,88 $\pm 0,43 \mathrm{KHN})$, o qual diferiu estatisticamente apenas das soluções água $(15,76 \pm 0,61 \mathrm{KHN})$ e H5,25\% (15,44 $\pm 1,26 \mathrm{KHN})$. Não ocorreram diferenças significativas entre as soluções água, H1\%, H2\%, GC4\% e entre as soluções água, $\mathrm{H} 2 \%$ e $\mathrm{H} 5,25 \%$. 


\subsubsection{Análise do teste de rugosidade superficial}

As médias dos valores de rugosidade superficial da resina termopolimerizável (Lucitone 550), nas diferentes soluções e intervalos de avaliação estão apresentadas na FIGURA 14.

\section{LUCITONE 550 - Rugosidade Superficial}

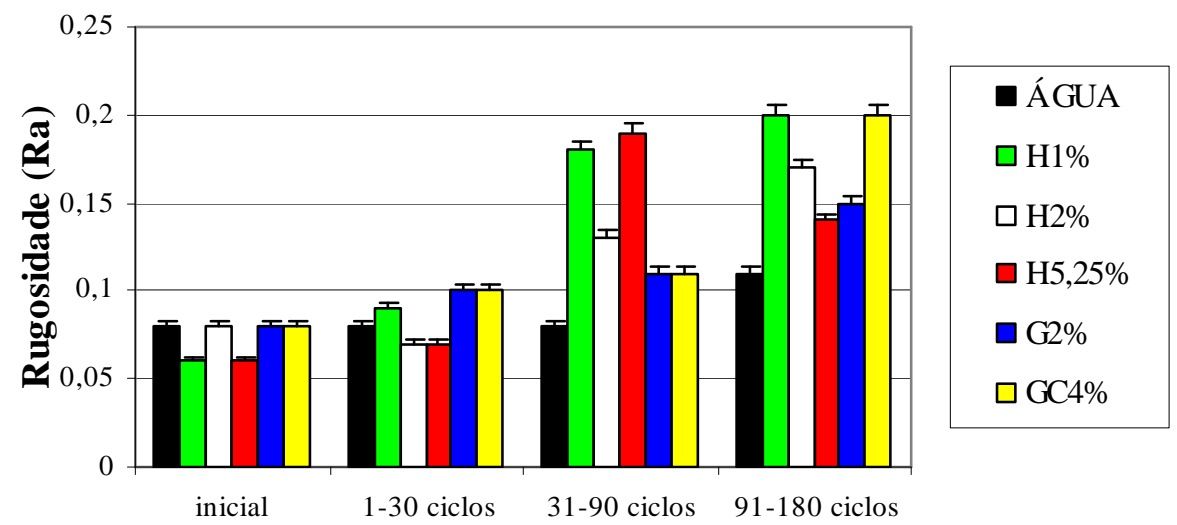

Intervalos de avaliação

FIGURA 14 - Média aritmética e desvio padrão dos valores de rugosidade superficial $(\mu \mathrm{m})$ da resina Lucitone 550, para cada solução estudada, nos diferentes intervalos de avaliação.

Para a análise da rugosidade superficial da resina Lucitone 550, a análise de variância indicou a ocorrência de interação significativa entre os fatores soluções e intervalos de avaliação.

Na TABELA 2 estão apresentadas as comparações pelo teste de Tukey a 5\%, das médias de rugosidade superficial $(\mu \mathrm{m})$, nas diferentes soluções utilizadas e intervalos de avaliação. 
TABELA 2 - Teste de Tukey dos valores médios e desvio padrão da rugosidade superficial $(\mu \mathrm{m})$ da resina termopolimerizável Lucitone 550, nas diferentes soluções, em cada intervalo de avaliação.

\begin{tabular}{|c|c|c|c|c|c|}
\hline MATERIAL & SOLUÇÃO & INICIAL & 1-30 CICLOS & 31-90 CICLOS & 91-180 CICLOS \\
\hline $\begin{array}{c}\text { LUCITONE } \\
\mathbf{5 5 0}\end{array}$ & $\begin{array}{c}\text { H } 2 \% \\
\text { H } 5,25 \% \\
\text { G } 2 \% \\
\text { GC } 4 \%\end{array}$ & $\begin{array}{c}0,08 \mathrm{aA} \\
\pm \\
0,03 \\
0,06 \mathrm{bA} \\
\pm \\
0,01 \\
0,08 \mathrm{cA} \\
\pm \\
0,05 \\
0,06 \mathrm{cA} \\
\pm \\
0,02 \\
0,08 \mathrm{bA} \\
\pm \\
0,04 \\
0,08 \mathrm{bA} \\
\pm \\
0,02\end{array}$ & $\begin{array}{c}0,08 \mathrm{aA} \\
\pm \\
0,02 \\
0,09 \mathrm{bA} \\
\pm \\
0,02 \\
0,07 \mathrm{cA} \\
\pm \\
0,02 \\
0,07 \mathrm{cA} \\
\pm \\
0,01 \\
0,10 \mathrm{bA} \\
\pm \\
0,02 \\
0,10 \mathrm{bA} \\
\pm \\
0,02\end{array}$ & $\begin{array}{c}0,08 \mathrm{aC} \\
\pm \\
0,02 \\
0,18 \mathrm{aA} \\
\pm \\
0,03 \\
0,13 \mathrm{bB} \\
\pm \\
0,02 \\
0,19 \mathrm{aA} \\
\pm \\
0,04 \\
0,11 \mathrm{bBC} \\
\pm \\
0,02 \\
0,11 \mathrm{bBC} \\
\pm \\
0,02\end{array}$ & $\begin{array}{c}0,11 \mathrm{aC} \\
\pm \\
0,06 \\
0,20 \mathrm{aA} \\
\pm \\
0,03 \\
0,17 \mathrm{aAB} \\
\pm \\
0,01 \\
0,14 \mathrm{bBC} \\
\pm \\
0,02 \\
0,15 \mathrm{aB} \\
\pm \\
0,02 \\
0,20 \mathrm{aA} \\
\pm \\
0,02\end{array}$ \\
\hline
\end{tabular}

Médias seguidas por letras minúsculas iguais nas colunas não diferem estatisticamente entre si pelo teste de Tukey. Médias seguidas de letras maiúsculas iguais nas linhas não diferem estatisticamente entre si pelo teste de Tukey.

A análise do teste de Tukey para o efeito de cada solução sobre a rugosidade superficial da resina termopolimerizável, ao longo dos intervalos de avaliação do estudo, demonstrou que os corpos de prova submetidos à água apresentaram valores médios de rugosidade superficial semelhantes, em todos os intervalos de avaliação.

Os valores médios iniciais de rugosidade superficial dos corpos de prova submetidos à solução $\mathrm{H} 1 \%$ não diferiram significativamente dos valores encontrados no intervalo entre o $1^{\circ}-30^{\circ}$ ciclo de avaliação. Ocorreu um aumento significante da rugosidade superficial no intervalo entre o $31^{\circ}-90^{\circ}$ ciclo, o qual manteve-se de forma não significante entre o $91^{\circ}-180^{\circ}$ ciclo.

Para as soluções $\mathrm{H} 2 \%$ e H5,25\%, não ocorreu um aumento significativo da rugosidade superficial, entre a avaliação inicial e o $30^{\circ}$ ciclo. Os valores médios de rugosidade superficial aumentaram significativamente no intervalo entre o $30^{\circ}-90^{\circ}$ ciclo, e entre o $91^{\circ}-180^{\circ}$ ciclo. 
O efeito das soluções $\mathrm{G} 2 \%$ e GC4\% sobre a rugosidade superficial da resina termopolimerizável foi semelhante. Em ambas não ocorreram diferenças significativas no intervalo entre as avaliações iniciais e o $90^{\circ}$ ciclo. Ocorreu diferença significativa apenas entre o $91^{\circ}$ e o $180^{\circ}$ ciclo.

Na comparação entre as diferentes soluções, em cada intervalo de avaliação, os valores médios de rugosidade superficial foram semelhantes na avaliação inicial e no intervalo entre o $1^{\circ}-30^{\circ}$ ciclo. No intervalo entre o $31^{\circ}-90^{\circ}$ ciclo de avaliação, o menor valor médio de rugosidade superficial foi encontrado nos corpos de prova submetidos ao armazenamento em água $(0,08 \pm 0,02 \mu \mathrm{m})$ e este valor foi semelhante aos valores da rugosidade de $\mathrm{G} 2 \%$ e $\mathrm{GC} 4 \%(0,11 \pm 0,02 \mu \mathrm{m})$. Os valores médios de rugosidade foram semelhantes entre as soluções H1\% e H5,25\% e entre as soluções H2\%, G2\% e GC4\%.

No intervalo entre o $91^{\circ}-180^{\circ}$ ciclo, o menor valor médio de rugosidade superficial foi encontrado nos corpos de prova submetidos à imersão em água $(0,11 \pm$ $0,06 \mu \mathrm{m})$, e este foi semelhante à $\mathrm{H} 5,25 \%$. Os maiores valores de rugosidade superficial foram encontrados nos corpos de prova submetidos à desinfecção com hipoclorito de sódio a 1\% (H1\%) e com gluconato de clorexidina a 4\% (GC4\%). Não ocorreram diferenças significativas entre essas soluções e a solução $\mathrm{H} 2 \%$, e nem entre as soluções $\mathrm{H} 2 \%, \mathrm{H} 5,25 \%$ e $\mathrm{G} 2 \%$.

\subsection{Análise das resinas autopolimerizáveis}

\subsubsection{Análise do teste de microdureza da resina Jet}

As médias dos valores de microdureza da resina autopolimerizável Jet, para cada uma das soluções testadas, nos intervalos inicial, 1-30, 31-90 e 91-180 ciclos, estão apresentadas na FIGURA 15. 


\section{JET - Microdureza}

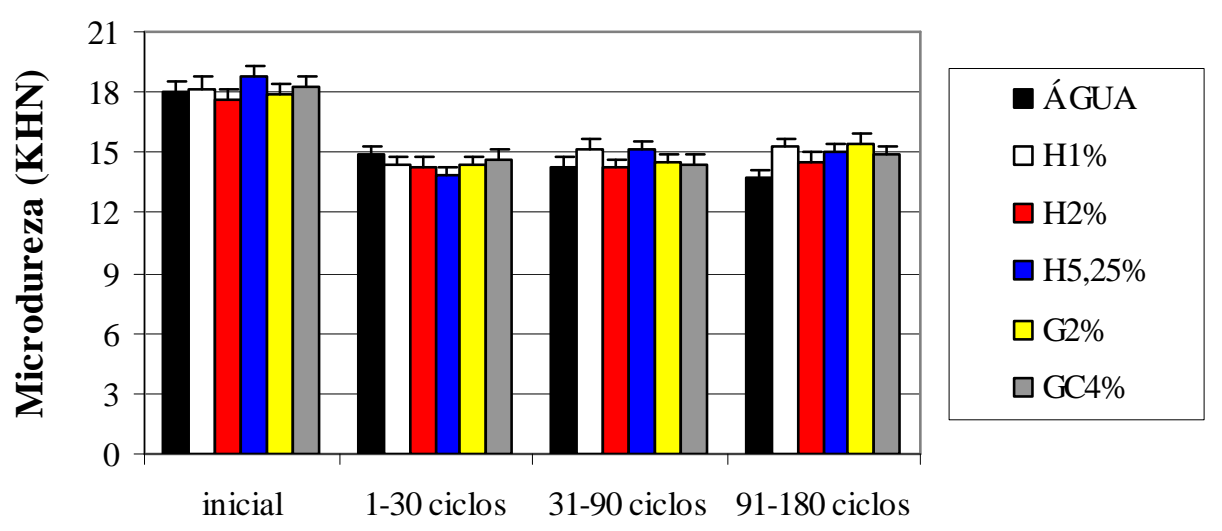

Intervalos de avaliação

FIGURA 15 - Média aritmética e desvio padrão dos valores de microdureza (KHN) da resina Jet, para cada solução estudada, nos diferentes intervalos de avaliação.

Para a análise da microdureza da resina Jet, a análise de variância indicou a ocorrência de interação significativa entre os fatores soluções e intervalos de avaliação.

Na TABELA 3 estão apresentadas as comparações pelo teste de Tukey a 5\%, das médias de microdureza $(\mathrm{KHN})$, nas diferentes soluções utilizadas e intervalos de avaliação. 
TABELA 3 - Teste de Tukey dos valores médios e desvio padrão da microdureza (KHN) da resina autopolimerizável Jet, nas diferentes soluções, em cada intervalo de avaliação.

\begin{tabular}{|c|c|c|c|c|c|}
\hline & SOLUÇÃO & INICIAL & 1-30 CICLOS & 31-90 CICLOS & 91-180 CICLOS \\
\hline JET & $\begin{array}{c}\text { H } 2 \% \\
\text { H } 5,25 \% \\
\text { G } 2 \% \\
\text { GC } 4 \%\end{array}$ & $\begin{array}{c}18,05 \mathrm{aA} \\
\pm \\
1,45 \\
18,21 \mathrm{aA} \\
\pm \\
1,76 \\
17,65 \mathrm{aA} \\
\pm \\
1,63 \\
18,74 \mathrm{aA} \\
\pm \\
0,47 \\
17,87 \mathrm{aA} \\
\pm \\
0,80 \\
18,23 \mathrm{aA} \\
\pm \\
0,76\end{array}$ & $\begin{array}{c}14,87 \mathrm{bA} \\
\pm \\
0,56 \\
14,34 \mathrm{bA} \\
\pm \\
0,75 \\
14,29 \mathrm{bA} \\
\pm \\
0,62 \\
13,86 \mathrm{cA} \\
\pm \\
0,82 \\
14,34 \mathrm{cA} \\
\pm \\
0,92 \\
14,71 \mathrm{bA} \\
\pm \\
0,92\end{array}$ & $\begin{array}{c}14,30 \mathrm{bcA} \\
\pm \\
1,10 \\
15,22 \mathrm{bA} \\
\pm \\
0,72 \\
14,23 \mathrm{bA} \\
\pm \\
0,84 \\
15,11 \mathrm{bA} \\
\pm \\
1,08 \\
14,51 \mathrm{bcA} \\
\pm \\
0,90 \\
14,44 \mathrm{bA} \\
\pm \\
0,55\end{array}$ & $\begin{array}{c}13,75 \mathrm{cB} \\
\pm \\
0,95 \\
15,26 \mathrm{bA} \\
\pm \\
0,63 \\
14,58 \mathrm{bAB} \\
\pm \\
0,43 \\
15,00 \mathrm{bA} \\
\pm \\
1,03 \\
15,43 \mathrm{bA} \\
\pm \\
0,39 \\
14,89 \mathrm{bAB} \\
\pm \\
0,59\end{array}$ \\
\hline
\end{tabular}

Médias seguidas por letras minúsculas iguais nas colunas não diferem estatisticamente entre si pelo teste de Tukey. Médias seguidas de letras maiúsculas iguais nas linhas não diferem estatisticamente entre si pelo teste de Tukey.

Analisando a TABELA 3, verifica-se que para as soluções água e G2\%, ocorreu uma diminuição significativa dos valores médios de microdureza entre a avaliação inicial e os demais intervalos de avaliação. Os maiores valores médios foram identificados na avaliação inicial, que diferiram significativamente dos valores médios do encontrados no intervalo $1^{\circ}-30^{\circ}$ ciclo. Não ocorreram diferenças significativas entre os intervalos 1-30 e 31-90 ciclos. Embora os valores encontrados, para as soluções água e G2\%, no intervalo 91-180 ciclos, tenham diferido estatisticamente somente dos valores da avaliação inicial e do intervalo 1-30 ciclos, essas soluções provocaram alterações diferentes de microdureza, ao longo do estudo. Nota-se que a água provocou a redução gradativa da microdureza, enquanto o glutaraldeído causou uma redução da microdureza inicialmente $\left(1^{\circ}-30^{\circ}\right.$ ciclo), acompanhada de um aumento significativo após 90 ciclos de imersão.

A desinfecção dos corpos de prova com as soluções $\mathrm{H} 1 \%$, H2\% e GC4\% causou diminuição significativa dos valores médios de microdureza entre a avaliação inicial e os demais intervalos de avaliação. Nestas soluções, os valores de microdureza sofreram uma redução entre a avaliação inicial e o intervalo entre o $1^{\circ}-30^{\circ}$ ciclo, 
contudo, entre os intervalos 1-30, 31-90 e 91-180 ciclos, não ocorreram diferenças significativas. Dessa forma, a microdureza dos corpos de prova da resina Jet se estabilizou após 30 ciclos de desinfecção com hipoclorito de sódio a 1\%, $2 \%$ e gluconato de clorexidina a $4 \%$.

Uma redução significativa dos valores médios de microdureza entre a avaliação inicial e os demais intervalos de avaliação foi causada também pela solução H5,25\%. Embora os valores médios de microdureza tenham sofrido uma diminuição significativa entre a avaliação inicial e o intervalo 1-30 ciclos, a partir desta avaliação, ocorreu um aumento significativo da microdureza, o qual manteve-se no intervalo entre o $91^{\circ}-180^{\circ}$ ciclo, porém, de forma não significante.

$\mathrm{Na}$ comparação entre os valores médios de microdureza das diferentes soluções utilizadas, em cada um dos intervalos de avaliação, ocorreram diferenças significativas apenas para o $180^{\circ}$ ciclo.

Neste período, os maiores valores médios de microdureza foram obtidos para as soluções $\mathrm{G} 2 \%$, $\mathrm{H} 1 \%$ e $\mathrm{H} 5,25 \%$, não ocorrendo diferenças significativas entre eles. O menor valor médio de microdureza foi encontrado nos corpos de prova submetidos ao armazenamento em água $(13,75 \pm 0,95 \mathrm{KHN})$, no entanto, este valor não diferiu significativamente dos valores médios obtidos nas soluções $\mathrm{H} 2 \%$ e GC4\%. 


\subsubsection{Análise do teste de rugosidade superficial da resina Jet}

Na FIGURA 16 estão apresentadas as médias dos valores de rugosidade superficial da resina autopolimerizável (Jet), nas diferentes soluções utilizadas e intervalos de avaliação.

\section{JET - Rugosidade Superficial}

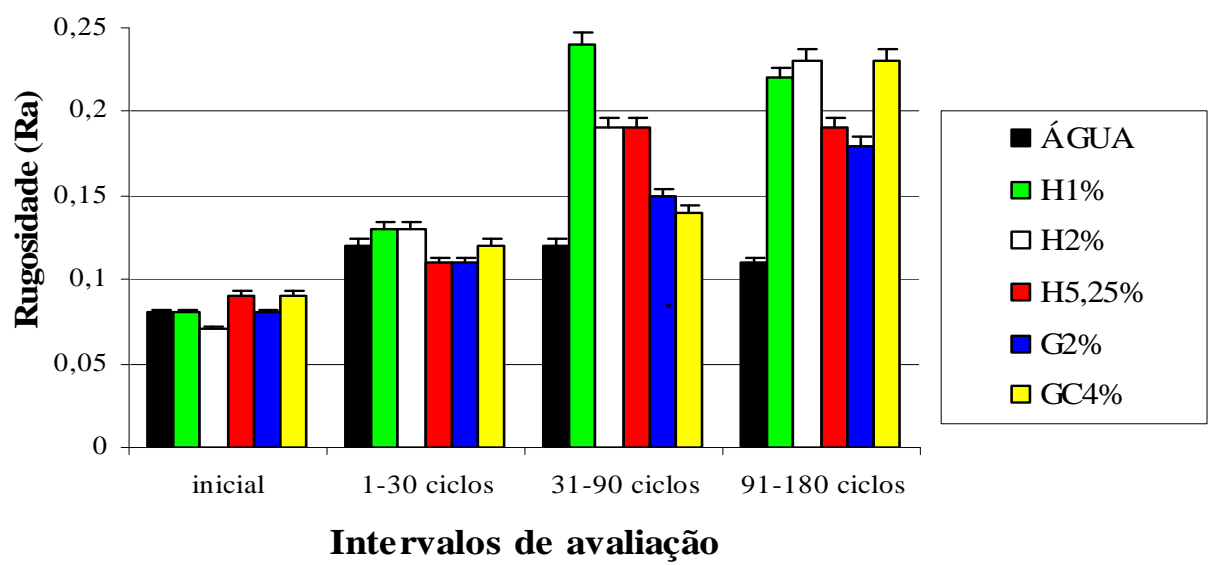

FIGURA 16 - Média aritmética e desvio padrão dos valores de rugosidade superficial $(\mu \mathrm{m})$ da resina Jet, para cada solução estudada, nos diferentes intervalos de avaliação.

Para a análise da rugosidade superficial da resina Jet, a análise de variância indicou a ocorrência de interação significativa entre os fatores soluções e intervalo de avaliação.

Na TABELA 4 estão apresentadas as comparações pelo teste de Tukey a 5\%, das médias de rugosidade superficial $(\mu \mathrm{m})$, nas diferentes soluções utilizadas e intervalos de avaliação. 
TABELA 4 - Teste de Tukey dos valores médios e desvio padrão da rugosidade superficial $(\mu \mathrm{m})$ da resina autopolimerizável Jet, nas diferentes soluções, em cada intervalo de avaliação.

\begin{tabular}{|c|c|c|c|c|c|}
\hline MATERIAL & SOLUÇÃO & INICIAL & 1-30 CICLOS & 31-90 CICLOS & 91-180 CICLOS \\
\hline & Água & $\begin{array}{c}0,08 \mathrm{bA} \\
\pm \\
0,04\end{array}$ & $\begin{array}{c}0,12 \mathrm{aA} \\
\pm \\
0,03\end{array}$ & $\begin{array}{c}0,12 \mathrm{aC} \\
\pm \\
0,02\end{array}$ & $\begin{array}{c}0,11 \mathrm{abC} \\
\pm \\
0,03\end{array}$ \\
\hline & H $1 \%$ & $\begin{array}{c}0,08 \mathrm{cA} \\
\pm \\
0,02\end{array}$ & $\begin{array}{c}0,13 \mathrm{bA} \\
\pm \\
0,02\end{array}$ & $\begin{array}{c}0,24 \mathrm{aA} \\
\pm \\
0,03\end{array}$ & $\begin{array}{c}0,22 \mathrm{aAB} \\
\pm \\
0,03\end{array}$ \\
\hline \multirow[t]{4}{*}{ JET } & H $2 \%$ & $\begin{array}{c}0,07 \mathrm{cA} \\
\pm \\
0,01\end{array}$ & $\begin{array}{c}0,12 \mathrm{bA} \\
\pm \\
0,03\end{array}$ & $\begin{array}{c}0,19 \mathrm{aB} \\
\pm \\
0,03\end{array}$ & $\begin{array}{c}0,23 \mathrm{aAB} \\
\pm \\
0,04\end{array}$ \\
\hline & Н $5,25 \%$ & $\begin{array}{c}0,09 \mathrm{bA} \\
\pm \\
0,03\end{array}$ & $\begin{array}{c}0,11 \mathrm{bA} \\
\pm \\
0,03\end{array}$ & $\begin{array}{c}0,19 \mathrm{aB} \\
\pm \\
0,03\end{array}$ & $\begin{array}{c}0,19 \mathrm{aAB} \\
\pm \\
0,02 \\
\end{array}$ \\
\hline & G $2 \%$ & $\begin{array}{c}0,08 \mathrm{bA} \\
\pm \\
0,02\end{array}$ & $\begin{array}{c}0,11 \mathrm{bA} \\
\pm \\
0,02\end{array}$ & $\begin{array}{c}0,15 \mathrm{aBC} \\
\pm \\
0,02\end{array}$ & $\begin{array}{c}0,18 \mathrm{aB} \\
\pm \\
0,03\end{array}$ \\
\hline & GC $4 \%$ & $\begin{array}{c}0,09 \mathrm{cA} \\
\pm \\
0,03\end{array}$ & $\begin{array}{c}0,12 \text { bcA } \\
\pm \\
0,04\end{array}$ & $\begin{array}{c}0,14 \mathrm{bC} \\
\pm \\
0,03\end{array}$ & $\begin{array}{c}0,23 \mathrm{aA} \\
\pm \\
0,04\end{array}$ \\
\hline
\end{tabular}

Médias seguidas por letras minúsculas iguais nas colunas não diferem estatisticamente entre si pelo teste de Tukey. Médias seguidas de letras maiúsculas iguais nas linhas não diferem estatisticamente entre si pelo teste de Tukey.

De acordo com os dados da TABELA 4, os corpos de prova da resina Jet submetidos à imersão em água apresentaram valores médios iniciais inferiores aos demais intervalos de avaliação, porém, ocorreram diferenças significativas apenas entre os valores médios da avaliação inicial e os intervalos 1-30 e 31-90 ciclos.

O efeito das desinfecções com as soluções H1\% e H2\% sobre o aumento dos valores de rugosidade superficial foi semelhante. Em ambas soluções, os valores médios iniciais foram menores $(0,08 \pm 0,02$ e $0,07 \pm 0,01 \mu \mathrm{m})$ e diferiram estatisticamente dos demais intervalos. Ocorreu um aumento significativo dos valores médios de rugosidade superficial da avaliação inicial em relação ao intervalo 1-30 ciclos e deste em relação aos dois últimos intervalos de avaliação. No intervalo entre o $31^{\circ}-90^{\circ}$ e $91^{\circ}-180^{\circ}$ ciclo não foi observado aumento significativo da rugosidade.

As soluções $\mathrm{H} 5,25 \%$ e G2\% não causaram aumento significativo dos valores médios de rugosidade superficial entre a avaliação inicial e o intervalo 1-30 ciclos, mas, esse aumento foi significativo entre o intervalo 1-30 e o 31-90 ciclos. A partir desta avaliação, o aumento dos valores médios manteve-se de forma não significativa. 
Os valores médios iniciais de rugosidade superficial dos corpos de prova da resina Jet submetidos à desinfecção com gluconato de clorexidina a 4\% (GC4\%), foram estatisticamente semelhantes aos do intervalo entre o $1^{\circ}-30^{\circ}$ ciclo. Não ocorreram diferenças significativas entre os intervalos 1-30 e 31-90 ciclos, embora, tenha ocorrido um aumento significativo dos valores médios entre o intervalo 31-90 e 91-180 ciclos, com variação de $0,14 \pm 0,03$ a $0,23 \pm 0,04 \mu \mathrm{m}$.

Ao analisar as comparações entre as diferentes soluções empregadas, em cada intervalo de avaliação, observou-se que, tanto para a avaliação inicial quanto para o intervalo entre $\mathrm{o} 1^{\circ}-30^{\circ}$ ciclo, as soluções testadas não apresentaram diferenças significativas nos valores médios de rugosidade superficial. O mesmo não aconteceu nas avaliações do intervalo 31-90 e 91-180 ciclos.

No intervalo entre o $31^{\circ}-90^{\circ}$ ciclo, o menor valor médio de rugosidade superficial foi encontrado nos corpos de prova imersos em água $(0,12 \pm 0,02 \mu \mathrm{m})$ que não diferiu significativamente dos valores encontrados para as soluções G2\% e GC4\%. Os valores médios das soluções $\mathrm{G} 2 \%$, H2\% e H5,25\% também foram semelhantes. A solução $\mathrm{H} 1 \%$ apresentou o maior valor médio de rugosidade superficial $(0,24 \pm$ $0,03 \mu \mathrm{m})$, diferindo significativamente das outras soluções testadas.

No intervalo entre o $91^{\circ}-180^{\circ}$ ciclo de avaliação, o menor valor médio foi encontrado nos corpos de prova submetidos à imersão em água $(0,11 \pm 0,03 \mu \mathrm{m})$, ocorrendo diferenças significativas entre esta e as demais soluções. Valores médios semelhantes foram encontrados para $\mathrm{H} 1 \%, \mathrm{H} 2 \%, \mathrm{H} 5,25 \%$ e $\mathrm{G} 2 \%$, assim como as soluções GC4\%, H1\%, H2\% e H5,25\%. 


\subsubsection{Análise do teste de microdureza da resina Kooliner}

As médias dos valores de microdureza da resina autopolimerizável (Kooliner), para cada solução testada, nos diferentes intervalos de avaliação, estão representadas na FIGURA 17.

KOOLINER - Microdureza

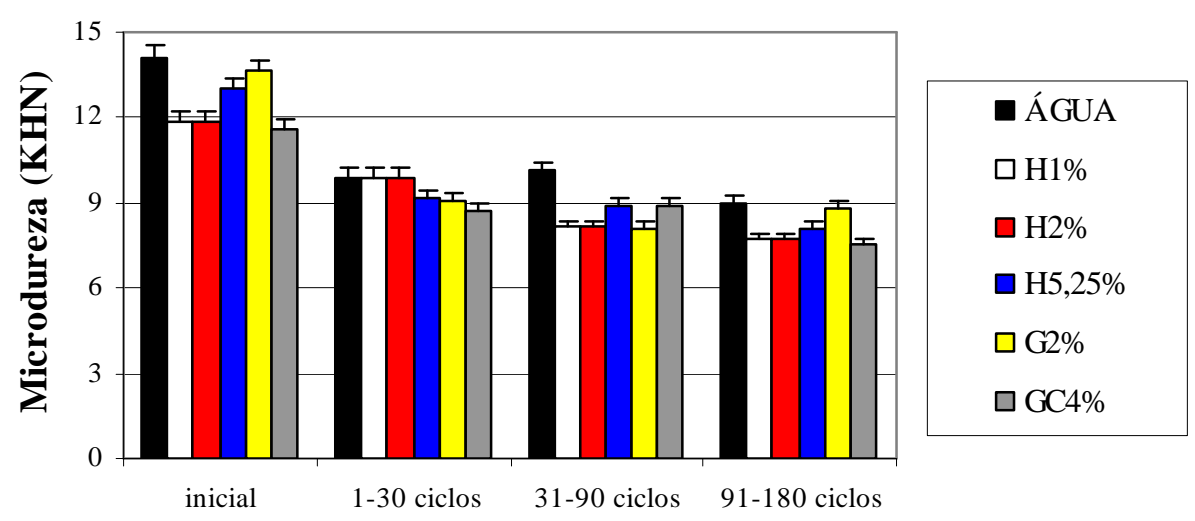

Intervalos de avaliação

FIGURA 17 - Média aritmética e desvio padrão dos valores de microdureza (KHN) da resina Kooliner, para cada solução estudada, nos diferentes intervalos de avaliação.

Para a análise da microdureza da resina Kooliner, a análise de variância indicou a ocorrência de interação significativa entre os fatores soluções e intervalo de avaliação.

Na TABELA 5 estão apresentadas as comparações, pelo teste de Tukey a $5 \%$, das médias de microdureza (KHN), nas diferentes soluções utilizadas e intervalos de avaliação. 
TABELA 5 - Teste de Tukey dos valores médios e desvio padrão da microdureza (KHN) da resina autopolimerizável Kooliner, nas diferentes soluções, em cada intervalo de avaliação.

\begin{tabular}{|c|c|c|c|c|c|}
\hline MATERIAL & SOLUÇÃOO & INICIAL & 1-30 CICLOS & 31-90 CICLOS & 91-180 CICLOS \\
\hline KOOLINER & $\begin{array}{c}\text { H } 2 \% \\
\text { H } 5,25 \% \\
\text { G } 2 \% \\
\text { GC } 4 \%\end{array}$ & $\begin{array}{c}14,09 \mathrm{aA} \\
\pm \\
1,63 \\
12,74 \mathrm{aBC} \\
\pm \\
1,06 \\
11,9 \mathrm{aBC} \\
\pm \\
1,06 \\
12,99 \mathrm{aAB} \\
\pm \\
0,96 \\
13,32 \mathrm{aA} \\
\pm \\
1,40 \\
11,56 \mathrm{aC} \\
\pm \\
1,11\end{array}$ & $\begin{array}{c}9,90 \mathrm{bA} \\
\pm \\
1,03 \\
8,96 \mathrm{bA} \\
\pm \\
0,53 \\
9,91 \mathrm{bA} \\
\pm \\
0,53 \\
9,15 \mathrm{bA} \\
\pm \\
0,83 \\
8,92 \mathrm{bA} \\
\pm \\
0,67 \\
8,72 \mathrm{bcA} \\
\pm \\
0,84\end{array}$ & $\begin{array}{c}10,13 \mathrm{bA} \\
\pm \\
0,89 \\
7,88 \mathrm{cB} \\
\pm \\
0,96 \\
8,13 \mathrm{cB} \\
\pm \\
0,96 \\
8,92 \mathrm{bAB} \\
\pm \\
0,70 \\
8,11 \mathrm{bB} \\
\pm \\
0,76 \\
8,92 \mathrm{bAB} \\
\pm \\
0,87\end{array}$ & $\begin{array}{c}9,02 \mathrm{bA} \\
\pm \\
0,77 \\
7,70 \mathrm{cAB} \\
\pm \\
0,51 \\
7,70 \mathrm{cAB} \\
\pm \\
0,51 \\
8,09 \mathrm{bAB} \\
\pm \\
0,90 \\
8,79 \mathrm{bAB} \\
\pm \\
0,93 \\
7,52 \mathrm{cB} \\
\pm \\
0,88\end{array}$ \\
\hline
\end{tabular}

Médias seguidas por letras minúsculas iguais nas colunas não diferem estatisticamente entre si pelo teste de Tukey. Médias seguidas de letras maiúsculas iguais nas linhas não diferem estatisticamente entre si pelo teste de Tukey.

A análise da TABELA 5 demonstra uma redução significativa dos valores médios iniciais de microdureza em relação as demais avaliações, além de redução não significativa desses valores, entre os intervalos 1-30, 31-90 e 91-180 ciclos, para as soluções $\mathrm{H} 5,25 \%$ e G2\%.

As soluções $\mathrm{H} 1 \%$ e $\mathrm{H} 2 \%$ apresentaram comportamento semelhante em relação à diminuição dos valores médios de microdureza. Para ambos, os valores médios da avaliação inicial diferiram significativamente dos demais intervalos de avaliação; ocorreu uma diminuição significativa destes valores entre a avaliação inicial e o intervalo 1-30 ciclos, e deste para os demais intervalos. A redução dos valores médios de microdureza entre os intervalos 31-90 e 91-180 ciclos não foi significativa.

A solução GC4\% apresentou uma redução dos valores médios de microdureza entre a avaliação inicial e os demais intervalos de avaliação. Os valores obtidos no intervalo entre o $1^{\circ}-30^{\circ}$ ciclo foram semelhantes ao intervalo entre o $31^{\circ}-90^{\circ}$ ciclo. Ocorreram diferenças significativas na redução da microdureza, entre os intervalos 31-90 e 91-180 ciclos. 
$\mathrm{Na}$ avaliação inicial, os valores médios de microdureza foram semelhantes entre as soluções água, $\mathrm{H} 5,25 \%$ e G2\%; entre $\mathrm{H} 1 \%, \mathrm{H} 2 \%$ e $\mathrm{H} 5,25 \%$; e entre $\mathrm{H} 1 \%, \mathrm{H} 2 \%$ e GC4\%.

No intervalo entre o $1^{\circ}-30^{\circ}$ ciclo de avaliação, os valores médios de microdureza foram semelhantes, independentemente da solução utilizada. No intervalo entre o $31^{\circ}-90^{\circ}$ ciclo, a solução água apresentou maior média de microdureza $(10,13 \pm$ $0,89 \mathrm{KHN}$ ) diferindo significativamente apenas das soluções $\mathrm{H} 1 \%, \mathrm{H} 2 \%$ e $\mathrm{G} 2 \%$, e no intervalo entre o $91^{\circ}-180^{\circ}$ ciclo $(9,02 \pm 0,77 \mathrm{KHN})$, diferiu apenas do grupo GC4\%.

Nos intervalos 31-90 e 91-180 ciclos não ocorreram diferenças significativas entre os valores médios de microdureza dos grupos experimentais estudados.

\subsubsection{Análise do teste de rugosidade superficial da resina Kooliner}

Na FIGURA 18, encontram-se as médias dos valores de rugosidade superficial da resina autopolimerizável Kooliner, para cada solução testada, nos intervalos de análise inicial, 1-30, 31-90 e 91-180 ciclos.

\section{KOOLINER - Rugosidade}

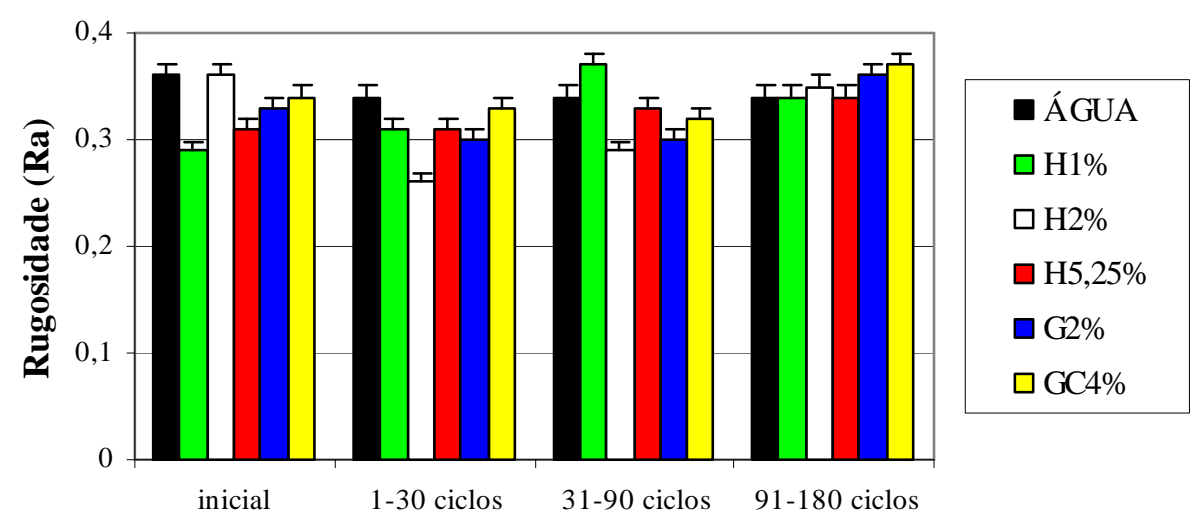

Intervalos de avaliação

FIGURA 18 - Média e desvio padrão dos valores de rugosidade superficial $(\mu \mathrm{m})$ da resina Kooliner, para cada solução estudada, nos diferentes intervalos de avaliação.

Para a análise da rugosidade superficial da resina Kooliner, na análise de variância não ocorreu interação significativa entre os fatores avaliados. 
Na TABELA 6 estão apresentados, a média e desvio padrão dos valores de rugosidade superficial $(\mu \mathrm{m})$, nas diferentes soluções utilizadas e intervalos de avaliação.

TABELA 6 - Média e desvio padrão dos valores de rugosidade superficial $(\mu \mathrm{m})$ da resina autopolimerizável Kooliner, nas diferentes soluções, em cada intervalo de avaliação.

\begin{tabular}{c|c|c|c|c|c}
\hline \multirow{2}{*}{ MATERIAL } & SOLUÇão & INICIAL & $\mathbf{1 - 3 0}$ CICLOS & $\mathbf{3 1 - 9 0 ~ C I C L O S}$ & 91-180 CICLOS \\
\hline \multirow{3}{*}{ KOOLINER $^{\text {ns }}$} & Água & $0,36 \pm 0,08$ & $0,34 \pm 0,04$ & $0,34 \pm 0,06$ & $0,34 \pm 0,05$ \\
& H 1\% & $0,29 \pm 0,07$ & $0,31 \pm 0,07$ & $0,37 \pm 0,06$ & $0,34 \pm 0,06$ \\
& H 2\% & $0,36 \pm 0,07$ & $0,26 \pm 0,05$ & $0,29 \pm 0,04$ & $0,35 \pm 0,04$ \\
& H 5,25\% & $0,31 \pm 0,09$ & $0,31 \pm 0,08$ & $0,33 \pm 0,07$ & $0,34 \pm 0,05$ \\
& G 2\% & $0,33 \pm 0,13$ & $0,30 \pm 0,10$ & $0,30 \pm 0,10$ & $0,36 \pm 0,08$ \\
& GC 4\% & $0,34 \pm 0,10$ & $0,33 \pm 0,09$ & $0,32 \pm 0,08$ & $0,37 \pm 0,05$ \\
\hline
\end{tabular}

ns não significativo.

\subsubsection{Análise do teste de microdureza da resina Tokuyama Rebase} II fast

As médias e desvio-padrão dos valores de microdureza da resina autopolimerizável (Tokuyama Rebase II fast), para cada um das soluções testadas, nos intervalos de análise, estão apresentadas no gráfico abaixo (FIGURA 19).

\section{TOKUYAMA REBASE II FAST- Microdureza}

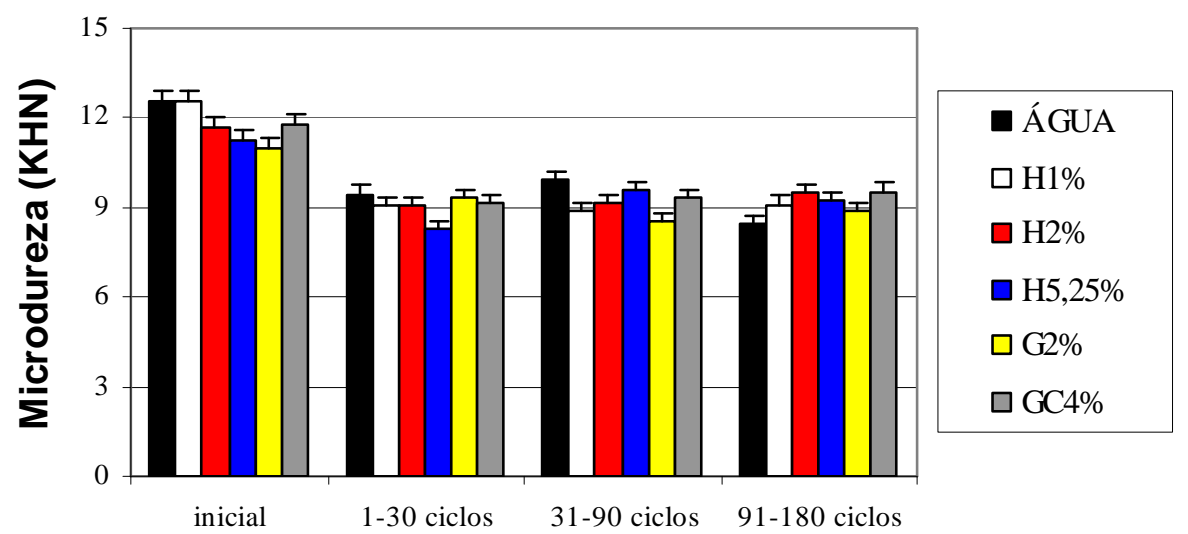

Intervalos de avaliação

FIGURA 19 - Média e desvio padrão dos valores de microdureza (KHN) da resina Tokuyama Rebase II fast, para cada solução estudada, nos diferentes intervalos de avaliação. 
Para a análise da microdureza da resina Tokuyama Rebase II fast, a análise de variância indicou a ocorrência de interação significativa entre os fatores soluções e intervalo de avaliação.

Na TABELA 7 estão apresentados, as médias e desvio padrão dos valores de microdureza (KHN), nas diferentes soluções utilizadas e intervalos de avaliação.

TABELA 7 - Teste de Tukey dos valores médios e desvio padrão da microdureza (KHN) da resina autopolimerizável Tokuyama Rebase II fast, de acordo com as diferentes soluções, em cada intervalo de avaliação.

\begin{tabular}{|c|c|c|c|c|c|}
\hline MATERIAL & SOLUÇÃO & INICIAL & 1-30 CICLOS & 31-90 CICLOS & 91-180 CICLOS \\
\hline $\begin{array}{c}\text { TOKUYAMA } \\
\text { REBASE II } \\
\text { FAST }\end{array}$ & $\begin{array}{c}\text { H } 5,25 \% \\
\text { G } 2 \%\end{array}$ & $\begin{array}{c}12,57 \mathrm{aA} \\
\pm \\
0,94 \\
12,54 \mathrm{aA} \\
\pm \\
0,80 \\
11,66 \mathrm{aBC} \\
\pm \\
0,58 \\
\\
11,27 \mathrm{aBC} \\
\pm \\
0,41 \\
11,02 \mathrm{aC} \\
\pm \\
0,85 \\
11,74 \mathrm{aB} \\
\pm \\
0,64\end{array}$ & $\begin{array}{c}9,45 \mathrm{bA} \\
\pm \\
0,26 \\
9,07 \mathrm{bA} \\
\pm \\
0,12 \\
9,06 \mathrm{bA} \\
\pm \\
0,32 \\
\\
8,28 \mathrm{cB} \\
\pm \\
0,39 \\
9,34 \mathrm{bA} \\
\pm \\
0,34 \\
9,13 \mathrm{bA} \\
\pm \\
0,40 \\
\end{array}$ & $\begin{array}{c}9,91 \mathrm{bA} \\
\pm \\
0,74 \\
8,91 \mathrm{bCD} \\
\pm \\
0,79 \\
9,15 \mathrm{bBC} \\
\pm \\
0,37 \\
\\
9,60 \mathrm{bAB} \\
\pm \\
0,60 \\
8,57 \mathrm{cD} \\
\pm \\
0,35 \\
9,32 \mathrm{bABC} \\
\pm \\
0,33\end{array}$ & $\begin{array}{c}8,47 \mathrm{cB} \\
\pm \\
0,27 \\
9,10 \mathrm{bAB} \\
\pm \\
0,45 \\
9,49 \mathrm{bA} \\
\pm \\
0,50 \\
\\
9,24 \mathrm{bA} \\
\pm \\
0,31 \\
8,90 \mathrm{bcAB} \\
\pm \\
0,25 \\
9,53 \mathrm{bA} \\
\pm \\
0,34 \\
\end{array}$ \\
\hline
\end{tabular}

Médias seguidas por letras minúsculas iguais nas colunas não diferem estatisticamente entre si pelo teste de Tukey. Médias seguidas de letras maiúsculas iguais nas linhas não diferem estatisticamente entre si pelo teste de Tukey.

Os dados apresentados na TABELA 7 indicam que o valor médio da microdureza dos corpos de prova da resina Tokuyama Rebase II fast submetidos ao armazenamento em água, diferiu significativamente entre a avaliação inicial e os demais intervalos. Ocorreu uma diminuição significativa da microdureza entre a avaliação inicial e o intervalo 1-30 ciclos. Tal diminuição não se manteve no intervalo 31-90 ciclos, voltando a ocorrer de forma significativa no intervalo 91-180 ciclos.

Para os grupos $\mathrm{H} 1 \%, \mathrm{H} 2 \%$ e GC4\%, os valores médios iniciais de microdureza foram superiores aos demais intervalos de avaliação, diferindo destes 
significativamente. O efeito dessas soluções foi semelhante ao longo dos intervalos, não ocorrendo diferenças significativas entre o $1^{\circ}-30^{\circ}, 31^{\circ}-90^{\circ}$ e $91^{\circ}-180^{\circ}$ ciclo.

$\mathrm{O}$ valor médio inicial da microdureza dos corpos de prova submetidos à desinfecção com hipoclorito de sódio a 5,25\% (11,27 \pm 0,41KHN), foi superior e diferiu significativamente dos demais intervalos de avaliação. Ocorreu uma diminuição significativa da microdureza entre a avaliação inicial e o intervalo 1-30 ciclos $(8,28 \pm$ $0,39 \mathrm{KHN}$ ), porém, a partir do intervalo entre o $31^{\circ}-90^{\circ}$ ciclo, ocorreu um aumento significante dos valores médios de microdureza, os quais se mantiveram de forma não significante no intervalo entre o $91^{\circ}-180^{\circ}$ ciclo.

Para a solução G2\%, observou-se valores médios iniciais de microdureza superiores e diferentes significativamente dos demais intervalos de avaliação. A desinfecção com glutaraldeído a $2 \%$ provocou uma redução significativa da microdureza entre a avaliação inicial e o intervalo 1-30 ciclos, e entre este e o intervalo 31-90 ciclos. Os valores médios de microdureza foram semelhantes nos intervalos 31-90 e 91-180 ciclos.

Analisando as comparações entre as soluções estudadas em relação a cada intervalo de avaliação, observou-se que para a avaliação inicial, os corpos de prova submetidos ao armazenamento em água e à desinfecção com hipoclorito de sódio a 1\% (H1\%) apresentaram valores médios de microdureza semelhantes, diferindo das demais soluções. A microdureza dos corpos de prova submetidos às soluções $\mathrm{H} 2 \%, \mathrm{H} 5,25 \% \mathrm{e}$ GC4\% não diferiram significativamente entre si. O mesmo foi observado para as soluções $\mathrm{H} 2 \%$, $\mathrm{H} 5,25 \%$ e G2\%.

No intervalo entre o $1^{\circ}-30^{\circ}$ ciclo de avaliação, somente a solução $\mathrm{H} 5,25 \%$ diferiu significativamente das demais soluções estudadas, com valores médios de microdureza iguais a $(8,28 \pm 0,39 \mathrm{KHN})$. Neste intervalo de avaliação, a resina Tokuyama Rebase II fast exposta à água e às soluções $\mathrm{H} 1 \%, \mathrm{H} 2 \%$, G2\% e GC4\% obteve valores médios de microdureza semelhante.

A avaliação do intervalo 31-90 ciclos apresentou uma semelhança estatística entre os valores médios de microdureza dos corpos de prova submetidos ao armazenamento em água e às soluções $\mathrm{H} 5,25 \%$ e GC4\%. Esta semelhança também foi observada entre as soluções GC4\%, $\mathrm{H} 5,25 \%$ e $\mathrm{H} 2 \%$. O menor valor médio de 
microdureza $(8,57 \pm 0,35 \mathrm{KHN})$ foi encontrado nos corpos de prova submetidos à desinfecção com glutaraldeído a 2\% (G2\%), não diferindo apenas dos valores médios obtidos em $\mathrm{H} 1 \%(8,91 \pm 0,79 \mathrm{KHN})$.

Os valores médios de microdureza dos corpos de prova submetidos às soluções água, G2\% e H1\% foram semelhantes, no intervalo 91-180 ciclos. Nesta avaliação os valores médios de microdureza das soluções desinfetantes experimentais não diferiram significativamente entre si.

\subsubsection{Análise do teste de rugosidade superficial da resina Tokuyama}

\section{Rebase II fast}

A média e desvio-padrão dos valores de rugosidade superficial da resina autopolimerizável (Tokuyama Rebase II fast), para cada um das soluções testadas, nos intervalos de análise inicial, 1-30, 31-90 e 91-180 ciclos estão apresentadas na FIGURA 20.

\section{TOKUYAMA REBASE II FAST - Rugosidade Superficial}

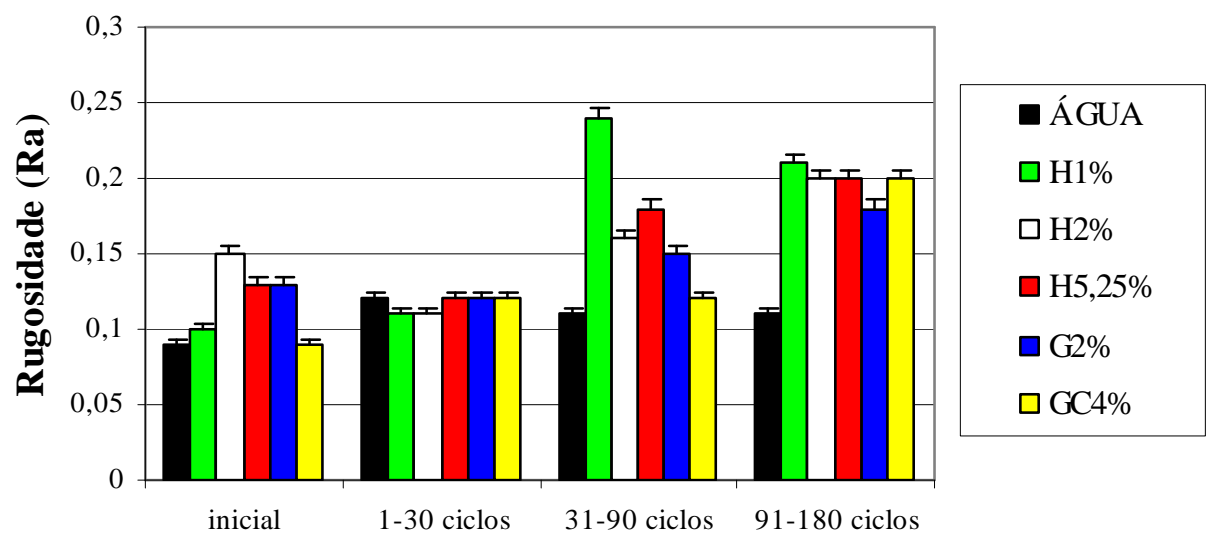

Intervalos de avaliação

FIGURA 20 - Média e desvio padrão dos valores de rugosidade superficial $(\mu \mathrm{m})$ da resina Tokuyama Rebase II fast, para cada solução estudada, nos diferentes intervalos de avaliação.

Para a análise da rugosidade superficial da resina Tokuyama Rebase II fast, a análise de variância indicou a ocorrência de interação significativa entre os fatores soluções e intervalo de avaliação. 
Na TABELA 8 estão apresentados, as médias e desvio padrão dos valores de rugosidade superficial $(\mu \mathrm{m})$, nas diferentes soluções utilizadas e intervalos de avaliação.

TABELA 8 - Teste de Tukey dos valores médios e desvio padrão da rugosidade superficial $(\mu \mathrm{m})$ da resina autopolimerizável Tokuyama Rebase II fast, nas diferentes soluções, em cada intervalo de avaliação.

\begin{tabular}{|c|c|c|c|c|c|}
\hline MATERIAL & SOLUÇÃO & INICIAL & 1-30 CICLOS & 31-90 CICLOS & 91-180 CICLOS \\
\hline $\begin{array}{c}\text { TOKUYAMA } \\
\text { REBASE II } \\
\text { FAST }\end{array}$ & $\begin{array}{c}\text { H } 5,25 \% \\
\text { G } 2 \% \\
\text { GC } 4 \%\end{array}$ & $\begin{array}{c}0,09 \mathrm{aA} \\
\pm \\
0,03 \\
0,10 \mathrm{bA} \\
\pm \\
0,02 \\
0,15 \mathrm{abA} \\
\pm \\
0,05 \\
0,13 \mathrm{aA} \\
\pm \\
0,04 \\
0,13 \mathrm{aA} \\
\pm \\
0,05 \\
0,09 \mathrm{bA} \\
\pm \\
0,04\end{array}$ & $\begin{array}{c}0,12 \mathrm{aA} \\
\pm \\
0,03 \\
0,11 \mathrm{bA} \\
\pm \\
0,03 \\
0,11 \mathrm{bA} \\
\pm \\
0,02 \\
0,12 \mathrm{aA} \\
\pm \\
0,04 \\
0,12 \mathrm{aA} \\
\pm \\
0,03 \\
0,12 \mathrm{abA} \\
\pm \\
0,02\end{array}$ & $\begin{array}{c}0,11 \mathrm{aB} \\
\pm \\
0,01 \\
0,24 \mathrm{aA} \\
\pm \\
0,04 \\
0,16 \mathrm{abAB} \\
\pm \\
0,01 \\
0,18 \mathrm{aAB} \\
\pm \\
0,04 \\
0,15 \mathrm{aAB} \\
\pm \\
0,03 \\
0,12 \mathrm{abB} \\
\pm \\
0,02\end{array}$ & $\begin{array}{c}0,11 \mathrm{aA} \\
\pm \\
0,01 \\
0,21 \mathrm{aA} \\
\pm \\
0,03 \\
0,20 \mathrm{aA} \\
\pm \\
0,02 \\
0,20 \mathrm{aA} \\
\pm \\
0,04 \\
0,18 \mathrm{aA} \\
\pm \\
0,05 \\
0,20 \mathrm{aA} \\
\pm \\
0,02\end{array}$ \\
\hline
\end{tabular}

Médias seguidas por letras minúsculas iguais nas colunas não diferem estatisticamente entre si pelo teste de Tukey. Médias seguidas de letras maiúsculas iguais nas linhas não diferem estatisticamente entre si pelo teste de Tukey.

O efeito da água, sobre a rugosidade superficial da resina Tokuyama Rebase II fast, foi semelhante ao efeito das soluções H5,25\% e G2\%. Nas três soluções, não ocorreram diferenças significativas entre os valores médios iniciais e os demais intervalos de avaliação.

Para a solução $\mathrm{H} 1 \%$, observou-se um aumento não significativo dos valores médios de rugosidade superficial entre a avaliação inicial e o intervalo 1-30 ciclos. Este aumento foi significativo nos intervalos entre o $1^{\circ}-30^{\circ}$ e $31^{\circ}-90^{\circ}$ ciclo, porém, não se manteve significativo no intervalo entre o $91^{\circ}-180^{\circ}$ ciclo.

Os corpos de prova submetidos à desinfecção com hipoclorito de sódio a $2 \%$ (H2\%) apresentaram valores médios iniciais de rugosidade superficial semelhantes aos valores médios encontrados nos intervalos 1-30, 31-90 e 91-180 ciclos. Ocorreram diferenças significativas apenas entre os valores médios de rugosidade dos intervalos 130 e 91-180 ciclos. 
A desinfecção com gluconato de clorexidina a 4\% (GC4\%) provocou um aumento não significativo dos valores médios iniciais de rugosidade superficial, em relação aos intervalos 1-30 e 31-90 ciclos, porém, este aumento foi significativo entre a avaliação inicial e o intervalo 91-180 ciclo. Também não ocorreram diferenças significativas entre os valores médios de rugosidade superficial dos intervalos 1-30, 3190 e $91-180$ ciclos.

Nas comparações entre as soluções utilizadas em cada intervalo de avaliação, a avaliação inicial e os intervalos 1-30 e 91-180 ciclos foram semelhantes entre si, apresentando valores médios entre $0,09 \pm 0,03 \mu \mathrm{m}$ e $0,21 \pm 0,03 \mu \mathrm{m}$. No intervalo entre o $31^{\circ}-90^{\circ}$ ciclo, o maior valor médio de rugosidade superficial $(0,24 \pm$ $0,04 \mu \mathrm{m}$ ) foi encontrado nos corpos de prova submetidos à desinfecção com hipoclorito de sódio a 1\% (H1\%), o qual diferiu significativamente apenas das soluções água e CG4\%. Os valores médios de rugosidade das soluções água, H2\%, H5,25\%, G2\%, GC4\% foram estatisticamente semelhantes. 



\section{Discussão}





\section{Discussão}

O objetivo da imersão de próteses totais em soluções químicas desinfetantes é obter limpeza e descontaminação, através do controle da formação de biofilme sobre a base de resina acrílica, e é desejável que esse processo não cause danos à estrutura química e mecânica desses materiais, tais como alterações na morfologia superficial, resistência flexural e microdureza.

Os estudos encontrados na literatura, os quais avaliavam os efeitos das soluções químicas desinfetantes sobre os materiais utilizados para confecção de dentaduras, são avaliações de curto prazo e não fornecem informações substanciosas a respeito do uso prolongado dessas soluções. Além disso, não há muitos trabalhos avaliando os danos que os desinfetantes podem causar nas propriedades mecânicas das resinas acrílicas, mesmo em avaliações de curto prazo (SHEN; JAVID; COLAIZZI ${ }^{97}$, 1989, ASAD; WATKINSON; HUGGET ${ }^{8}$, 1992, MA; JOHNSON; GORDON ${ }^{62}, 1997$, POLYZOIS; ZISSIS; YANNIKAKIS ${ }^{85}$, 1995, ZISSIS et al. ${ }^{118}, 2000$, PAVARINA et al. ${ }^{81}, 2003$, NEPPELENBROEK et al. ${ }^{74}, 2005$, AZEVEDO et al. $\left.{ }^{10}, 2006\right)$.

\subsection{Microdureza}

Poucos são os estudos sobre a alteração da microdureza de resinas acrílicas após imersão em soluções químicas desinfetantes (SHEN; JAVID; COLAIZZI ${ }^{97}, 1989$, ASAD; WATKINSON; HUGGET ${ }^{8}$, 1992, PAVARINA et al. $^{82}$, 2003, NEPPELENBROEK et al. $^{74}$, 2005, AZEVEDO et al. ${ }^{10}$, 2006) e não foi encontrado nenhum estudo longitudinal que tivesse avaliado esta propriedade nas condições do presente trabalho.

A unidade de medida Knoop, para mensuração de microdureza superficial, é a mais adequada para estudo de materiais poliméricos (WHITMAN et al. ${ }^{112}$, 1987, ABE et al. ${ }^{1}, 1997$, PHILLIPS $^{83}, 2005$, ABE et al. ${ }^{2}, 2001$, SUZUKI $\left.{ }^{99}, 2004\right)$. A indicação da dureza Knoop para os polímeros deve-se ao fato de que a diagonal do losango mensurada para a determinação do valor de dureza, (diagonal de maior comprimento) permanece livre de alterações dimensionais, ao passo que a recuperação elástica e as alterações dimensionais ocorrem ao longo da diagonal mais curta. Portanto, o valor de dureza Knoop virtualmente independe da ductibilidade do material testado devido à ação de rasgamento promovida ao longo da diagonal maior do losango (CRAIG; 
O'BRIEN; POWERS ${ }^{30}, 1988$, O'BRIEN ${ }^{77}, 1997$, DIAZ-ARNOLD; DUNNE; JONES ${ }^{34}$, 1999, PHILLIPS $\left.{ }^{83}, 2005\right)$.

\subsubsection{Resina Termopolimerizável}

Os valores médios de microdureza da resina Lucitone 550, obtidos em cada intervalo de avaliação, estão na TABELA 1, e a análise estatística revelou valores iniciais de microdureza superiores, para todas as soluções testadas, em relação às demais avaliações.

Observou-se uma diminuição significativa dos valores médios de microdureza entre a avaliação inicial e o intervalo 1-30 ciclos, para todas as soluções testadas, e, somente para as soluções água, H1\%, H2\%, H5,25\% e GC4\% os valores de microdureza tornaram-se estáveis após a avaliação do $30^{\circ}$ ciclo.

Comparações entre os resultados de avaliações de curto e longo prazo não são ideais, porém, visto que na literatura especializada não foi encontrado estudo longitudinal semelhante a esse, ou com número de ciclos de imersão próximo ao utilizado no presente trabalho, foi necessário realizar este tipo de comparação.

Os dados deste trabalho estão de acordo com os resultados de NEPPELENBROEK et al. ${ }^{74}, 2005$. Neste estudo, foi avaliada a dureza de duas resinas acrílicas termopolimerizáveis, entre elas, a Lucitone 550, antes e após 4 ciclos de desinfecção, por imersão, durante 10 minutos, em soluções desinfetantes (hipoclorito de sódio a $1 \%$, gluconato de clorexidina a $4 \%$ e perborato de sódio a 3,78\%) e após 15,30 , 60, 90 e 120 dias de imersão em água. Verificou-se uma diminuição significativa dos valores de dureza após as desinfecções, independentemente da solução utilizada. No entanto, este decréscimo foi revertido após 15 dias de armazenamento em água. Os valores de dureza sofreram um aumento contínuo até o $60^{\circ}$ dia de armazenamento em água, e, após este período, não ocorreu aumento significativo da dureza.

Entretanto, estudo de PAVARINA et al. ${ }^{81}$, 2003, não verificou alteração nos valores de microdureza de dentes artificiais após serem imersos, por duas vezes, em hipoclorito de sódio a $1 \%$ e gluconato de clorexidina a $4 \%$, e perborato de sódio a $3,78 \%$ durante 10 minutos. A diminuição da microdureza foi encontrada apenas nos espécimes armazenados em água, por até 120 dias.

No estudo de AZEVEDO et al. ${ }^{10}$, 2006, a microdureza da resina Lucitone 550 também não se alterou de forma significativa após desinfecção com hipoclorito de 
sódio a $1 \%$, gluconato de clorexidina a $4 \%$ e perborato de sódio a $3,78 \%$ durante 10 minutos. Os testes foram realizados em quatro situações: 1 hora após a polimerização; após $48 \mathrm{~h}$ de armazenamento em água destilada; após serem imersos nas soluções desinfetantes, por duas vezes; e após imersão nos desinfetantes por 7 dias. O grupo controle foi testado 1 hora após a polimerização e depois de 7 dias imerso em água, e não apresentou alterações significativas no valor de dureza.

As propriedades físicas das resinas acrílicas, tais como a resistência flexural e a microdureza superficial, estão intimamente relacionadas com a alta quantidade de monômero residual contido na massa da resina. A quantidade de monômero residual nas resinas polimerizáveis depende não só do tipo de polimerização, mas também, da quantidade de monômero na proporção da mistura, do método de processamento, e principalmente, do tempo de polimerização (ARAB; NEWTON; LLOYD ${ }^{5}, 1989$, HARRISON; HUGGETT ${ }^{44}$, 1992, DOGAN et al. ${ }^{36}$, 1995). Diferentes ciclos de polimerização podem resultar em diferentes quantidades de monômero residual; assim, para reduzir essa quantidade e consequientemente, melhorar as propriedades mecânicas das resinas acrílicas, o ciclo de polimerização deve ser de no mínimo 50 minutos (DOGAN et al. $\left.{ }^{36}, 1995\right)$.

Porém, durante a reação de polimerização, quantidades variáveis do monômero (metil-metacrilato) ainda permanecem na resina acrílica (WEAVER; GOEBEL $^{109}$ ，1980, VALLITTU ${ }^{106}$, 1996, KEDJARUNE; CHAROENWORALUK; KOONTONGKAEW $^{51}$, 1999) e atuam como agentes plasticizadores, isto é, promovem flexibilidade e maleabilidade ao material, diminuindo assim, as propriedades mecânicas das resinas polimerizáveis (DOGAN et al. ${ }^{36}$, 1995, LEE; LAY; HSU ${ }^{56}, 2002$, BRAUN et al. $\left.{ }^{18}, 2003\right)$. Este monômero pode continuar a ser consumido por uma polimerização adicional, no local dos radicais livres do polímero, dentro da matriz (LAMB; ELLIS; PRIESTLEY ${ }^{54}$, 1982, KWON; IMAI ${ }^{53}$, 2004) e, além disso, pode ser vagarosamente lixiviado em soluções de armazenamento, aumentando a dureza das resinas acrílicas (BRAUN et al. ${ }^{18}, 2003$ ). Enquanto os monômeros da camada superficial são lixiviados por meios aquosos mais facilmente, os contidos nas camadas mais profundas, podem levar até 5 anos para sofrerem o mesmo processo (SADAMORI; KOTANI; HAMADA $\left.^{93}, 1992\right)$.

Ao mesmo tempo, entretanto, as resinas acrílicas absorvem moléculas de água (DOGAN et al. $^{36}, 1995$, BRADEN $^{17}, 1964$, CUCCI et al. $^{32}, 1998$ ), as quais também agem como plasticizadores, comprometendo a resistência mecânica das resinas 
para base de dentaduras e resinas resilientes (TAKAHASHI; CHAI; KAWAGUCHI ${ }^{100}$, 1998, TAKAHASHI; CHAI; KAWAGUCHI ${ }^{101}$, 1999), por meio de formação de microtrincas decorrentes dos ciclos de absorção e adsorção, além da degradação hidrolítica do polímero, com clivagem de ligações éster, e gradual deterioração de sua infra-estrutura ao longo do tempo (YIU et al. ${ }^{117}, 2004$ ).

A absorção de água pela cadeia polimérica está associada à sua polaridade e à topologia. A polaridade da resina é influenciada pelo número de ligações químicas, do tipo pontes de hidrogênio, e pela atração entre as moléculas do polímero e da água; enquanto a topologia determina a configuração espacial do segmento molecular e a disponibilidade de nanoporos, dentro da estrutura do polímero (YIU et al. ${ }^{117}$, 2004).

Os padrões de difusão são governados pela "teoria de volume livre", na qual a água se difunde através de nanoporos, sem qualquer reação mútua com as moléculas polares do material; ou pela "teoria de interação", na qual a água se difunde através do material aglutinado sucessivamente, em direção aos grupos hidrofílicos. A água absorvida pode se encontrar em duas formas distintas: "livre", a qual ocupa volumes livres entre as cadeias poliméricas e nanoporos, criados durante a polimerização, ou "ligada", a qual está presa à cadeia polimérica por meio de pontes de hidrogênio, com a formação de cápsulas de hidratação primária e secundária, ao redor de terminações hidrofílicas e iônicas da matriz das resinas (YIU et al. ${ }^{117}, 2004$ ).

A diminuição significativa dos valores médios de microdureza entre a avaliação inicial e o intervalo 1-30 ciclos, para todas as soluções testadas, pode ser justificado pela absorção de água e seu efeito plasticizador. Embora só o grupo controle tenha sido armazenado em água, as soluções desinfetantes empregadas neste estudo são aquosas, e provavelmente, foram absorvidas e causaram um amolecimento da camada mais superficial da resina.

Apesar de não ter sido objetivo deste estudo mensurar a quantidade de monômero residual para associar à microdureza, supõe-se que este não tenha efeito sobre as alterações da microdureza superficial da resina Lucitone 550, visto que o ciclo de polimerização atingiu 120 minutos de duração.

A estabilização dos valores médios de microdureza dos corpos de prova submetidos às soluções água, $\mathrm{H} 1 \%, \mathrm{H} 2 \%, \mathrm{H} 5,25 \%$ e GC4\%, após o $30^{\circ}$ ciclo de imersão, pode ser explicada pela saturação do corpo de prova pela umidade. Segundo BRADEN $^{17}$, 1964, a absorção e adsorção de água pelas resinas acrílicas obedecem às leis matemáticas de difusão, regidas pelo coeficiente de difusão (passagem do líquido 
do meio mais saturado, para o meio menos suturado), e equilíbrio de concentração (quando a saturação dos dois meios se equilibra, cessando o transporte do líquido).

A análise da TABELA 1 também revelou, para a solução G2\%, uma diminuição significativa dos valores médios de microdureza entre a avaliação inicial e o intervalo 1-30 ciclos e entre os intervalos 1-30 e 31-90 ciclos, porém, o intervalo 91-180 ciclos apresentou um aumento significativo da microdureza em relação ao intervalo 3190 ciclos.

Poucos estudos foram encontrados, na literatura especializada, sobre a ação do glutaraldeído sobre as resinas acrílicas (POLYZOIS; ZISSIS; YANNIKAKIS ${ }^{85}$, 1995, SHEN; JAVID; COLAIZZI ${ }^{97}$, 1989, ASAD; WATKINSON; HUGGET ${ }^{8}, 1992$, ASAD; WATKINSON; HUGGET ${ }^{9}$, 1993), e nenhum destes apresentou uma avaliação longitudinal.

Alguns trabalhos avaliaram as alterações de microdureza e flexurais, de resinas termopolimerizáveis, após desinfecção com glutaraldeído a $2 \%$, em períodos que variavam de 1 hora a 7 dias de imersão (POLYZOIS; ZISSIS; YANNIKAKIS ${ }^{85}$, 1995, ASAD; WATKINSON; HUGGET ${ }^{8}$, 1992, ASAD; WATKINSON; HUGGET ${ }^{9}, 1993$ ). Em 7 dias de imersão, não foram observadas alterações significativas nas propriedades flexurais (POLYZOIS; ZISSIS; YANNIKAKIS ${ }^{85}$, 1995, ASAD; WATKINSON; HUGGET $^{8}$, 1992), e ocorreu uma redução significativa da microdureza, indicando que o efeito do desinfetante se restringe apenas às camadas superficiais da resina (ASAD; WATKINSON; HUGGET $^{9}$, 1993), porém, os autores confirmam a necessidade de estudos longitudinais a fim de corroborar estes resultados.

Provavelmente, os valores de microdureza dos corpos de prova submetidos à desinfecção com glutaraldeído a 2\% reduziram em virtude da absorção de líquido e de seu efeito plasticizador. A retomada do aumento da microdureza, após o $90^{\circ}$ ciclo deimersão, pode ser explicada, possivelmente, pela reação do glutaraldeído com os polímeros da resina, modificando a estrutura das cadeias poliméricas.

$\mathrm{Na}$ comparação entre as soluções estudadas, em cada um dos intervalos de avaliação, observou-se que, na avaliação inicial, os valores médios de microdureza Knoop variaram entre 20,61 \pm 1,36KHN (GC4\%) e 17,02 \pm 0,83KHN (H5,25\%). Embora a dureza Knoop seja mais indicada para materiais poliméricos, a maioria dos estudos encontrados apresenta valores de dureza Vickers (ASAD; WATKINSON; HUGGET, 1993 ${ }^{9}$, PAVARINA et al. ${ }^{81}$, 2003, NEPPELENBROEK et al. ${ }^{74}, 2005$, AZEVEDO et al. ${ }^{10}$, 2006), o que dificulta comparações. Os valores de dureza Knoop 
encontrados em estudo de BRAUN et al. ${ }^{18}$, 2003, para avaliação de uma resina termopolimerizável, estão de acordo com os valores iniciais de microdureza do presente trabalho.

A variação dos valores de microdureza, entre os intervalos de avaliação do presente estudo, foi comparada aos outros trabalhos da literatura, pois, não foi considerada a unidade de medida adotada, mas sim, a variação dos valores no decorrer das pesquisas.

No intervalo entre o $91^{\circ}-180^{\circ}$ ciclo de avaliação, o maior valor de microdureza foi encontrado nos corpos de prova submetidos à desinfecção com glutaraldeído a $2 \%$ (G2\%), provavelmente devido a alguma modificação na cadeia polimérica, após as imersões repetitivas neste desinfetante. Os corpos de prova submetidos às demais soluções desinfetantes e à água obtiveram valores semelhantes de microdureza, demonstrando que o hipoclorito de sódio e o gluconato de clorexidina também podem agir como agentes plasticizadores.

\subsubsection{Resinas Autopolimerizáveis}

Os valores médios de microdureza das resinas autopolimerizáveis Jet, Kooliner e Tokuyama Rebase II fast estão dispostos nas TABELAS 3, 5 e 7, respectivamente.

A análise destes dados demonstra que a imersão em água causou uma diminuição dos valores médios de microdureza dos três materiais autopolimerizáveis, entre a avaliação inicial e o intervalo 1-30 ciclos. Com exceção da resina Tokuyama Reabase II fast, os valores de microdureza se estabilizaram após o $30^{\circ}$ ciclo.

Alguns estudos avaliaram o efeito da absorção de água sobre a dureza de resinas acrílicas autopolimerizáveis, em períodos de armazenamento variando entre 24 horas, 7, 14, 32, 60 e 120 dias, e comprovaram um aumento dos valores de dureza, após 7 dias (DIAZ-ARNOLD; DUNNE; JONES ${ }^{34}$, 1999, AZEVEDO et al. ${ }^{10}, 2006$ ), 32 dias (BRAUN et al. ${ }^{18}$, 2003) e 60 dias de imersão em água (NEPPELENBROEK et al. ${ }^{74}$, 2005), justificado por uma possível polimerização adicional desses materiais, a qual teria superado o efeito plasticizante da água.

As resinas autopolimerizáveis têm altos níveis de monômeros residuais quando comparado às resinas termo e fotoativadas. Os valores de microdureza das resinas autopolimerizáveis são inferiores em relação às termopolimerizáveis, pois a 
polimerização em temperatura ambiente associada à presença de oxigênio, inibe ou retarda a polimerização, gerando grandes quantidades de monômero residual e espaços vazios entre as cadeias poliméricas. Portanto, quando imersas em água, as resinas autopolimerizáveis liberam maior quantidade de monômero residual, e absorvem mais umidade, promovendo a plasticização das camadas superficiais (DOGAN et al. ${ }^{36}, 1995$, LIN et al. ${ }^{57}$, 2000, LEE, LAI, HSU $\left.{ }^{56}, 2002\right)$.

O resultado do presente trabalho corrobora a hipótese de que a água se difunde pela resina até que esta atinja a saturação, e causa um amolecimento das camadas mais superficiais, diminuindo os valores de microdureza. Não foi observado qualquer aumento dos valores de microdureza, após a imersão prolongada em água, portanto, provavelmente, nas condições experimentais empregadas, não aconteceu polimerização adicional dos materiais, ao longo do estudo.

A resina Tokuyama Reabase II fast apresentou uma diminuição significativa dos valores de microdureza nos intervalos entre o $31^{\circ}-90^{\circ}$ e $91^{\circ}-180^{\circ}$ ciclo de avaliação. Este evento pode ter ocorrido devido a absorção de água pelo material, que provavelmente, não atingiu a saturação no mesmo momento dos outros materiais avaliados, causando assim, uma diminuição progressiva dos valores de microdureza. Dessa forma, é possível que a resina Tokuyama Rebase II fast possua maior quantidade de nanoespaços entre as cadeias poliméricas, ou que seja mais hidrofóbica, dificultando a difusão da água em seu interior, sendo necessário um tempo maior de armazenamento para que a água se difunda pelo corpo de prova, até atingir a saturação.

As soluções desinfetantes $\mathrm{H} 1 \%, \mathrm{H} 2 \%, \mathrm{H} 5,25 \%$ e $\mathrm{GC} 4 \%$ tiveram efeito semelhante nas resinas autopolimerizáveis Jet e Tokuyama Rebase II fast (TABELA 3 e TABELA 7). Os resultados mostram uma diminuição significativa dos valores médios iniciais, em comparação aos demais intervalos de avaliação. Este achado sugere que estas soluções, assim como a água, são absorvidas pela resina e podem agir como plasticizadores, alterando sua microdureza superficial, quando os ciclos de desinfecção são repetidos várias vezes.

Somente a solução $\mathrm{H} 5,25 \%$ causou um aumento significativo dos valores médios de microdureza das resinas Jet e Tokuyama Rebase II fast, após o $30^{\circ}$ ciclo de avaliação. Sabe-se que a estabilidade das soluções preparadas com hipoclorito de sódio é afetada por compostos orgânicos, metais pesados, íons, diluição, tempo, luz e temperatura. Na presença desses elementos, o hipoclorito de sódio se dissocia, liberando 
íons cloro; e esta dissociação é maior em altas concentrações (GERHARDT; WILLIAMS $\left.^{40}, 1991\right)$.

É possível que tenha ocorrido a absorção de hipoclorito de sódio pelos materiais, uma vez que os valores de microdureza diminuíram em um primeiro momento; e é possível também, que o hipoclorito de sódio, em sua maior concentração $(5,25 \%)$, tenha liberado quantidades maiores de íons cloro, os quais poderiam estar alterando a composição química das resinas, e conseqüentemente, aumentando os valores de microdureza.

As desinfecções com glutaraldeído a $2 \%$ causaram, nas resinas Jet e Tokuyama Rebase II fast, uma diminuição significativa dos valores médios iniciais de microdureza em relação ao intervalo 1-30 ciclos. Porém, esta diminuição foi significativa entre os intervalos 1-30 e 31-90 ciclos, somente para a resina Tokuyama Rebase II fast.

O glutaraldeído, assim, como as outras soluções, pode ter sido absorvido pelas resinas autopolimerizáveis, e ter agido como plasticizador, diminuindo a microdureza. É provável que esta solução tenha reagido com a estrutura química da resina Tokuyama Rebase II fast, provocando a diminuição da microdureza entre os intervalos 1-30 e 31-90 ciclos.

A resina Kooliner apresentou valores iniciais de microdureza superiores às demais avaliações, para todas as soluções desinfetantes testadas, indicando que estas soluções, provavelmente, foram absorvidas e agiram como plasticizadores (TABELA $5)$.

A diminuição significativa da microdureza dos corpos de prova da resina Kooliner, submetidos às soluções H1\% e H2\%, entre os intervalos 1-30 e 31-90 ciclos, pode ser atribuída a uma maior absorção dessas soluções por este material. A resina Kooliner não possui, em sua composição, agentes de ligação cruzada, os quais garantem melhores propriedades mecânicas, e segundo ARIMA; MURATA; HAMADA ${ }^{6}$, 1996, a ausência destes agentes promove maior absorção de água.

As desinfecções da resina Kooliner, com gluconato de clorexidina a 4\%, provocaram uma redução dos valores médios de microdureza entre a avaliação inicial e o intervalo 1-30 ciclos e esta diminuição também foi significativa entre os intervalos 3190 e 91-180 ciclos. Esta redução pode ser atribuída à possível absorção da solução desinfetante pelo corpo de prova, causando um amolecimento das camadas mais 
superficiais, ou até mesmo pela alta concentração da solução (NEPPELENBROEK et al. $\left.^{74}, 2005\right)$.

As análises da microdureza em cada intervalo de avaliação, de acordo com a solução desinfetante utilizada, estão dispostas nas TABELAS 3, 5 e 7. Os valores iniciais de microdureza Knoop da resina Jet não diferiram significativamente entre si, e estão de acordo com os achados de BRAUN et al. ${ }^{18}$, 2003. As resinas Kooliner e Tokuyama Rebase II fast apresentaram variação de valores médios de microdureza entre $14,09 \pm 1,63$ e 11,56 $\pm 1,11$, respectivamente, que pode ser atribuída à técnica de manipulação desses materiais.

No intervalo entre o $1^{\circ}-30^{\circ}$ ciclo, somente o hipoclorito de sódio a $5,25 \%$ foi capaz de causar alterações na microdureza dos corpos de prova da resina Tokuyama Rebase II fast. Possivelmente, sua alta concentração favoreceu uma maior liberação de íons cloro, os quais podem ter causado alterações na composição química deste material mais rapidamente, em relação às outras resinas autopolimerizáveis estudadas.

$1,63 \square 1,11 \square$ A semelhança entre o efeito da água e dos desinfetantes sobre a

A semelhança entre o efeito da água e dos desinfetantes sobre a microdureza da resina Jet, no intervalo entre o $31^{\circ}-90^{\circ}$ ciclo, não foi observada nos corpos de prova das resinas Kooliner e Tokuyama Rebase II fast. Nestes materiais, os corpos de prova armazenados em água apresentaram valores de microdureza superiores às soluções desinfetantes, sugerindo que estas soluções podem agir como plasticizadores mais efetivos do que a água.

A avaliação do intervalo entre o $91^{\circ}-180^{\circ}$ ciclo constatou que o efeito das soluções desinfetantes estudadas foi semelhante, independente do tipo de solução. Este achado corrobora a hipótese de que as soluções desinfetantes aquosas são absorvidas e agem como plasticizadores, e ainda sugere a possibilidade de alteração da estrutura química dessas resinas, em nível das cadeias poliméricas, quando expostas aos desinfetantes, em longo prazo, causando a redução da microdureza.

\subsection{Rugosidade superficial}

Sabe-se que a rugosidade das superfícies intra-orais é responsável pela retenção de biofilme microbiano (BOLLEN; LAMBRECHTS; QUIRYNEN ${ }^{15}$, 1997). A superfície rugosa proporciona proteção aos microorganismos, uma vez que dificulta que 
sofram a ação de forças de cisalhamento; além disso, promove uma maior área para seu acúmulo, favorecendo assim, o desenvolvimento de biofilme maduro (BOLLEN; LAMBRECHTS; QUIRYNEN ${ }^{15}$, 1997, RADFORD; CHALLACOMBE; WALTER ${ }^{88}$, 1999, TEUGHELS et al. $\left.{ }^{102}, 2006\right)$.

O parâmetro mais utilizado para mensuração de rugosidade superficial é a média de rugosidade $\mathrm{Ra}$, a qual é representada pela variação aritmética média entre as irregularidades (reentrâncias e saliências) de um trajeto de mensuração, sobre a superfície (RADFORD; CHALLACOMBE; WALTER $\left.{ }^{88}, 1999\right)$ ).

Os resultados de estudos sobre o valor da rugosidade de resinas acrílicas, tanto para resinas acrílicas termopolimerizáveis, quanto para as autopolimerizáveis, não são claros, pois dependem do tipo de polimento superficial (BOLLEN; LAMBRECHTS; QUIRYNEN, ${ }^{15}$ 1997). Entretanto, alguns autores consideram que valores médios de $\mathrm{Ra}$ iguais ou inferiores a $0,2 \mu \mathrm{m}$ dificultam a adesão de microorganismos sobre as superfícies (BOLLEN; LAMBRECHTS; QUIRYNEN ${ }^{15}$, 1997, TEUGHELS et al. $\left.{ }^{102}, 2006\right)$

As próteses totais são consideradas verdadeiros reservatórios de microorganismos, uma vez que as técnicas de polimento convencionais, dificilmente, atingem níveis de rugosidade superficial próximos ou inferiores a $0,2 \mu \mathrm{m}$ (VERRAN; MARYAN $^{107}$, 1997); portanto, o uso de soluções desinfetantes para controle de biofilme microbiano e manutenção da saúde bucal é inquestionável.

A literatura especializada apresenta poucos estudos avaliando as alterações de rugosidade superficial, de resinas acrílicas, promovidas por uso de soluções químicas desinfetantes (SHEN; JAVID; COLAIZZI ${ }^{97}$, 1989, MA; JOHNSON; GORDON ${ }^{62}$, 1997, AZEVEDO et al., 2006 ${ }^{10}$ ), ademais, nenhuma informação foi encontrada a respeito do efeito dessas soluções, sobre os materiais de base de dentaduras, em longo prazo. Assim, embora não seja ideal comparar os resultados da literatura com os do presente estudo, na ausência de estudos longitudinais, tais comparações foram realizadas.

\subsubsection{Resina Termopolimerizável}

Os valores médios iniciais de rugosidade superficial da resina Lucitone 550 variaram entre $0,08 \pm 0,02 \mu \mathrm{m}$ e $0,06 \pm 0,02 \mu \mathrm{m}$ (TABELA 2), e estão próximos aos valores obtidos por MA; JOHNSON; GORDON ${ }^{62}$, 1997. Estudos de HARRISON; 
JOHNSON; DOUGLAS ${ }^{45}, 2004$ e AZEVEDO et al. ${ }^{10}$, 2006 obtiveram valores mais elevados, provavelmente, por terem utilizado técnica de polimento diferente do presente trabalho.

Somente os corpos de prova submetidos ao armazenamento em água não sofreram alterações nos valores de rugosidade superficial, ao longo do intervalo de avaliação adotado. Os espécimes submetidos à desinfecção com as soluções H1\%, H2\% e $\mathrm{H} 5,25 \%$ apresentaram aumento significativo dos valores médios de rugosidade superficial nos intervalos entre o $31^{\circ}-90^{\circ}$ ciclo, enquanto os expostos às soluções $\mathrm{G} 2 \%$ e GC4\%, apresentaram aumento da rugosidade superficial no intervalo entre o $91^{\circ}-180^{\circ}$ ciclo. A solução $\mathrm{H} 2 \%$ causou um aumento da rugosidade superficial também no intervalo entre o $91^{\circ}-180^{\circ}$ ciclo.

Os trabalhos encontrados na literatura não verificaram alterações significativas nos valores de rugosidade superficial de resinas termopolimerizáveis após 7 dias de imersão em soluções de hipoclorito de sódio a 5,25\%, glutaraldeído a $2 \%$ (MA; JOHNSON; GORDON ${ }^{62}$, 1997), hipoclorito de sódio a $1 \%$ e gluconato de clorexidina a 4\% (AZEVEDO et al. ${ }^{10}$, 2006). Porém, SHEN; JAVID; COLAIZZI ${ }^{97}$, 1989, constataram, por meio de um microscópio óptico, alterações morfológicas superficiais qualitativas nos espécimes de resina Lucitone 550, após imersões que variaram de 12 horas a 3 semanas, em glutaraldeído a $2 \%$.

Especula-se que a imersão de resinas acrílicas termopolimerizáveis polidas quimicamente, em soluções desinfetantes como hipoclorito de sódio e glutaraldeído, pode promover a dissolução da película superficial de polimento, interferindo na rugosidade superficial e favorecendo a difusão dessas soluções no interior da massa da resina (ORSI; ANDRADE $\left.{ }^{79}, 2004\right)$.

No presente estudo, possivelmente, as soluções desinfetantes utilizadas promoveram a dissolução da camada mais externa de polimento, expondo as camadas subjacentes, as quais foram polidas com lixas de maior granulação, aumentando assim, os valores de rugosidade superficial. Embora não tenha sido objetivo deste trabalho avaliar o polimento das resinas especificamente, no decorrer do estudo, foi observado, por meio de análise visual dos espécimes, a perda do brilho promovido pelo polimento. De forma geral, os corpos de prova tornaram-se mais opacos e com sua superfície mais riscada, após as desinfecções.

A redução significativa dos valores médios de rugosidade superficial, no intervalo entre o $91^{\circ}-180^{\circ}$ ciclo, encontrada nos espécimes submetidos à desinfecção 
com $\mathrm{H} 5,25 \%$ pode ser explicada pela extensão da superfície analisada. Os corpos de prova apresentavam uma grande superfície para a realização dos testes, e estes foram realizados repetidamente, em locais aleatórios, de forma que poderiam acontecer diferenças entre as leituras.

Na comparação entre as diferentes soluções, em cada intervalo de avaliação (TABELA 2), apenas nos intervalos entre o $31^{\circ}-90^{\circ}$ e $91^{\circ}-180^{\circ}$ ciclo, as soluções diferiram entre si. No intervalo entre o $31^{\circ}-90^{\circ}$ ciclo, os espécimes submetidos às soluções $\mathrm{H} 1 \%$ e $\mathrm{H} 5,25 \%$ apresentaram os maiores valores médios de rugosidade superficial, não diferindo entre si, enquanto os submetidos à G2\% e GC4\% não diferiram daqueles imersos em água, os quais apresentaram menor valor médio de rugosidade superficial. Porém, no intervalo entre o $91^{\circ}-180^{\circ}$ ciclo, os maiores valores médios foram encontrados nos espécimes expostos a $\mathrm{H} 1 \%, \mathrm{H} 2 \%$ e GC4\%.

O efeito das soluções desinfetantes sobre a rugosidade superficial da resina termopolimerizável pode estar associado à alta concentração do produto, bem como ao tempo de imersão. As soluções de $\mathrm{H} 1 \%$ e $\mathrm{H} 5,25 \%$, no intervalo entre o $31^{\circ}-90^{\circ}$ ciclo, tiveram efeito semelhante sobre a alteração de rugosidade, indicando que, neste período, menores concentrações utilizadas por maior tempo são tão prejudiciais ao polimento da resina Lucitone 550 quanto altas concentrações utilizadas em menor tempo.

Apesar das soluções desinfetantes utilizadas neste experimento causarem aumento dos valores médios de rugosidade superficial, o valor de Ra encontrado intervalo entre o $91^{\circ}-180^{\circ}$ ciclo ainda se encontra muito próximo ao limiar de rugosidade descrito por BOLLEN; LAMBRECHTS; QUIRYNEN ${ }^{15}$, 1997, e TEUGHELS et al. ${ }^{102}, 2006$.

\subsubsection{Resinas Autopolimerizáveis}

Na TABELA 4 e 8, estão dispostos os resultados dos testes de rugosidade superficial das resinas autopolimerizáveis Jet e Tokuyama, respectivamente.

A imersão em água causou, na resina Jet, aumento significativo da rugosidade superficial somente entre a avaliação inicial e o intervalo 1-30 ciclos. Visto que este resultado não foi observado nos outros materiais testados (TABELA 6 e 8), pode-se supor que a extensão da superfície avaliada e a localização aleatória da mensuração da rugosidade podem ser responsáveis pelo resultado obtido. 
A resina Jet foi mais sensível em relação à Tokuyama Rebase II fast, quando submetida às soluções desinfetantes. As soluções H1\% e H2\% causaram, na resina Jet, um aumento significativo dos valores de rugosidade superficial, em menor tempo (1-30 ciclos), porém, na resina Tokuyama Rebase II fast, este aumento ocorreu mais tardiamente (a partir do $30^{\circ}$ ciclo). As soluções $\mathrm{H} 5,25 \%$ e $\mathrm{G} 2 \%$ tiveram efeito significativo sobre a rugosidade, somente na resina Jet. O gluconato de clorexidina a $4 \%$, por sua vez, apresentou aumento significativo entre a avaliação inicial e intervalo 31-90 ciclos, para a resina Jet e entre a avaliação inicial e o intervalo 91-180 ciclos, para a resina Tokuyama Rebase II fast.

Não ocorreu interação entre as variáveis intervalos de avaliação e soluções, para a resina Kooliner, a qual apresentou valor médio de rugosidade superficial superior a $0,2 \mu \mathrm{m}$. Resultado semelhante foi encontrado em estudo de SHEN; JAVID; COLAIZZI $^{97}$, 1989, MA; JOHNSON; GORDON ${ }^{62}$, 1997, AZEVEDO et al. ${ }^{10}, 2006$. Possivelmente as soluções utilizadas não foram capazes de remover o polimento superficial dessa resina, causando alterações nos valores de rugosidade superficial, em 180 ciclos de imersão.

Na comparação entre as soluções, em cada tempo de avaliação, observou-se, para a resina Jet, diferenças significativas entre as soluções empregadas, somente nos intervalos 31-90 e 91-180 ciclos. No intervalo 31-90 ciclos, o maior valor de rugosidade foi encontrado nos corpos de prova submetidos à desinfecção com H1\% $(0,24 \pm 0,03 \mu \mathrm{m})$, o qual diferiu significativamente das demais soluções, sugerindo que neste tempo de avaliação, a solução de hipoclorito de sódio em menor concentração, mas utilizada em imersões mais prolongadas, causa mais danos quando comparada às concentrações mais elevadas, utilizadas em menor tempo.

A literatura especializada não esclarece as consequiências da ação prolongada de soluções de hipoclorito de sódio sobre a superfície de resinas acrílicas, porém, Mc GOWAN; SHIMODA; WOOLSEY ${ }^{65}$, 1988, testaram, qualitativamente, o efeito da desinfecção com hipoclorito de sódio sobre a alteração morfológica superficial de metais utilizados para a confecção de armações metálicas de próteses parciais removíveis. No metal, o tempo de exposição às soluções de hipoclorito de sódio é determinante para causar corrosão. Mesmo as soluções mais concentradas $(5,25 \%)$ podem ser utilizadas, em menor tempo de imersão (3 a 5 minutos), sem causar danos à estrutura metálica. 
Assim como no metal, a imersão dos espécimes do presente estudo, na solução $\mathrm{H} 1 \%$ pode ter acusado uma degradação superficial, similar à corrosão dos metais, a qual foi detectada no intervalo entre o $31^{\circ}-90^{\circ}$ ciclo.

Ainda no $90^{\circ}$ ciclo, observa-se que o efeito de G2\% e GC4\% sobre a rugosidade da resina Jet foi semelhante ao efeito da água, indicando que estes desinfetantes causaram menores alterações de rugosidade superficial, em relação aos desinfetantes a base de hipoclorito de sódio (TABELA 4).

No intervalo entre o $91^{\circ}-180^{\circ}$ ciclo, os corpos de prova da resina Jet imersos em todas as soluções desinfetantes, com exceção da água, apresentaram valores médios de rugosidade superficial muito próximos, e a solução GC4\% diferiu estatisticamente somente de G2\% (TABELA 4). Não ocorreram diferenças significativas entre as soluções a base de hipoclorito de sódio, indicando que, ao final do experimento, o número de ciclos de desinfecção determinou as alterações de rugosidade, não importando a concentração utilizada.

Para a resina Tokuyama Rebase II fast, no intervalo entre o $31^{\circ}-90^{\circ}$ ciclo, a maior média de rugosidade foi encontrada nos espécimes desinfetados com $\mathrm{H} 1 \%$ $(0,24 \pm 0,04 \mu \mathrm{m})$, diferindo somente das soluções água e GC4\%. Possivelmente, em 90 ciclos de imersão, o gluconato de clorexidina não foi capaz de deteriorar a superfície deste material. No intervalo entre o $91^{\circ}-180^{\circ}$ ciclo, os corpos de apresentaram valores semelhantes de rugosidade, independente da solução desinfetante utilizada, indicando que, em longo prazo, todas as soluções testadas causam aumento da rugosidade superficial (TABELA 8).

Diante da ausência de informações na literatura especializada, houve dificuldade em discutir alguns resultados do presente estudo. Portanto, é essencial realizar trabalhos futuros, juntamente com profissionais da área química, com ênfase na análise estrutural das resinas acrílicas, após imersão em soluções desinfetantes. Um estudo das alterações estruturais poderá responder e justificar, com precisão, os questionamentos que ainda permanecem sem resposta. 
6. Conclusões 



\section{Conclusões}

As seguintes conclusões foram obtidas a partir deste trabalho:

\subsection{Microdureza}

1) A água e as soluções desinfetantes causaram a diminuição significativa da microdureza da resina termopolimerizável Lucitone 550 no primeiro intervalo de avaliação (1-30 ciclos de imersão). Após este período, a única solução que apresentou oscilação da microdureza foi G2\%, que causou uma diminuição significativa da microdureza em 90 ciclos, e aumento significativo após este período. As soluções H5,25\% e G2\% diferiram entre si nos intervalos 1-30 e 91-180 ciclos.

2) Ao final de 180 ciclos de imersão em água, a resina autopolimerizável Jet apresentou menor valor de microdureza em relação às soluções desinfetantes. Todos os desinfetantes causaram diminuição significativa da microdureza da resina Jet em 180 ciclos de imersão, exceto as soluções H5,25\% e G2\%, que causaram uma diminuição da microdureza inicialmente, a qual voltou a aumentar significativamente após 30 ciclos de imersão.

3) As soluções água, $\mathrm{H} 5,25 \%, \mathrm{G} 2 \%$ e GC4\% causaram uma redução significativa da microdureza da resina autopolimerizável Kooliner, seguida por uma estabilização desses valores após 30 ciclos de imersão, com exceção de GC4\%, que apresentou redução de dureza após 90 ciclos. As soluções $\mathrm{H} 1 \%, \mathrm{H} 2 \%$ e GC4\% causaram uma redução contínua da microdureza em até 90 ciclos de imersão, seguida por uma estabilização desses valores após este período. O comportamento das soluções desinfetantes sobre a microdureza foi semelhante em todos os intervalos de avaliação. 
4) A água e as soluções desinfetantes causaram, na resina autopolimerizável Tokuyama Rebase II fast, uma redução significativa da microdureza em 30 ciclos de imersão e após este período, as soluções $\mathrm{H} 1 \%$, H2\% e GC4\% não provocaram alterações. A solução $\mathrm{H} 5,25 \%$ causou uma diminuição significativa de microdureza inicialmente (1-30 ciclos), a qual foi revertida na avaliação seguinte (31-90 ciclos), enquanto a solução G2\% causou uma redução contínua significativa da microdureza em 90 ciclos, a qual foi mantida na avaliação seguinte (91180 ciclos). Ao final de experimento (180 ciclos), todos os desinfetantes comportaram-se de forma semelhante, em relação às alterações de microdureza.

5) Embora a solução $\mathrm{H} 5,25 \%$ tenha sido semelhante a $\mathrm{H} 2 \%$ e causado maior alteração na microdureza da resina Lucitone 550, ao final do experimento (180 ciclos), não ocorreu diferença significante entre os desinfetantes para as resinas autopolimerizáveis.

\subsection{Rugosidade Superficial}

1) Todas as soluções desinfetantes causaram aumento significativo dos valores de rugosidade superficial da resina Lucitone 550, em 180 ciclos de desinfecção enquanto as soluções a base de hipoclorito de sódio causaram danos em menor tempo (31-90 ciclos). As soluções G2\% e GC4\% podem ser utilizadas para desinfecções diárias, por até 90 ciclos, sem provocar alterações significativas de rugosidade superficial.

2) A água e as soluções desinfetantes testadas causaram aumento significativo da rugosidade superficial da resina autopolimerizável Jet, ao final de 180 ciclos de imersão, sendo que, para as soluções $\mathrm{H} 1 \%$ e $\mathrm{H} 2 \%$, um maior aumento de rugosidade foi atingido com um menor número de ciclos (1-30 ciclos). A partir do $30^{\circ}$ ciclo, todos os desinfetantes causaram alterações de rugosidade superficial na resina Jet. 
3) Não ocorreu interação significativa para os fatores soluções e intervalos de avaliação, para análise de rugosidade superficial da resina autopolimerizável Kooliner.

4) As soluções água, $\mathrm{H} 5,25 \%, \mathrm{H} 2 \%$ e G2\% não causaram alterações significativas na rugosidade superficial superficial da resina autopolimerizável Tokuyama Rebase II fast. A solução H1\% alterou a rugosidade superficial a partir do $30^{\circ}$ ciclo, enquanto a solução GC4\% alterou a partir do $90^{\circ}$ ciclo.

5) Ao final do experimento (180 ciclos), as soluções $\mathrm{H} 1 \%$, H2\% e GC4\% causaram maior alteração na rugosidade superficial da resina Lucitone 550. Estas mesmas soluções, além de $\mathrm{H} 5,25 \%$, promoveram maior rugosidade na resina Jet, enquanto que, para a resina Tokuyama Rebase II fast, não houve diferença entre os desinfetantes. 



\section{Referências}

Bibliográficas 



\section{Referências Bibliográficas}

1. Abe Y, Sato Y, Akagawa Y, Ohkawa S. An in vitro study of high-strength resin posterior denture tooth wear. Int J Prosthodont. 1997; 10(1):28-34.

2. Abe Y, Sato Y, Taji T, Akagawa Y, Lambrechts P, Vanherle G. An in vitro wear study of posterior denture tooth materials on human enamel. J Oral Rehabil. 2001; 28(5):407-12.

3. Abelson DC. Denture plaque and denture cleansers: review of the literature. Gerodontics. 1985; 1(5):202-6.

4. American Dental Association. Infection control recomendations for the dental office and dental laboratory. J Am Dent Assoc. Chicago 1992; suppl:1-8.

5. Arab J, Newton JP, Lloyd CH. The effect of an elevated level of residual monomer on the whitening of a denture base and its physical properties. J Dent. 1989; 17(4):189-94.

6. Arima T, Murata $\mathrm{H}$, Hamada $\mathrm{T}$. The effects of cross-linking agents on the water sorption and solubility characteristics of denture base resin. J Oral Rehabil. 1996; 23(7):476-80.

7. Arkell S, Shinnick A. Update on oral candidosis. Nurs Times. 2003; 99(48):52-3.

8. Asad T, Watkinson AC, Huggett R. The effect of disinfection procedures on flexural properties of denture base acrylic resins. J Prosthet Dent. 1992; 68(1):191-5.

9. Asad T, Watkinson AC, Huggett R. The effects of various disinfectant solutions on the surface hardness of an acrylic resin denture base material. Int J Prosthodont. 1993; 6(1):9-12.

10. Azevedo A, Machado AL, Vergani CE, Giampaolo ET, Pavarina AC, Magnani R. Effect of disinfectants on the hardness and roughness of reline acrylic resins. J Prosthodont. 2006; 15(4):235-42. 
11. Barbeau J, Seguin J, Goulet JP, de Koninck L, Avon SL, Lalonde B, et al. Reassessing the presence of Candida albicans in denture-related stomatitis. Oral Surg Oral Med Oral Pathol Oral Radiol Endod. 2003; 95(1):51-9.

12. Basson NJ, Quick AN, Thomas CJ. Household products as sanitising agents in denture cleansing. J Dent Assoc S Afr. 1992; 47(10):437-9.

13. Bell JA, Brockmann SL, Feil P, Sackuvich DA. The effectiveness of two disinfectants on denture base acrylic resin with an organic load. J Prosthet Dent. 1989; 61(5):580-3.

14. Block SS. Disinfection, sterilization, and preservation 4ed. Philadelphia: Lea \& Febiger; 1991.1162.

15. Bollen CM, Lambrechts P, Quirynen M. Comparison of surface roughness of oral hard materials to the threshold surface roughness for bacterial plaque retention: a review of the literature. Dent Mater. 1997; 13(4):258-69.

16. Brace ML, Plummer KD. Practical denture disinfection. J Prosthet Dent. 1993; 70(6):538-40.

17. Braden M. The absorption of water by acrylic resins ando other materials. J Prosthet Dent. 1964; 14:307-316.

18. Braun KO, Mello JA, Rached RN, Del Bel Cury AA. Surface texture and some properties of acrylic resins submitted to chemical polishing. J Oral Rehabil. 2003; 30(1):91-8.

19. Budtz-Jorgensen E. Materials and methods for cleaning dentures. J Prosthet Dent. 1979; 42(6):619-23.

20. Budtz-Jorgensen E, Theilade E. Regional variations in viable bacterial and yeast counts of 1-week-old denture plaque in denture-induced stomatitis. Scand J Dent Res. 1983; 91(4):288-95.

21. Budtz-Jorgensen E, Theilade E, Theilade J, Zander HA. Method for studying the development, structure and microflora of denture plaque. Scand J Dent Res. 1981; 89(2):149-56. 
22. Catalan A, Herrera R, Martinez A. Denture plaque and palatal mucosa in denture stomatitis: scanning electron microscopic and microbiologic study. J Prosthet Dent. $1987 ; 57(5): 581-6$.

23. Chan EC, Iugovaz I, Siboo R, Bilyk M, Barolet R, Amsel R, et al. Comparison of two popular methods for removal and killing of bacteria from dentures. J Can Dent Assoc. 1991; 57(12):937-9.

24. Chandra J, Mukherjee PK, Leidich SD, Faddoul FF, Hoyer LL, Douglas LJ, et al. Antifungal resistance of candidal biofilms formed on denture acrylic in vitro. J Dent Res. 2001; 80(3):903-8.

25. Chau VB, Saunders TR, Pimsler M, Elfring DR. In-depth disinfection of acrylic resins. J Prosthet Dent. 1995; 74(3):309-13.

26. Ciancio SG. Drugs in dentistry. Chemical sterilizing agents: glutaraldehydes. Dent Manage. 1986; 26(11):76-7.

27. Cottone JA, Molinari JA. Selection for dental practice of chemical disinfectants and sterilants for hepatitis and AIDS. Aust Dent J. 1987; 32(5):368-74.

28. Council ODMIaE, Council ODP, Council ODT. Infection control recommendations for the dental office and the dental laboratory. J Am Dent Assoc. Chicago 1988; $116(2): 241-248$.

29. Council ODT, Council OPSaDLR. Guidelines for infection control in the dental office and the commercial dental laboratory. J Am Dent Assoc. Chicago 1985; 110:969-972.

30. Craig RG. Materiais dentarios : propriedades e manipulação. 3 ed. Rio de Janeiro: Guanabara; 1988.204.

31. Crawford JJ. State-of-the-art: practical infection control in dentistry. J Am Dent Assoc. 1985; 110(4):629-33.

32. Cucci AL, Vergani CE, Giampaolo ET, Afonso MC. Water sorption, solubility, and bond strength of two autopolymerizing acrylic resins and one heat-polymerizing acrylic resin. J Prosthet Dent. 1998; 80(4):434-8. 
33. DePaola LG, Minah GE, Elias SA, Eastwood GW, Walters RA. Clinical and microbial evaluation of treatment regimens to reduce denture stomatitis. Int $\mathbf{J}$ Prosthodont. 1990; 3(4):369-74.

34. Diaz-Arnold AM, Dunne JT, Jones AH. Microhardness of provisional fixed prosthodontic materials. J Prosthet Dent. 1999; 82(5):525-8.

35. Dills SS, Olshan AM, Goldner S, Brogdon C. Comparison of the antimicrobial capability of an abrasive paste and chemical-soak denture cleaners. J Prosthet Dent. 1988; 60(4):467-70.

36. Dogan A, Bek B, Cevik NN, Usanmaz A. The effect of preparation conditions of acrylic denture base materials on the level of residual monomer, mechanical properties and water absorption. J Dent. 1995; 23(5):313-8.

37. Engelhardt JP. The microbial decomposition of dental resins and its importance to the microbial balance of the oral cavity. Int Dent J. 1974; 24(3):376-86.

38. Frank RM, Steuer P. Transmission electron microscopy of plaque accumulations in denture stomatitis. J Prosthet Dent. 1985; 53(1):115-24.

39. Furukawa KK, Niagro FD, Runyan DA, Cameron SM. Effectiveness of chlorine dioxide in disinfection on two soft denture liners. J Prosthet Dent. 1998; 80(6):7239.

40. Gerhardt DE, Williams HN. Factors affecting the stability of sodium hypochlorite solutions used to disinfect dental impressions. Quintessence Int. 1991; 22(7):587-91.

41. Ghalichebaf M, Graser GN, Zander HA. The efficacy of denture-cleansing agents. J Prosthet Dent. 1982; 48(5):515-20.

42. Glass RT, Bullard JW, Conrad RS, Blewett EL. Evaluation of the sanitization effectiveness of a denture-cleaning product on dentures contaminated with known microbial flora. An in vitro study. Quintessence Int. 2004; 35(3):194-9.

43. Gornitsky M, Paradis II, Landaverde G, Malo AM, Velly AM. A clinical and microbiological evaluation of denture cleansers for geriatric patients in long-term care institutions. J Can Dent Assoc. 2002; 68(1):39-45. 
44. Harrison A, Huggett R. Effect of the curing cycle on residual monomer levels of acrylic resin denture base polymers. J Dent. 1992; 20(6):370-4.

45. Harrison Z, Johnson A, Douglas CW. An in vitro study into the effect of a limited range of denture cleaners on surface roughness and removal of Candida albicans from conventional heat-cured acrylic resin denture base material. J Oral Rehabil. 2004; 31(5):460-7.

46. Henderson CW, Schwartz RS, Herbold ET, Mayhew RB. Evaluation of the barrier system, an infection control system for the dental laboratory. J Prosthet Dent. 1987; 58(4):517-21.

47. Iacopino AM, Wathen WF. Oral candidal infection and denture stomatitis: a comprehensive review. J Am Dent Assoc. 1992; 123(1):46-51.

48. Jagger D, Harrison A, Vowles R, Jagger R. The effect of the addition of surface treated chopped and continuous poly (methyl methacrylate) fibres on some properties of acrylic resin. J Oral Rehabil. 2001; 28(9):865-72.

49. Kahn RC, Lancaster MV, Kate W, Jr. The microbiologic cross-contamination of dental prostheses. J Prosthet Dent. 1982; 47(5):556-9.

50. Katberg JJ. Cross-contamination via the prosthodonticlaboratory. J Prosthet Dent. $1974 ; 32: 412-419$.

51. Kedjarune U, Charoenworaluk N, Koontongkaew S. Release of methyl methacrylate from heat-cured and autopolymerized resins: cytotoxicity testing related to residual monomer. Aust Dent J. 1999; 44(1):25-30.

52. King AH, Matis B. Infection control of in-office dental laboratories. Dent Clin North Am. 1991; 35(2):415-26.

53. Kwon TY, Imai Y. Polymerization characteristics of ethyl methacrylate-based resin initiated by TBB. Dent Mater J. 2004; 23(2):161-5.

54. Lamb DJ, Ellis B, Priestley D. Loss into water of residual monomer from autopolymerizing dental acrylic resin. Biomaterials. 1982; 3(3):155-9. 
55. Lamfon H, Porter SR, McCullough M, Pratten J. Formation of Candida albicans biofilms on non-shedding oral surfaces. Eur J Oral Sci. 2003; 111(6):465-71.

56. Lee SY, Lai YL, Hsu TS. Influence of polymerization conditions on monomer elution and microhardness of autopolymerized polymethyl methacrylate resin. Eur J Oral Sci. 2002; 110(2):179-83.

57. Lin CT, Lee SY, Tsai TY, Dong DR, Shih YH. Degradation of repaired denture base materials in simulated oral fluid. J Oral Rehabil. 2000; 27(3):190-8.

58. Lin JJ, Cameron SM, Runyan DA, Craft DW. Disinfection of denture base acrylic resin. J Prosthet Dent. 1999; 81(2):202-6.

59. Lombardi T, Budtz-Jorgensen E. Treatment of denture-induced stomatitis: a review. Eur J Prosthodont Restor Dent. 1993; 2(1):17-22.

60. Loney RW, Moulding MB. The effect of finishing and polishing on surface roughness of a processed resilient denture liner. Int J Prosthodont. 1993; 6(4):390-6.

61. Loney RW, Moulding MB, Hacker CH, Ritsco RG. Finishing and polishing of a poly (fluoroalkoxyphosphazene) resilient denture liner. Int J Prosthodont. 1994; 7(4):362-7.

62. Ma T, Johnson GH, Gordon GE. Effects of chemical disinfectants on the surface characteristics and color of denture resins. J Prosthet Dent. 1997; 77(2):197-204.

63. MacCallum M, Stafford GD, MacCulloch WT, Combe EC. Which cleanser? A report on a survey of denture cleansing routine and the development of a new denture cleanser. Dent Pract Dent Rec. 1968; 19(3):83-9.

64. Mc Donnell G, Russel AD. Antiseptics and desinfectants: activity, action and resistance. Clin Microbiol Rev. Washington 1999; 12(1):147-179.

65. McGowan MJ, Shimoda LM, Woolsey GD. Effects of sodium hypochlorite on denture base metals during immersion for short-term sterilization. J Prosthet Dent. $1988 ; 60(2): 212-8$. 
66. Merchant VA. An update on infection control in the dental laboratory. Quintess Dent Technol. Lombard 1997:157-169.

67. Merchant VA, Molinari JA. Infection control in prosthodontics: a choice no longer. Gen Dent. 1989; 37(1):29-32.

68. Minagi S, Tsunoda T, Yoshida K, Tsuru H. Objective testing of the efficiency of denture-cleansing agents. J Prosthet Dent. 1987; 58(5):595-8.

69. Molinari JA, Gleason MJ, Cottone JA, Barrett ED. Cleaning and disinfectant properties of dental surface disinfectants. J Am Dent Assoc. 1988; 117(1):179-82.

70. Molinari JA, Merchant VA, Gleason MJ. Controversies in infection control. Dent Clin North Am. 1990; 34(1):55-69.

71. Molinari JA, Runnells RR. Role of disinfectants in infection control. Dent Clin North Am. 1991; 35(2):323-37.

72. Molinari JA, Schaefer ME, Runnells RR. Pratical infection control in Dentistry. 1 ed. Baltimore: Williams \& Wilkins; 1996.161-175.

73. Moore TC, Smith DE, Kenny GE. Sanitization of dentures by several denture hygiene methods. J Prosthet Dent. 1984; 52(2):158-63.

74. Neppelenbroek KH, Pavarina AC, Vergani CE, Giampaolo ET. Hardness of heatpolymerized acrylic resins after disinfection and long-term water immersion. $\mathrm{J}$ Prosthet Dent. 2005; 93(2):171-6.

75. Nikawa H, Chen J, Hamada T, Nishimura M, Polyzois G. Candida albicans colonization on thermal cycled maxillofacial polymeric materials in vitro. J Oral Rehabil. 2001; 28(6):526-33.

76. Nikawa H, Hamada T, Yamamoto T. Denture plaque--past and recent concerns. J Dent. 1998; 26(4):299-304.

77. O'Brien WJ. Dental materials and their selection 2ed. Chicago: Quintessence Pub. Co.; 1997.421. 
78. Odman PA. The effectiveness of an enzyme-containing denture cleanser. Quintessence Int. 1992; 23(3):187-90.

79. Orsi IA, Andrade VG. Effect of chemical disinfectants on the transverse strength of heat-polymerized acrylic resins submitted to mechanical and chemical polishing. $\mathrm{J}$ Prosthet Dent. 2004; 92(4):382-8.

80. Pavarina AC, Machado AL, Giampaolo ET, Vergani CE. Effects of chemical disinfectants on the transverse strength of denture base acrylic resins. J Oral Rehabil. 2003; 30(11):1085-9.

81. Pavarina AC, Pizzolitto AC, Machado AL, Vergani CE, Giampaolo ET. An infection control protocol: effectiveness of immersion solutions to reduce the microbial growth on dental prostheses. J Oral Rehabil. 2003; 30(5):532-6.

82. Pavarina AC, Vergani CE, Machado AL, Giampaolo ET, Teraoka MT. The effect of disinfectant solutions on the hardness of acrylic resin denture teeth. J Oral Rehabil. 2003; 30(7):749-52.

83. Phillips RW. Phillips materias dentários 11 ed. Rio de Janeiro: Elsevier; 2005.764.

84. Pires FR, Santos EB, Bonan PR, De Almeida OP, Lopes MA. Denture stomatitis and salivary Candida in Brazilian edentulous patients. J Oral Rehabil. 2002; 29(11):1115-9.

85. Polyzois GL, Zissis AJ, Yannikakis SA. The effect of glutaraldehyde and microwave disinfection on some properties of acrylic denture resin. Int $\mathbf{J}$ Prosthodont. 1995; 8(2):150-4.

86. Powell GL, Runnells RD, Saxon BA, Whisenant BK. The presence and identification of organisms transmitted to dental laboratories. J Prosthet Dent. 1990; 64(2):235-7.

87. Quirynen M, Marechal M, Busscher HJ, Weerkamp AH, Darius PL, van Steenberghe D. The influence of surface free energy and surface roughness on early plaque formation. An in vivo study in man. J Clin Periodontol. 1990; 17(3):138-44. 
88. Radford DR, Challacombe SJ, Walter JD. Denture plaque and adherence of Candida albicans to denture-base materials in vivo and in vitro. Crit Rev Oral Biol Med. 1999; 10(1):99-116.

89. Radford DR, Sweet SP, Challacombe SJ, Walter JD. Adherence of Candida albicans to denture-base materials with different surface finishes. J Dent. 1998; 26(7):577-83.

90. Rudd RW, Senia ES, McCleskey FK, Adams ED, Jr. Sterilization of complete dentures with sodium hypochlorite. J Prosthet Dent. 1984; 51(3):318-21.

91. Rutala WA. APIC guideline for selection and use of disinfectants. 1994, 1995, and 1996 APIC Guidelines Committee. Association for Professionals in Infection Control and Epidemiology, Inc. Am J Infect Control. 1996; 24(4):313-42.

92. Rutala WA, Weber DJ. Uses of inorganic hypochlorite (bleach) in health-care facilities. Clin Microbiol Rev. 1997; 10(4):597-610.

93. Sadamori S, Kotani H, Hamada T. The usage period of dentures and their residual monomer contents. J Prosthet Dent. 1992; 68(2):374-6.

94. Samaranayake LP, McCourtie J, MacFarlane TW. Factors affecting th in-vitro adherence of Candida albicans to acrylic surfaces. Arch Oral Biol. 1980; 25(89):611-5.

95. Saunders TR, Guillory VL, Gregoire ST, Pimsler M, Mitchell MS. The effect of bioburden on in-depth disinfection of denture base acrylic resin. J Calif Dent Assoc. 1998; 26(11):846-50.

96. Sears V. Developments in the denture field during the past half-century. . J Prosthet Dent. St. Louis 1958; 8(1):61-70.

97. Shen C, Javid NS, Colaizzi FA. The effect of glutaraldehyde base disinfectants on denture base resins. J Prosthet Dent. 1989; 61(5):583-9.

98. Sofou A, Emmanouil J, Peutzfeldt A, Owall B. The effect of different polishing techniques on the surface roughness of acrylic resin materials. Eur J Prosthodont Restor Dent. 2001; 9(3-4):117-22. 
99. Suzuki S. In vitro wear of nano-composite denture teeth. J Prosthodont. 2004; 13(4):238-43.

100. Takahashi Y, Chai J, Kawaguchi M. Effect of water sorption on the resistance to plastic deformation of a denture base material relined with four different denture reline materials. Int J Prosthodont. 1998; 11(1):49-54.

101. Takahashi Y, Chai J, Kawaguchi M. Equilibrium strengths of denture polymers subjected to long-term water immersion. Int J Prosthodont. 1999; 12(4):348-52.

102. Teughels W, Van Assche N, Sliepen I, Quirynen M. Effect of material characteristics and/or surface topography on biofilm development. Clin Oral Implants Res. 2006; 17 Suppl 2:68-81.

103. Theilade E, Budtz-Jorgensen E, Theilade J. Predominant cultivable microflora of plaque on removable dentures in patients with healthy oral mucosa. Arch Oral Biol. 1983; 28(8):675-80.

104. Theilade J, Budtz-Jorgensen E. Electron microscopic study of denture plaque. J Biol Buccale. 1980; 8(4):287-97.

105. Ulusoy M, Ulusoy N, Aydin AK. An evaluation of polishing techniques on surface roughness of acrylic resins. J Prosthet Dent. 1986; 56(1):107-12.

106. Vallittu PK. The effect of surface treatment of denture acrylic resin on the residual monomer content and its release into water. Acta Odontol Scand. 1996; 54(3):18892.

107. Verran J, Maryan CJ. Retention of Candida albicans on acrylic resin and silicone of different surface topography. J Prosthet Dent. 1997; 77(5):535-9.

108. Wakefield CW. Laboratory contamination of dental prostheses. J Prosthet Dent. 1980; 44(2):143-6.

109. Weaver RE, Goebel WM. Reactions to acrylic resin dental prostheses. J Prosthet Dent. 1980; 43(2):138-42. 
110. Webb BC, Thomas CJ, Harty DW, Willcox MD. Effectiveness of two methods of denture sterilization. J Oral Rehabil. 1998; 25(6):416-23.

111. Whitacre RJ. Environmental barriers in dental office infection control. Dent Clin North Am. 1991; 35(2):367-81.

112. Whitman DJ, McKinney JE, Hinman RW, Hesby RA, Pelleu GB, Jr. In vitro wear rates of three types of commercial denture tooth materials. J Prosthet Dent. 1987; 57(2):243-6.

113. Williams HN, Falkler WA, Jr., Hasler JF, Libonati JP. The recovery and significance of nonoral opportunistic pathogenic bacteria in dental laboratory pumice. J Prosthet Dent. 1985; 54(5):725-30.

114. Wood PR. Cross infection control in dentistry. A pratical illustrated guide. 1 ed. London: Mosby; 1992.

115. Yamauchi M, Yamamoto K, Wakabayashi M, Kawano J. In vitro adherence of microorganisms to denture base resin with different surface texture. Dent Mater J. 1990; 9(1):19-24.

116. Yilmaz H, Aydin C, Bal BT, Ozcelik B. Effects of disinfectants on resilient denture-lining materials contaminated with Staphylococcus aureus, Streptococcus sobrinus, and Candida albicans. Quintessence Int. 2005; 36(5):373-81.

117. Yiu CK, King NM, Pashley DH, Suh BI, Carvalho RM, Carrilho MR, et al. Effect of resin hydrophilicity and water storage on resin strength. Biomaterials. 2004; 25(26):5789-96.

118. Zissis AJ, Polyzois GL, Yannikakis SA, Harrison A. Roughness of denture materials: a comparative study. Int J Prosthodont. 2000; 13(2):136-40. 